
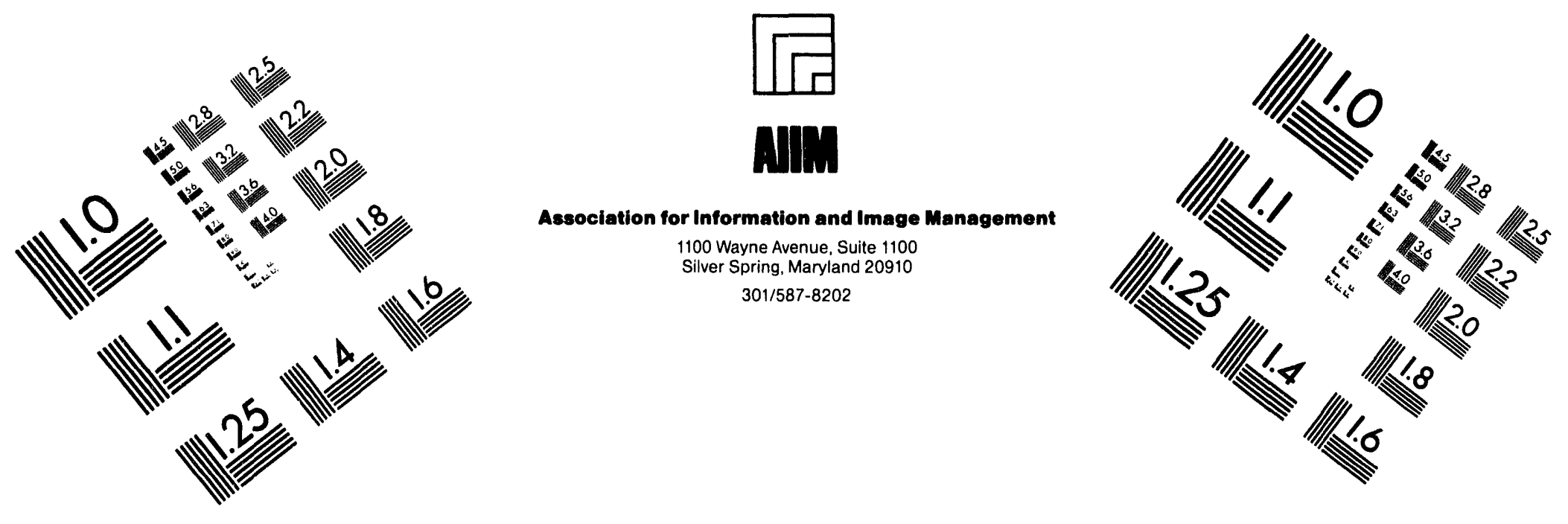

\title{
Centimeter
}

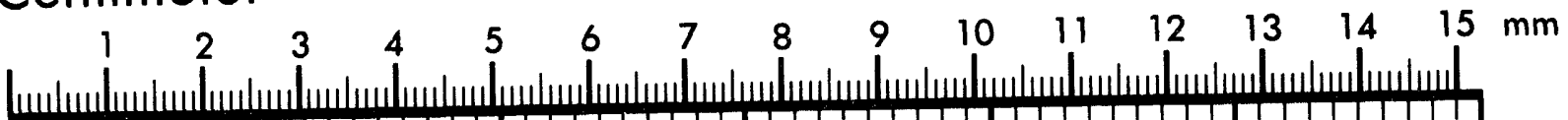

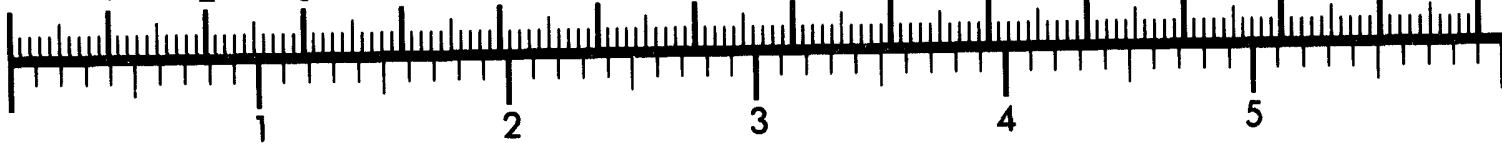
Inches
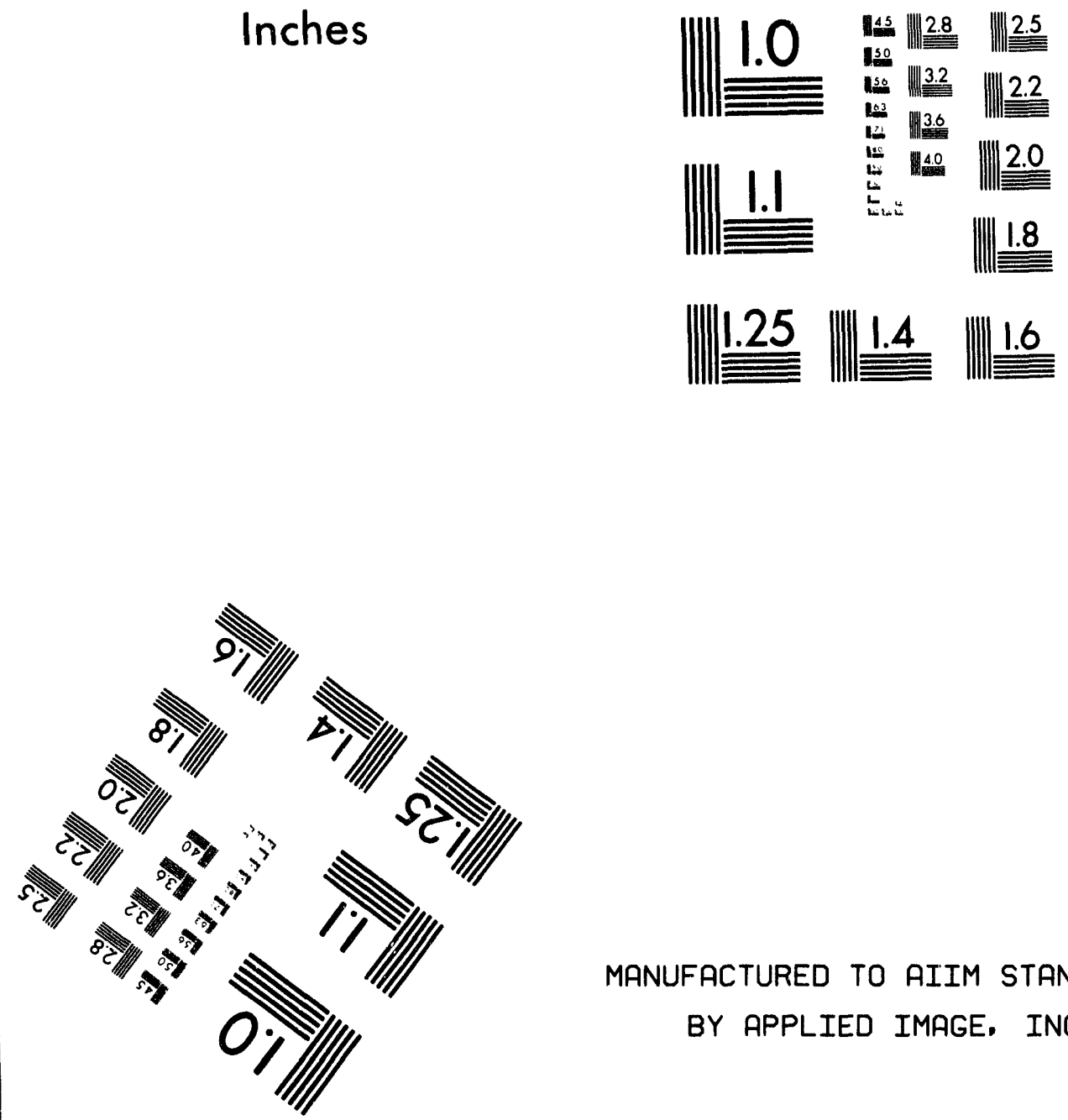

MANUFACTURED TO AIIM STANDARDS

BY APPLIED IMAGE. INC.

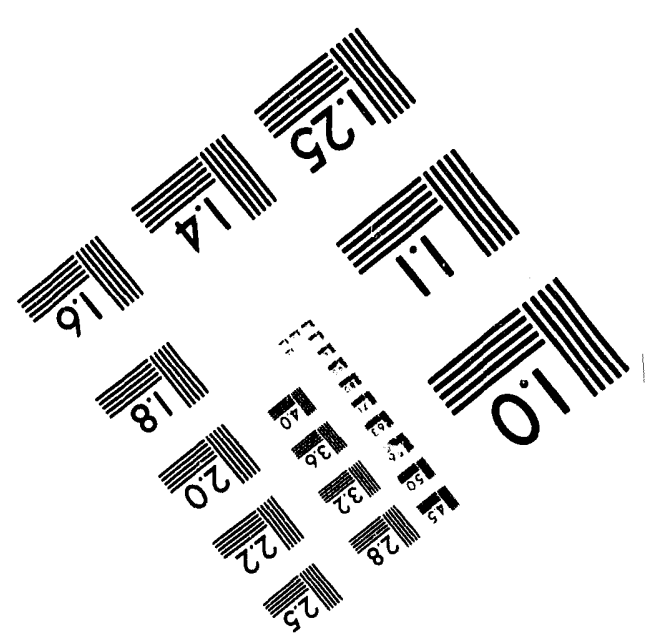



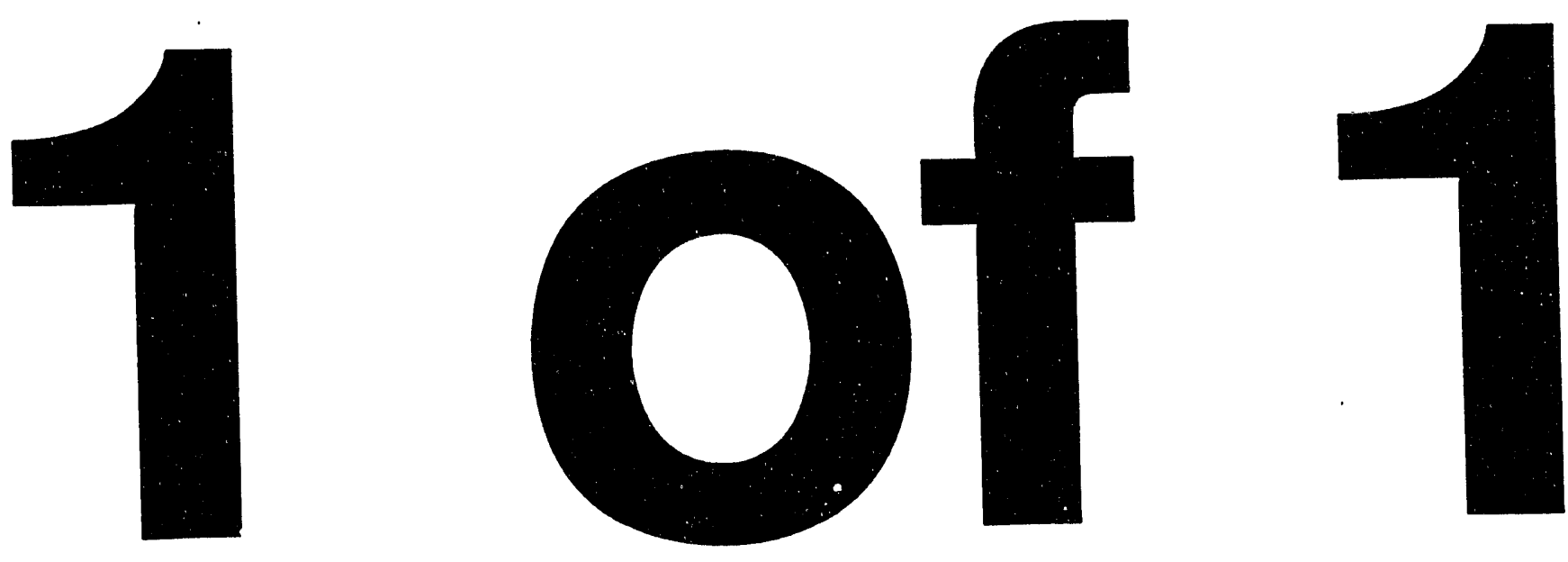


\title{
Study of Cesium Volatility from Sodium Carbonate Based Melts
}

\author{
Bartley B. Ebbinghaus \\ Oscar H. Krikorian \\ Martyn G. Adamson \\ Dennis L. Fleming
}

\section{December 1993}

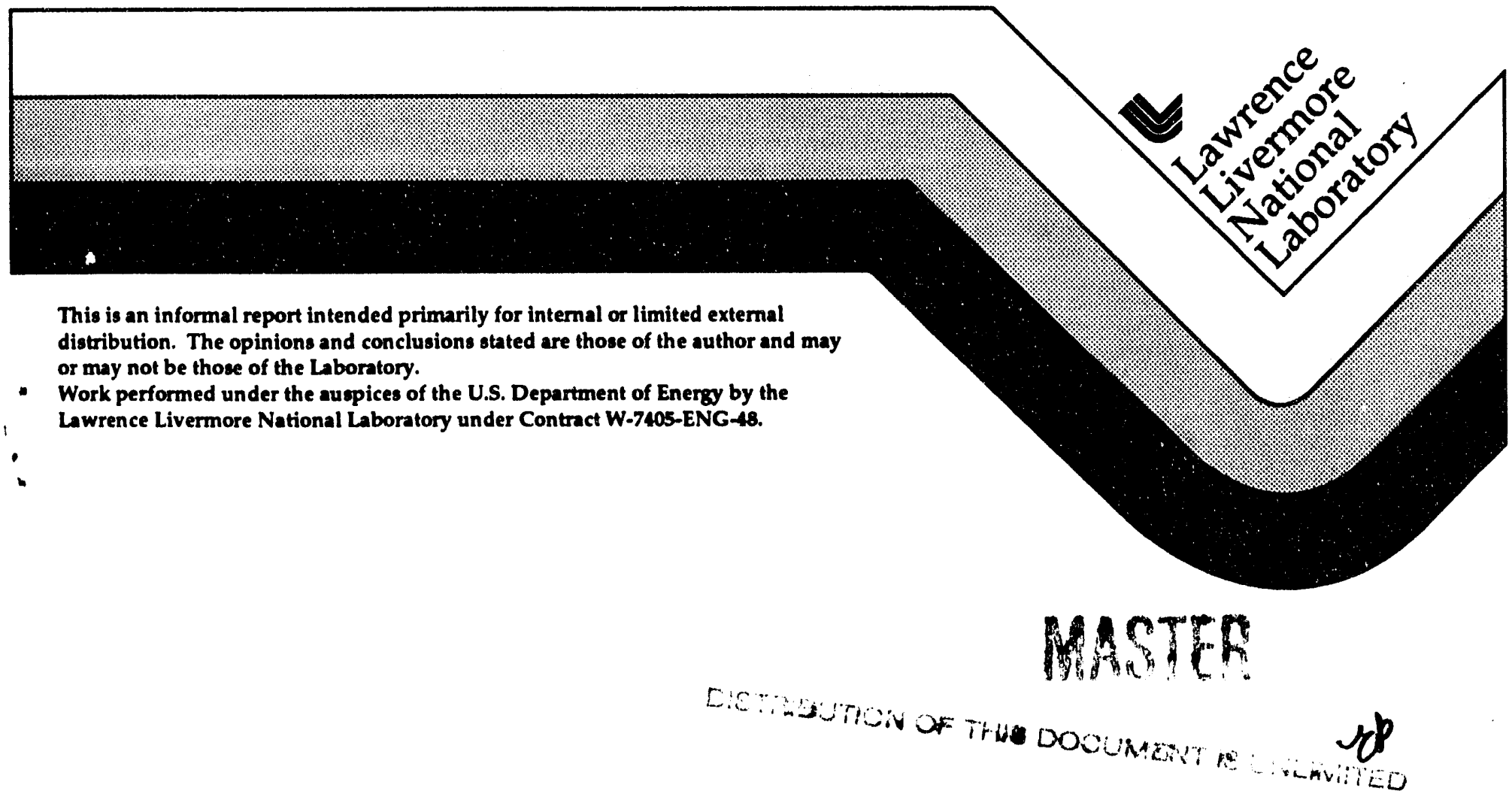




\section{DISCLAIMER}

This document was prepared as an account of work sponeored by an ageacy of the United States Government. Neither the United States Government sor the Univeratty of Calirnraia nor any of their employees, makeas any warranty, express or buplied, or assumes any legal liability or responsiblitty for the sceuracy, completeness, or usefulaess of anj information, apparatus, product, or procese disclosed, or represents that its use would not infringe privately ouned rights. Reference hertin to any specific commerdis products, proceses, or service by trade anme, trademark, manufacturer, or otherwise, does not neceasarily cosetitute or inply its cadoraement, recommendation, or favoring by the United States Goverament or the Ualverathy of Callfornia. The views and opinions of authors expresied herein do not necessarily state or reflect those of the United States Government or the University of California, and shall not be used for advertising or product endorsement purposes.

This report has been reproduced directly from the best available copy.

Available to DOE and DOE contractors from the Omice of Scientific and Technical Information

P.O. Box 62, Oak Ridge, TN 37831

Prices available from (615) 576-8401, FTS 626-8401

Available to the public from the

National Technical Information Service

US. Department of Commerce

5285 Port Royal Rd.

Springfield, VA 22161 
Study of Cesium Volatility from Sodium Carbonate Based Melts

Bartley B. Ebbinghaus

Oscar H. Krikorian

Martyn G. Adamson

Dennis L. Fleming

Lawrence Livermore National Laboratory

Livermore, CA 94551 
Table of Contents

Abstract 1

Introduction 2

Background Studies $\quad 4$

Vapor Species above $\mathrm{Cs}_{2} \mathrm{CO}_{3}(\mathrm{l})$ and $\mathrm{CsCl}(\mathrm{l})$

Calculated Activity Coefficients in Various Salt Systems 7

$\begin{array}{ll}\text { Experimental } & 10\end{array}$

$\begin{array}{ll}\text { Transpiration Method } & 10\end{array}$

$\begin{array}{ll}\text { Description of Transpiration Equipment } & 11\end{array}$

$\begin{array}{ll}\text { Collection Tube Analysis } & 16\end{array}$

$\begin{array}{ll}\text { Starting Materials } & 16\end{array}$

Preparation and Characterization of Sample Materials 16

A.nalysis of Results $\quad 19$

$\begin{array}{ll}\text { Water Vapor Effect } & 19\end{array}$

$\begin{array}{lr}\text { Horizontal versus Vertical Configuration } & 19\end{array}$

$\begin{array}{ll}\text { Concentration Effect } & 25\end{array}$

$\begin{array}{lr}\text { Sulfate Effect } & 25\end{array}$

$\begin{array}{ll}\text { Chloride Effect } & 31\end{array}$

$\begin{array}{ll}\text { Ash Effect } & 31\end{array}$ 
Thermodynamic Parameters 34

Standard Entropy of $\mathrm{Cs}_{2} \mathrm{CO}_{3}(\mathrm{~s}) \quad 34$

$\begin{array}{ll}\text { Activity Coefficients } & 36\end{array}$

Application to Molten Salt Oxidation 41

$\mathrm{CsCl}(\mathrm{g})$ versus $\mathrm{CsOH}(\mathrm{g})$ Cross-over Chloride Concentration 41

Calculation of Percent Retention 41

Application to the Rockwell MSO Process 44

$\begin{array}{ll}\text { Summary and Conclusions } & 47\end{array}$

Acknowledgements 48

References $\quad 49$ 
Study of Cesium Volatility from Sodium Carbonate Based Melts

\author{
Bartley B. Ebbinghaus \\ Oscar H. Krikorian \\ Martyn G. Adamson \\ Dennis L. Fleming
}

Lawrence Livermore National Laboratory

Livermore, CA 94551

\title{
Abstract
}

The purpose of this study was to obtain thermodynamic data on cesium volatility from sodium carbonate based molten salts for application to the Rockwell-ETEC molten salt oxidation process. At temperatures ranging from 1073 to $1373 \mathrm{~K}$, volatility tests were conducted on a horizontal and a vertical transpiration apparatus using a carrier gas composed of $\mathrm{CO}_{2}(\mathrm{~g})$ and $\mathrm{H}_{2} \mathrm{O}(\mathrm{g})$ which was passed over or bubbled through a sodium carbonate bath containing cesium carbonate and various additives. The major vapor species was identified to be $\mathrm{CsOH}(\mathrm{g})$ except when greater than $3 \%$ chloride is present in the melt, then the major vapor species is $\mathrm{CsCl}(\mathrm{g})$. The decrease in volatility of cesium as a function of cesium concentration in $\mathrm{Cs}_{2} \mathrm{CO}_{3}-\mathrm{Na}_{2} \mathrm{CO}_{3}$ mixtures follows Raoult's law very closely. Thus, this system exhibits close to ideal solution behavior. The addition of $22.5 \mathrm{wt} \%$ sodium sulfate decreases the cesium volatility by just under a factor of 2 , and the addition of $10.0 \mathrm{wt} \%$ sodium chloride increases the cesium volatility about an order of magnitude. The addition of $2.0 \mathrm{wt} \%$ ash, molecular sieve, or silica show little or no effect. However, the data indicate that higher concentrations of ash will decrease the cesium volatility. For the addition of $22.5 \mathrm{wt} \%$ sodium sulfate the activity coefficient, $\gamma\left(\mathrm{Cs}_{2} \mathrm{CO}_{3}\right)^{1 / 2}$, is calculated to be $0.720 \pm 0.068$, and for the addition of $10.0 \mathrm{wt} \%$ sodium chloride, the activity coefficient, $\gamma(\mathrm{CsCl})$, is calculated to be $8.118 \pm 2.317$. Assuming that Henry's law applies, these activity coefficients are used to extrapolate the effect on cesium retention in the molten salt oxidizer of sulfate and chloride at lower cesium concentrations. 


\section{Introduction}

This study has been performed in support of the Rockwell-ETEC molten salt oxidation process. In the Rockwell process, a combustible waste material is fed along with excess air into a salt bath composed primarily of sodium carbonate which is typically kept between 1150 and $1250 \mathrm{~K}$. This oxidizes the waste material to yield primarily carbon dioxide, water vapor, and an ash residue which is wetted and retained by the melt. Except for carryover due to volatility, physical entrainment, or splashing, any hazardous metals, actinides, and fission products in the waste feed are held up and retained by the melt.

During the fall of 1992, Rockwell-ETEC tested the molten salt oxidation process by destroying 50 gallons of radioactively contaminated oil [1]. As well as actinides and other fission products, the oils contained radioactive cesium, $137 \mathrm{Cs}$, which is a major fission product of both uranium and plutonium and has a half-life of about 30 years. Rockwell's data from the oil processing indicated that only 53\% of the radioactive cesium was retained in the melt when a sodium carbonate bath was used and only $85 \%$ of the radioactive cesium was retained in the melt when a bath mixture of sodium carbonate and sodium sulfate was used. Previous work with non-radioactive cesium [2] showed much greater cesium retention in the molten salt oxidizer, i.e. greater than $99.5 \%$. The cesium in the waste feed was present as cesium nitrate and the waste feed was composed of a mixture of approximately 50wt\% paper, 8wt\% PVC, 32wt\% polyethylene, and $10 \mathrm{wt} \%$ rubber. The reason for the large discrepancy between Rockwell's older and more recent data is unknown. In the earlier work, 16 wt\% ash was present in the carbonate melt which may have interacted with the cesium and reduced its volatility. Earlier work was also conducted at lower temperatures, about $1153 \mathrm{~K}$, whereas more recent work was conducted at higher temperatures, about $1198 \mathrm{~K}$.

The goal of this study has been to provide cesium volatility data from molten carbonate based salts under a variety of conditions such that the effects of operating conditions on cesium retention in the molten salt oxidizer can be better understood. In this work, the major cesium vapor species have been identified, and the effects of cesium concentration and additives (sulfate, chloride, and ash) on cesium volatility have been measured. 
Table 1. Thermodynamic functions for $\mathrm{Cs}_{2} \mathrm{CO}_{3}(s, 1)$.

$$
\begin{aligned}
& \mathrm{S}^{\circ} 298=212.73 \pm 1.42 \mathrm{~J} / \mathrm{mol}-\mathrm{K} \\
& \Delta \mathrm{H}^{\circ} \mathrm{f}, 298=-1134.93 \pm 0.63 \mathrm{~kJ} / \mathrm{mol} \\
& \mathrm{S}^{\circ} \text { fus, } 1061=46.370 \mathrm{~J} / \mathrm{mol}-\mathrm{K} \\
& \Delta \mathrm{H}^{\circ}{ }^{\circ} \text { fus, } 1061=49.199 \mathrm{~kJ} / \mathrm{mol}
\end{aligned}
$$

\begin{tabular}{lcccc}
$\begin{array}{l}\mathbf{T} \\
(\mathbf{K})\end{array}$ & $\begin{array}{c}\mathrm{C}_{\mathbf{p}} \\
(\mathrm{J} / \mathrm{mol}-\mathbf{K})\end{array}$ & $\begin{array}{c}\mathbf{S}^{\circ} \mathbf{T} \\
(\mathrm{J} / \mathrm{mol}-\mathbf{K})\end{array}$ & $\begin{array}{c}-\left(\mathbf{G}^{\circ} \mathbf{T}-\mathbf{H}^{\circ} 298\right) / \mathbf{T} \\
(\mathrm{J} / \mathbf{m o l}-\mathbf{K})\end{array}$ & $\begin{array}{l}\mathbf{H}^{\circ} \mathbf{T}-\mathbf{H}^{\circ} 298 \\
(\mathbf{K J} / \mathbf{m o l})\end{array}$ \\
\hline & & & & \\
298.15 & 123.830 & 212.732 & 212.732 & 0.000 \\
300 & 124.110 & 213.499 & 212.734 & 0.229 \\
400 & 136.371 & 250.992 & 217.764 & 13.291 \\
500 & 145.771 & 282.463 & 227.638 & 27.412 \\
600 & 154.043 & 309.782 & 239.101 & 42.409 \\
700 & 161.784 & 334.124 & 250.966 & 58.203 \\
800 & 169.241 & 356.207 & 262.761 & 74.756 \\
900 & 176.534 & 376.563 & 274.289 & 92.046 \\
1000 & 183.724 & 395.535 & 285.475 & 110.060 \\
$1061(\mathrm{~s})$ & 188.360 & 406.541 & 292.120 & 121.400 \\
$1061(1)$ & 195.138 & 452.911 & 292.120 & 170.599 \\
1100 & 195.138 & 459.955 & 297.947 & 178.209 \\
1200 & 195.138 & 476.934 & 312.165 & 197.723 \\
1300 & 195.138 & 492.554 & 325.449 & 217.237 \\
1400 & 195.138 & 507.015 & 337.907 & 236.751 \\
1500 & 195.138 & 520.478 & 349.635 & 256.265 \\
1600 & 195.138 & 533.072 & 360.711 & 275.778 \\
1700 & 195.138 & 544.903 & 371.201 & 295.292 \\
1800 & 195.138 & 556.056 & 381.164 & 314.806 \\
1900 & 195.138 & 566.607 & 390.649 & 334.320 \\
2000 & 195.138 & 576.616 & 399.699 & 353.834
\end{tabular}




\section{Background Studies}

\section{Vapor Species above $\mathrm{Cs}_{2} \mathrm{CO}_{2}(\mathrm{ll}$ and $\mathrm{CsCl(l)}$ :}

A considerable amount of thermodynamic data are already available for cesium compounds and vapor species which might be important in the molten salt oxidation process. Data for $\mathrm{Cs}(\mathrm{g}), \mathrm{Cs} 2(\mathrm{~g}), \mathrm{Cs}_{2} \mathrm{O}(\mathrm{g}), \mathrm{CsO}(\mathrm{g})$, $\mathrm{Cs}_{2} \mathrm{O}_{2}(\mathrm{~g}), \mathrm{CsOH}(\mathrm{g})$, and $\mathrm{Cs}_{2}(\mathrm{OH})_{2}(\mathrm{~g})$ are given by Cordfunke and Konings [3], data for $\mathrm{CsO}_{2}(\mathrm{~g})$ are given by Lamoreaux and Hildebrand [4], and data for $\mathrm{CsCl}(\mathrm{l}), \mathrm{CsCl}(\mathrm{g})$ and $\mathrm{Cs}_{2} \mathrm{Cl}_{2}(\mathrm{~g})$, are given in the JANAF tables [5]. However, thermodynamic data for cesium carbonate, $\mathrm{Cs}_{2} \mathrm{CO}_{3}(\mathrm{~s}, 1)$, are limited. The heat capacity of the solid is given by Barin [6], the $\Delta \mathrm{H}^{\circ} \mathrm{f}, 298$ value is given by Johnson and Gayer [7], and the $S^{\circ} 298$ value is determined from volatility data given later in this study. The enthalpy of fusion, $\Delta H^{\circ}$ fus, is given by Kobayasi, et al. [8]. They also give the melting point as $1061 \mathrm{~K}$. A best estimate for the heat capacity of the liquid was made by averaging available heat capacities for all the molten alkali carbonate and sulfate salts [5,6]. The resulting thermodynamic functions, $C_{p}, S^{\circ} T,-\left(G^{\circ} T-\right.$ $\left.\mathrm{H}^{\circ} 298\right) / \mathrm{T}$, and $\mathrm{H}^{\circ} \mathrm{T}-\mathrm{H}^{\circ} 298$, calculated for $\mathrm{Cs}_{2} \mathrm{CO}_{3}(\mathrm{~s}, 1)$ are given in Table 1 .

From these data, the vapor species above $\mathrm{Cs}_{2} \mathrm{CO}_{3}(1)$ and $\mathrm{CsCl}(1)$ can be calculated. To approximate conditions present in the molten salt oxidizer, $p\left(\mathrm{O}_{2}\right)$ and $\mathrm{p}\left(\mathrm{H}_{2} \mathrm{O}\right)$ are each taken to be $0.10 \mathrm{~atm}$. The logarithm of the vapor pressures of the various elemental, oxide, and hydroxide species above $\mathrm{Cs}_{2} \mathrm{CO}_{3}(\mathrm{l})$ are given in Figure 1. Clearly, $\mathrm{CsOH}(\mathrm{g})$ is the major vapor species followed by $\mathrm{Cs}_{2}(\mathrm{OH}) 2(\mathrm{~g})$. The logarithm of the vapor pressure of the chloride species above $\mathrm{CsCl}(\mathrm{l})$ are given in Figure 2. For comparison, the hydroxide species formed above $\mathrm{Cs}_{2} \mathrm{CO}_{3}(\mathrm{l})$ are also shown. Here, $\mathrm{CsCl}(\mathrm{g})$ is the major chloride vapor species. In addition, the vapor pressure of $\mathrm{CsCl}(\mathrm{g})$ above $\mathrm{CsCl}(\mathrm{l})$ is about an order of magnitude greater than the vapor pressure of $\mathrm{CsOH}_{(\mathrm{g})}$ above $\mathrm{Cs}_{2} \mathrm{CO}_{3}(\mathrm{l})$. Thus, the thermodynamic data indicate that $\mathrm{CsOH}(\mathrm{g})$ is the major vapor species in the molten salt oxidizer except when sufficient chloride is present, then $\operatorname{CsCl}(\mathrm{g})$ is the major vapor species. 
u

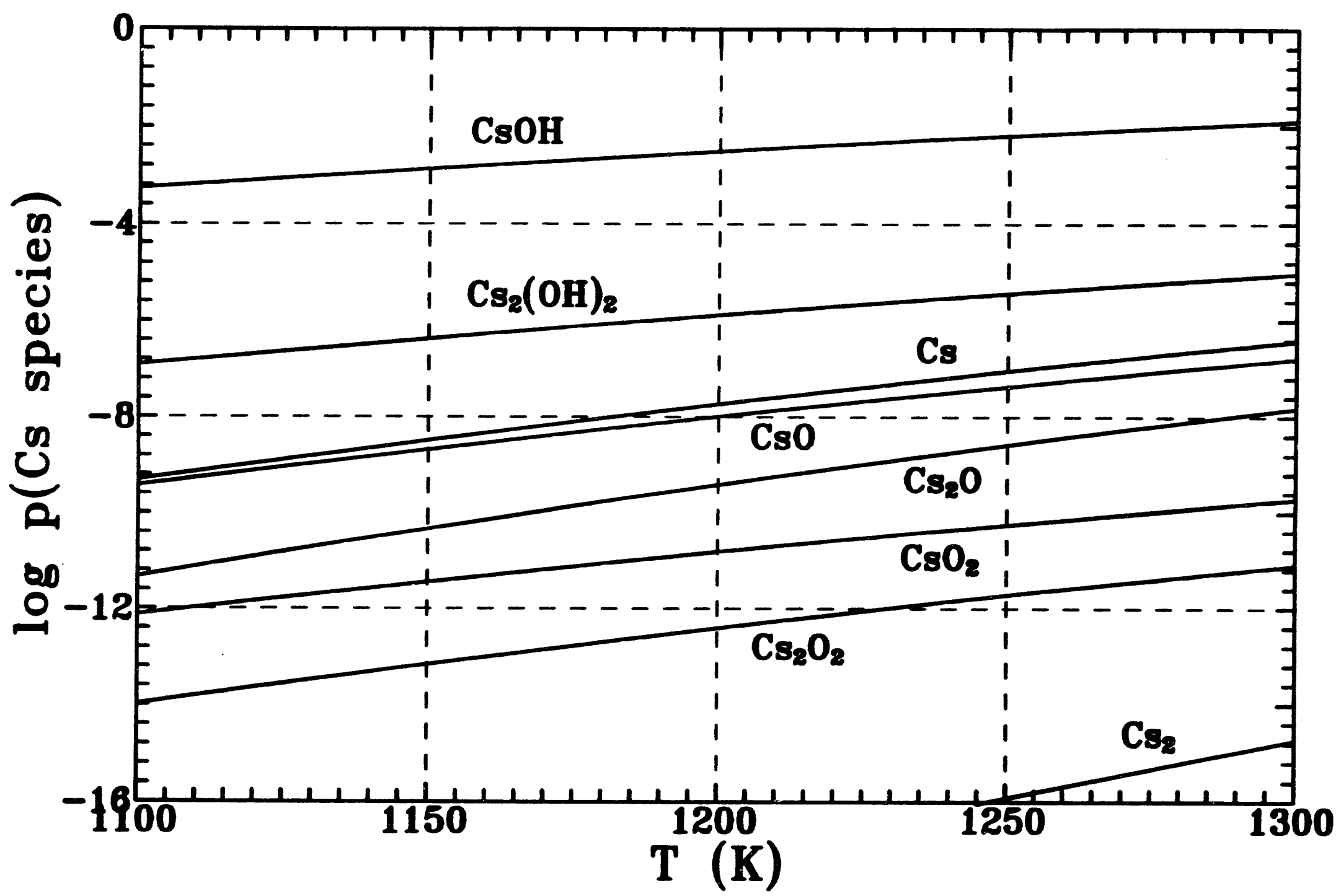

Figure 1. Plot showing the logarithm of the elemental, oxide, and hydroxide species vapor pressures formed above $\mathrm{Cs}_{2} \mathrm{CO}_{3}(1)$ as a function of temperature with $p\left(\mathrm{O}_{2}\right), p\left(\mathrm{H}_{2} \mathrm{O}\right)$, and $p\left(\mathrm{CO}_{2}\right)$ each at $0.10 \mathrm{~atm}$. 


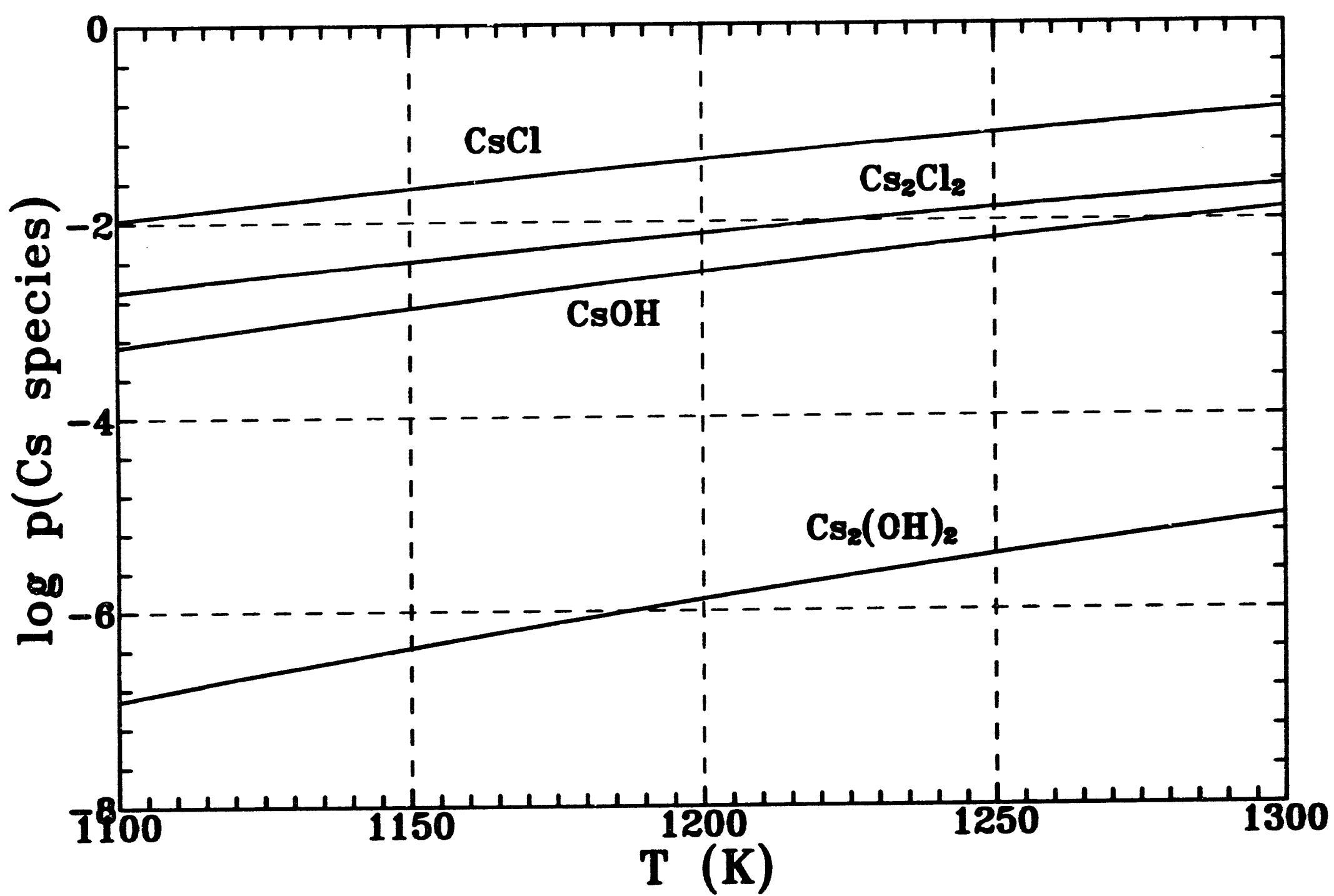

Figure 2. Plot showing the logarithm of the chloride species vapor pressures formed above $\mathrm{CsCl}(1)$ and the logarithm of the hydroxide species vapor pressures formed above $\mathrm{Cs}_{2} \mathrm{CO}_{3}(1)$ as a function of temperature with $\mathrm{p}\left(\mathrm{O}_{2}\right), \mathrm{p}\left(\mathrm{H}_{2} \mathrm{O}\right)$, and $\mathrm{p}\left(\mathrm{CO}_{2}\right)$ each at $0.10 \mathrm{~atm}$. 


\section{Calculated Activity Coefficients in Various Salt Systems:}

Since cesium will be present in the carbonate bath as a solution in sodium carbonate, the activity of the cesium salt, $\mathrm{Cs}_{2} \mathrm{CO}_{3}, \mathrm{Cs}_{2} \mathrm{SO}_{4}$, or $\mathrm{CsCl}$, is needed to calculate its volatility. The activity of the cesium salt is given by

$$
\begin{aligned}
& a\left(\mathrm{Cs}_{2} \mathrm{CO}_{3}\right)=\gamma\left(\mathrm{Cs}_{2} \mathrm{CO}_{3}\right) y^{+}\left(\mathrm{Cs}^{+}\right)^{2} y^{-}\left(\mathrm{CO}_{3}^{2-}\right), \\
& a\left(\mathrm{Cs}_{2} \mathrm{SO}_{4}\right)=\gamma\left(\mathrm{Cs}_{2} \mathrm{SO}_{4}\right) y^{+}\left(\mathrm{Cs}^{+}\right)^{2} y^{-}\left(\mathrm{SO}_{4}^{2-}\right),
\end{aligned}
$$

or

$$
\mathrm{a}(\mathrm{CsCl})=\gamma(\mathrm{CsCl}) y^{+}\left(\mathrm{Cs}^{+}\right) \mathrm{y}^{-}\left(\mathrm{Cl}^{-}\right)
$$

where $\mathrm{y}^{+}\left(\mathrm{Cs}^{+}\right)$is the cation equivalent fraction of cesium and $\mathrm{y}^{-}\left(\mathrm{CO}_{3}{ }^{2-}\right)$, $\mathrm{y}^{-}\left(\mathrm{SO}_{4}{ }^{-}\right)$, and $\mathrm{y}^{-}\left(\mathrm{Cl}^{-}\right)$are the anion equivalent fractions of carbonate, sulfate, and chloride. The cation equivalent fraction of component $A$ in a binary salt system is defined as

$$
y^{+}(A)=q(A) x+(A) /[q(A) x+(A)+q(B) x+(B)]
$$

where $x^{+}(A)$ and $x^{+}(B)$ are the cation mole fractions of substances $A$ and $B$, and $q(A)$ and $q(B)$ are the ionic charges of $A$ and $B$. If the charges are the same, then the equivalent fraction equals the mole fraction. If $y^{-}$and $x^{-}$ are substituted for $y^{+}$and $x^{+}$, the same equation defines the anion equivalent fraction. The cation mole fraction of component $A$ is defined as

$$
x^{+}\left(A^{+}\right)=N(A) /[N(A)+N(B)]
$$

where $N(A)$ is the number of moles of cation $A$ and $N(B)$ is the number of moles of cation B. The anion mole fraction is defined in a similar manner. The reason that the activities of the salts are related to the product of the cation and anion equivalent fractions in the molten salt rather than the product of the cation and anion mole fractions is a result of the fact that vacancies are associated with anions or cations of greater charge in order to maintain charge neutrality. In an $\mathrm{NaCl}$ crystal lattice, for example, one $\mathrm{Ca}^{2+}$ ion and substitutes for two $\mathrm{Na}^{+}$ions leaving a vacancy in place of one of the $\mathrm{Na}^{+}$ions. 
The activity coefficients for $\mathrm{Cs}_{2} \mathrm{CO}_{3}, \mathrm{Cs}_{2} \mathrm{SO}_{4}$, and $\mathrm{CsCl}$ have not yet been determined from volatility measurements, but some enthalpy of solution data exists [9-11] for which the activity coefficients of $\mathrm{Cs}_{2} \mathrm{CO}_{3}$ in $\mathrm{Na}_{2} \mathrm{CO}_{3}(1), \mathrm{Cs}_{2} \mathrm{SO}_{4}$ in $\mathrm{Na}_{2} \mathrm{SO}_{4}(1)$, and $\mathrm{CsCl}$ in $\mathrm{NaCl}(1)$ can be calculated. The enthalpies of mixing for these three binary systems are given in Table 2 . Assuming an ideal entropy of mixing and either a common cation or a common anion, the activity coefficient of component $A$ at infinite dilution of $A$ in a solution of $B$ is given by

$$
R \ln \gamma^{\infty}(A)=1 / 2\left[\Delta H_{\operatorname{mix}} / y(A) y(B)\right]
$$

For $\mathrm{Cs}_{2} \mathrm{CO}_{3}$ in $\mathrm{Na}_{2} \mathrm{CO}_{3}(1), \mathrm{Cs}_{2} \mathrm{SO}_{4}$ in $\mathrm{Na}_{2} \mathrm{SO}_{4}(1)$, and $\mathrm{CsCl}$ in $\mathrm{NaCl}(1)$, the activity coefficients at infinite dilution, $\gamma\left(\mathrm{Cs}_{2} \mathrm{CO}_{3}\right)^{1 / 2}, \gamma\left(\mathrm{Cs}_{2} \mathrm{SO}_{4}\right)^{1 / 2}$, and $\gamma(\mathrm{CsCl})$, at $1200 \mathrm{~K}$ are calculated to be $0.656,0.835$, and 0.701 , respectively. Since each of the activity coefficients are not reduced greatly from unity, each of these solutions does not deviate greatly from ideal solution behavior.

Each of the above solutions have a common anion. Thus, the effect on activity coefficients of mixing of different anions should also be considered. Enthalpy of mixing data for the systems $\mathrm{Na}_{2} \mathrm{CO}_{3}(1)-\mathrm{Na}_{2} \mathrm{SO}_{4}(1)$, $\mathrm{Na}_{2} \mathrm{SO}_{4}(1)-\mathrm{NaCl}(1)$, and $\mathrm{Na}_{2} \mathrm{CO}_{3}(1)-\mathrm{NaCl}(1)$ have been calculated $[12,13]$. These data, derived primarily from optimized phase diagram data, are given in Table 3. The interaction in these systems is also weak. Using eqn (6), the activity coefficients at infinite dilution for $\mathrm{Na}_{2} \mathrm{CO}_{3}$ in $\mathrm{Na}_{2} \mathrm{SO}_{4}$ (1) $\left(\gamma\left(\mathrm{Na}_{2} \mathrm{CO}_{3}\right)^{1 / 2}\right), \mathrm{Na}_{2} \mathrm{SO}_{4}$ in $\mathrm{Na}_{2} \mathrm{CO}_{3}(1)\left(\gamma\left(\mathrm{Na}_{2} \mathrm{SO}_{4}\right)^{1 / 2}\right), \mathrm{Na}_{2} \mathrm{CO}_{3}$ in $\mathrm{NaCl}(1)$ $\left(\gamma\left(\mathrm{Na}_{2} \mathrm{CO}_{3}\right)^{1 / 2}\right), \mathrm{NaCl}$ in $\mathrm{Na}_{2} \mathrm{CO}_{3}(1)(\gamma(\mathrm{NaCl})), \mathrm{Na}_{2} \mathrm{SO}_{4}$ in $\mathrm{NaCl}(1)$ $\left(\gamma\left(\mathrm{Na}_{2} \mathrm{SO}_{4}\right)^{1 / 2}\right)$, and $\mathrm{NaCl}$ in $\mathrm{Na}_{2} \mathrm{SO}_{4}(\mathrm{l})(\gamma(\mathrm{NaCl}))$ are calculated to be 1.000 , $1.000,1.051,1.051,1.157$, and 1.112 , respectively. Each of these activity coefficients are not greatly different from unity, thus each of these solutions does not deviate greatly from ideal solution behavior. For solutions containing cesium rather than sodium, the behavior is expected to be similar.

A last possibility are solutions where neither anions nor cations are common. No data exits which allows activity coefficients to be calculated. However, some indication of the activity coefficient values can be gained by considering the exchange reactions

$$
\begin{aligned}
\mathrm{Cs}_{2} \mathrm{CO}_{3}(\mathrm{l}) & +\mathrm{Na}_{2} \mathrm{SO}_{4}(\mathrm{l})=\mathrm{Cs}_{2} \mathrm{SO}_{4}(\mathrm{l})+\mathrm{Na}_{2} \mathrm{CO}_{3}(\mathrm{l}) \\
\mathrm{K}_{\mathrm{eq}} & =\gamma\left(\mathrm{Na}_{2} \mathrm{CO}_{3}\right) \gamma\left(\mathrm{Cs}_{2} \mathrm{SO}_{4}\right) / \gamma\left(\mathrm{Cs}_{2} \mathrm{CO}_{3}\right) \gamma\left(\mathrm{Na}_{2} \mathrm{SO}_{4}\right)
\end{aligned}
$$


Table 2. Enthalpies of mixing for cesium and sodium binary molten salt systems.

$\Delta \mathrm{H}_{\text {mix }} /\left[\mathrm{x}^{+}\left(\mathrm{Cs}^{+}\right) \mathrm{x}^{+}\left(\mathrm{I} \mathrm{a}^{+}\right)\right]=\mathrm{a}+\mathrm{bx}^{+}\left(\mathrm{Na}^{+}\right), \mathrm{kJ} / \mathrm{mol}$

$\mathrm{x}^{+}\left(\mathrm{Cs}^{+}\right)=$mole fraction of cesium salt

$\mathrm{x}^{+}\left(\mathrm{Na}^{+}\right)=$mole fraction of sodium salt

$\begin{array}{llll}\text { system } & \text { a } & \text { b } & \text { ref. }\end{array}$

$\begin{array}{llrl}\mathrm{Na}_{2} \mathrm{CO}_{3}(1)-\mathrm{Cs}_{2} \mathrm{CO}_{3}(1) & -8.89 & 0.47 & {[7]} \\ \mathrm{Na}_{2} \mathrm{SO}_{4}(1)-\mathrm{Cs}_{2} \mathrm{SO}_{4}(1) & -4.31 & 0.71 & {[8]} \\ \mathrm{NaCl}(1)-\mathrm{CsCl}(1) & -3.22 & -0.33 & {[9]}\end{array}$

Table 3. Enthalpies of mixing for various sodium containing binary molten salt systems.

$\Delta \mathrm{H}_{\operatorname{mix}} /\left[\mathrm{y}^{-}(\mathrm{A}) \mathrm{y}^{-}(\mathrm{B})\right]=\mathrm{a}+\mathrm{b}^{\left.-\mathrm{y}^{-}(\mathrm{B})-\mathrm{y}^{-}(\mathrm{A})\right], \quad \mathrm{kJ} / \text { equivalent }}$

$y^{-}(A)=$ anion equivalent fraction of component $A$

$y^{-}(B)=$ anion equivalent fraction of component $B$

$\begin{array}{llll}\text { system } & \text { a } & \text { b } & \text { ref. }\end{array}$

A - B

$\begin{array}{llll}\mathrm{NaCl}(1)-\mathrm{Na}_{2} \mathrm{CO}_{3}(1) & 0.498 & 0.0 & {[10]} \\ \mathrm{NaCl}(1)-\mathrm{Na}_{2} \mathrm{SO}_{4}(1) & 1.256 & 0.197 & {[10]} \\ \mathrm{Na}_{2} \mathrm{CO}_{3}(1)-\mathrm{Na}_{2} \mathrm{SO}_{4}(1) & 0.0 & 0.0 & {[11]}\end{array}$




$$
\begin{aligned}
& \mathrm{Cs}_{2} \mathrm{CO}_{3}(\mathrm{l})+2 \mathrm{NaCl}(\mathrm{l})=2 \mathrm{CsCl}(\mathrm{l})+\mathrm{Na}_{2} \mathrm{CO}_{3}(\mathrm{l}), \\
& \mathrm{K}_{\mathrm{eq}}=\gamma\left(\mathrm{Na}_{2} \mathrm{CO}_{3}\right) \gamma(\mathrm{CsCl})^{2} / \gamma\left(\mathrm{Cs}_{2} \mathrm{CO}_{3}\right)(\mathrm{NaCl})^{2}
\end{aligned}
$$

and

$$
\begin{array}{r}
\mathrm{Cs}_{2} \mathrm{SO}_{4}(\mathrm{l})+2 \mathrm{NaCl}(\mathrm{l})=2 \mathrm{CsCl}(1)+\mathrm{Na}_{2} \mathrm{SO}_{4}(\mathrm{l}) \\
\mathrm{K}_{\text {eq }}=\gamma\left(\mathrm{Na}_{2} \mathrm{SO}_{4}\right) \gamma(\mathrm{CsCl})^{2} / \chi\left(\mathrm{Cs} 2 \mathrm{SO}_{4}\right) \gamma(\mathrm{NaCl})^{2}
\end{array}
$$

The equilibrium constants are given in terms of activity coefficients only because the equivalent fractions of the anions and cations drop out of the equations. Taking the thermodynamic functions for $\mathrm{CsCl}(1), \mathrm{NaCl}(1)$, $\mathrm{Na}_{2} \mathrm{CO}_{3}(1)$, and $\mathrm{Na}_{2} \mathrm{SO}_{4}(1)$ from the JANAF tables [5], the thermodynamic functions for $\mathrm{Cs}_{2} \mathrm{SO}_{4}(1)$ from Barin [6], and the thermodynamic functions for $\mathrm{Cs}_{2} \mathrm{CO}_{3}$ (1) given herein (Table 1), the equilibrium constant for each of the above reactions can be calculated. At $1200 \mathrm{~K}$, the equilibrium constants are calculated to be $6.16,93.8$, and 15.2 , respectively. Thus, the products in reactions (7) to (9) are more stable than the reactants and the activity coefficients of the products are greater than the activity coefficients of the reactants.

Experimental

\section{Transpiration Method:}

In the transpiration method [14], a known amount of carrier gas is slowly passed over a solid or bubbled into a liquid in a furnace chamber, such that any volatile gases produced become entrained in the carrier gas and are swept out of the chamber where the volatilized material then condenses on a substrate and is analyzed. The carrier gas may also contain reactive gases that are important in controlling the formation of the vapor species. For these experiments, $\mathrm{CO}_{2}(\mathrm{~g})$ and $\mathrm{H}_{2} \mathrm{O}(\mathrm{g})$ are the reactive gases. Variation of flow rate of the carrier gas permits one to establish the range of flow rates under which the carrier gas becomes saturated with the equilibrium vapor pressure of the volatilizing material. If the flow rate is too slow, then diffusional transport of the saturated vapor dominates over entrainment by the carrier gas. A vapor pressure which is apparently higher than the saturated equilibrium vapor pressure will result. If the flow rate is too high, the residence time of the carrier gas is not long enough to obtain saturation of the volatile material. A vapor pressure which is apparently lower than the saturated equilibrium vapor pressure will result. At intermediate flow rates, the residence time of the carrier 
gas is long enough such that the carrier gas is saturated with the volatile material, but short enough such that transport by gaseous diffusion is insignificant. This is the region in which the apparent vapor pressure equals the saturated equilibrium vapor pressure and is called the "plateau" region because a plot of apparent vapor pressure as a function of flow rate will be flat over this region with a rise in the curve at low flow rates and a drop in the curve at high flow rates.

The transpiration method also allows one to obtain the formula for the volatilizing species by varying the pressures of the reactive gases. In the case of cesium, the major vapor species above the carbonate based salt are expected to be either $\mathrm{CsOH}(\mathrm{g})$ or $\mathrm{CsCl}(\mathrm{g})$ which are given, respectively, by the reactions and the equilibrium constants

$$
\begin{aligned}
& 1 / 2 \mathrm{Cs}_{2} \mathrm{CO}_{3}(\mathrm{l})+1 / 2 \mathrm{H}_{2} \mathrm{O}(\mathrm{g})=\mathrm{CsOH}(\mathrm{g})+1 / 2 \mathrm{CO}_{2}(\mathrm{~g}) \\
& \mathrm{Keq}=\mathrm{p}(\mathrm{CsOH}) \mathrm{p}\left(\mathrm{CO}_{2}\right)^{1 / 2 / p}\left(\mathrm{H}_{2} \mathrm{O}\right)^{1 / 2} \mathrm{a}\left(\mathrm{Cs}_{2} \mathrm{CO}_{3}\right)^{1 / 2}
\end{aligned}
$$

and

$$
\begin{aligned}
\mathrm{CsCl}(1) & =\mathrm{CsCl}(\mathrm{g}) \\
\mathrm{K}_{\mathrm{eq}} & =\mathrm{p}(\mathrm{CsCl}) / \mathrm{a}(\mathrm{CsCl}) .
\end{aligned}
$$

From the equilibrium constant expression for reaction (10), the $\mathrm{CsOH}(\mathrm{g})$ pressure is inversely dependent upon the square root of the $\mathrm{CO}_{2}(\mathrm{~g})$ pressure and directly dependent upon the square root of the $\mathrm{H}_{2} \mathrm{O}(\mathrm{g})$ pressure. Other pressure dependencies would indicate other species. For reaction (11), the $\mathrm{CsCl}(\mathrm{g})$ pressure will be independent of the $\mathrm{CO}_{2}(\mathrm{~g})$ and $\mathrm{H}_{2} \mathrm{O}(\mathrm{g})$ pressures.

\section{Description of Transpiration Equipment:}

In order to conduct the cesium volatility experiments, two transpiration apparatuses were used, a horizontal arrangement and a vertical arrangement. The horizontal apparatus is a modified version of that used previously for the uranium oxide volatility measurements [15]. This unit was used for the cesium in ash experiments, for some experiments on pure cesium carbonate, and for some experiments on a cesium carbonate and sodium carbonate mixture. The horizontal unit is illustrated schematically in Figure 3 . The furnace is a Marshall furnace with $\mathrm{Pt} / \mathrm{Rh}$ windings, rated to $1450^{\circ} \mathrm{C}$ in air, and has a uniform temperature hot zone about $17 \mathrm{~cm}$ long. The furnace tube was alumina, $4.5 \mathrm{~cm} O D$ by $60 \mathrm{~cm}$ long. Stainless steel end caps designed with Vitcn 


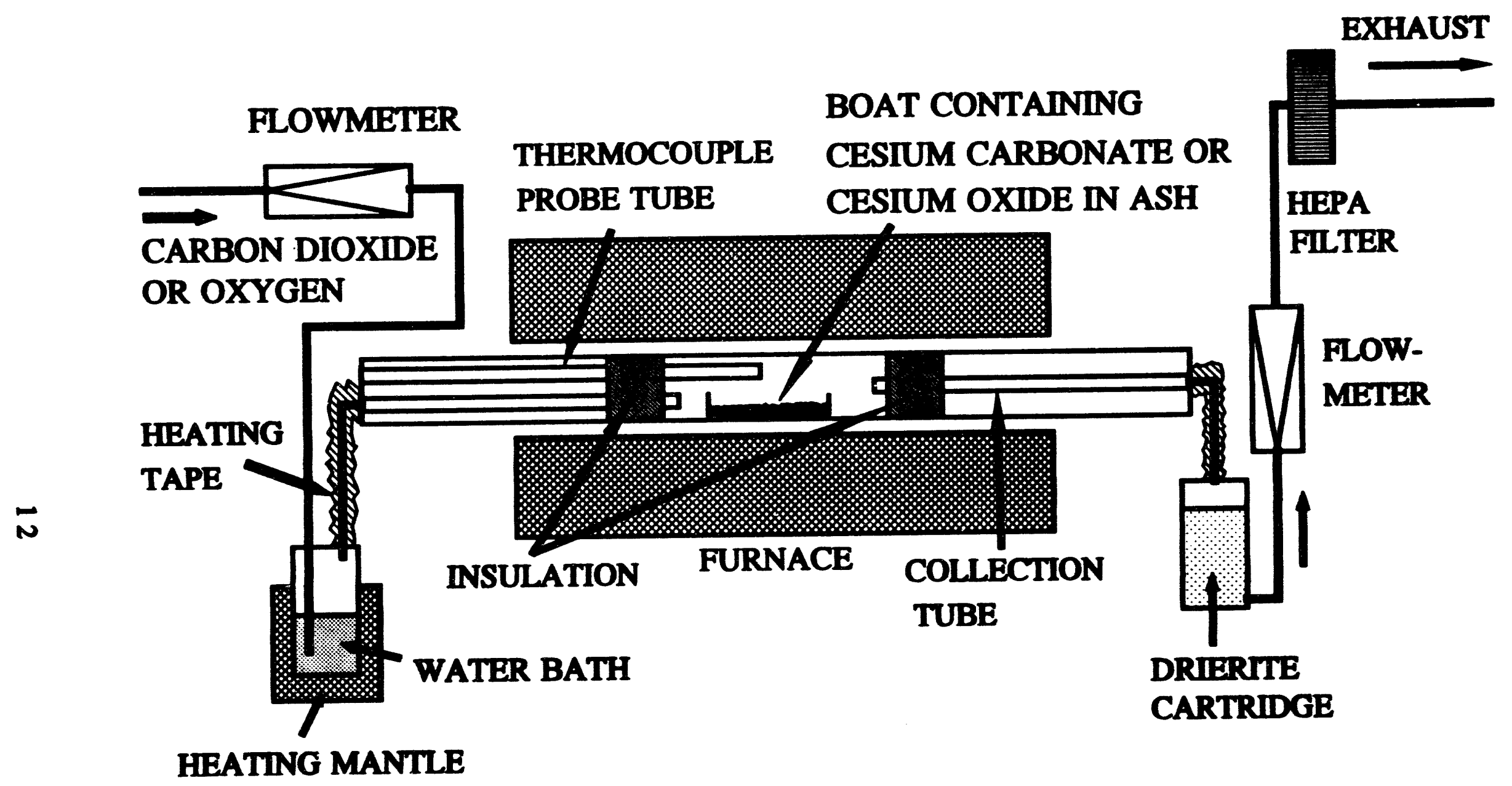

Figure 3. Schematic diagram of the horizontal transpiration apparatus. 
o-ring seal compression fittings were used to seal off the ends of the furnace tube. From the upstream side, a gas inlet tube extended through a Viton o-ring seal compression fitting on a stainless steel end cap, through two alumina disks, $4.5 \mathrm{~cm}$ diameter by $3 \mathrm{~mm}$ thick, holding between them about $6 \mathrm{~cm}$ of Kaowool insulation (53wt\% $\mathrm{SiO}_{2}$ and $47 \mathrm{wt} \% \mathrm{Al}_{2} \mathrm{O}_{3}$ ) and to the border of the hot zone. The alumina disks and insulation were used to better define the hot zone. The thermocouple protection tube ran parallel to the gas inlet tube and also extended through a Viton o-ring seal compression fitting in the end cap, through the two alumina disks and insulation, and to the center of the hot zone. From the down stream side, a fused silica exit tube, $6 \mathrm{~mm} O D$, extended through a Viton o-ring seal compression fitting on the other stainless steel end cap, through two additional alumina disks, $4.5 \mathrm{~cm}$ diameter by $3 \mathrm{~mm}$ thick, holding another $6 \mathrm{~cm}$ of Kaowool insulation, and to the border of the hot zone. The gas exit tube served as a collector tube for deposition of volatilized cesium and is referred to hereafter as the collection tube. Platinum boats, $2.5 \mathrm{~cm}$ wide by $6 \mathrm{~cm}$ long by $1 \mathrm{~cm}$ high, were used to contain the ash and the carbonate samples. For most of the runs using carbonate samples, the inside of the furnace tube in the hot zone and the alumina disks at the edge of the hot zone were lined with platinum foil, $0.08 \mathrm{~mm}$ thick, to minimize any reaction of the cesium vapor with the alumina walls. Temperatures were meisured by a type-S thermocouple which was assumed to be accurate to within $\pm 2^{\circ} \mathrm{C}$ based on previous checks made with two other type-S thermocouples [15].

The vertical apparatus is similar in many ways to the horizontal apparatus. The vertical unit is illustrated schematically in Figure 4 . This unit was used for the bulk of the experiments on carbonate based melts. Again, the furnace is a Marshall furnace with $\mathrm{Pt} / \mathrm{Rh}$ windings, rated to $1450^{\circ} \mathrm{C}$ in air, and has a uniform temperature hot zone of about $12 \mathrm{~cm}$ in the vertical position. The furnace tube was alumina, $7 \mathrm{~cm}$ OD by $47 \mathrm{~cm}$ long, and closed on the bottom end. A stainless steel end cap designed with a Viton o-ring compression seal fitting was used to seal off the top end of the furnace tube. Two alumina tubes, a $9 \mathrm{~mm}$ OD gas inlet tube and a $9 \mathrm{~mm}$ OD thermocouple protection tube, and one, $9 \mathrm{~mm} O D$, fused silica tube for sample collection and gas outlet, were extended through Viton oring compression seal fittings on the stainless steel endcap, through two alumina disks, $6 \mathrm{~cm}$ diameter by $4 \mathrm{~mm}$ thick, holding between them about $10 \mathrm{~cm}$ of Kaowool insulation. The gas inlet tube and the thermocouple protection tube were extended down into the carbonate melt about $1 \mathrm{~cm}$ 


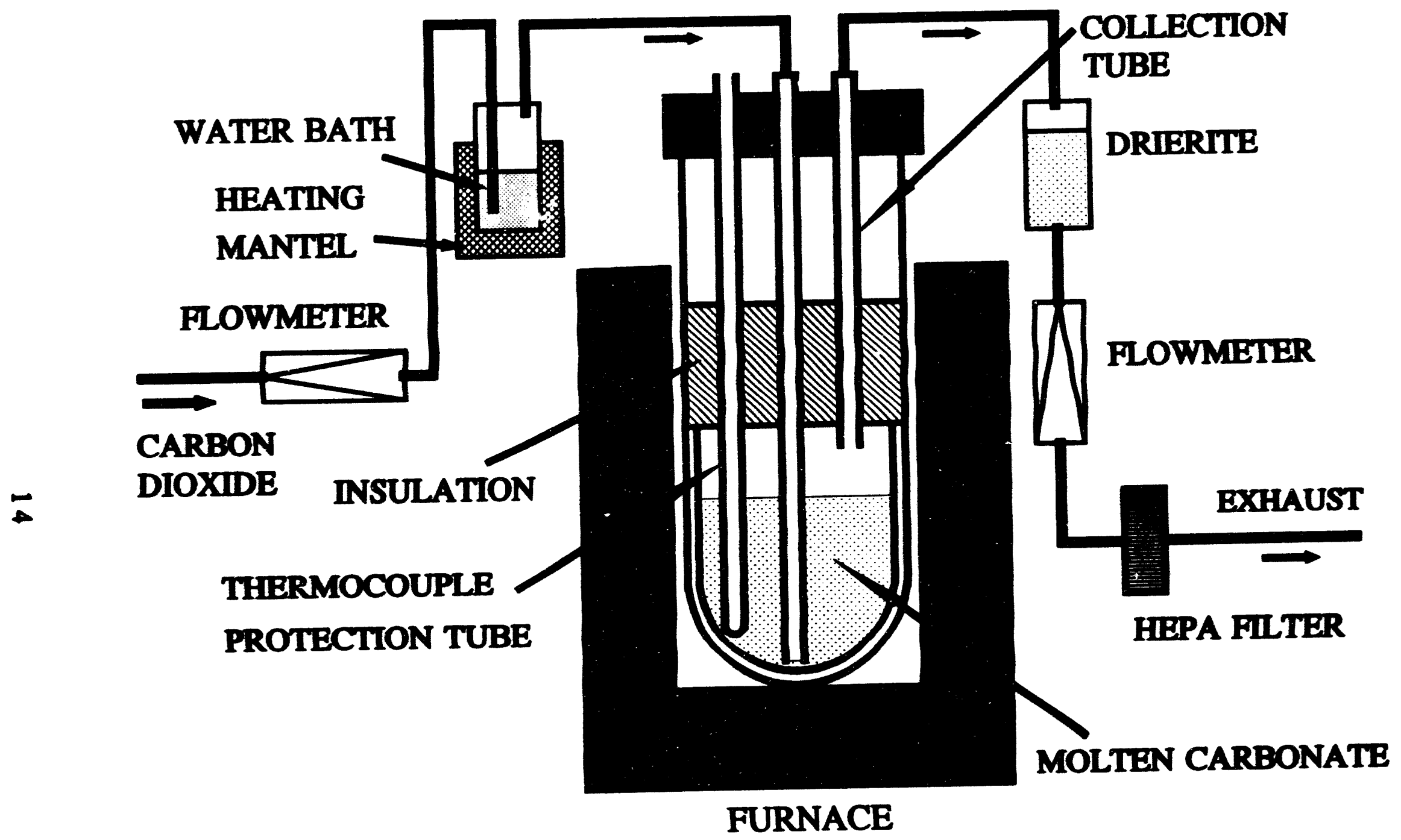

Figure 4. Schematic diagram of the vertical transpiration apparatus. 
from the bottom. The collection tube was extended only to the end of the hot zone in the gas space above the melt. A round bottom alumina crucible, $5.9 \mathrm{~cm}$ OD by $15.3 \mathrm{~cm}$ high, was used to contain the carbonate melt. Temperatures were measured either by a type-S or a type-K thermocouple. In each experiment a back-up type-K thermocouple was also used which never differed by more than $3^{\circ} \mathrm{C}$ from the primary thermocouple.

In both the horizontal apparatus and the vertical apparatus, a water saturator was located upstream of the furnace. The water saturator was made of a 6-mm-thick wall aluminum vessel with an $800 \mathrm{~cm}^{3}$ capacity and provided with a fritted stainless steel disperser for the carrier gas which was located $1 \mathrm{~cm}$ above the bottom of the vessel. The water level in the saturator was typically $500-600 \mathrm{~cm}^{3}$ during the runs and the vessel was heated by a Glas-col mantle. A desiccant cartridge filled with Drierite (CaSO4) was located downstream of the furnace. This cartridge was removed and weighed before and after an experiment to determine the total amount of water transported. All gas lines were stainless steel. Valves were also stainless steel with Viton rubber seals. Stainless steel compression fittings with Viton o-ring seals were used to connect the inlet and collection tubes to the gas lines. Briskheat silicone rubber heating tapes were wrapped around the lines leading from the water saturator to the furnace and from the furnace to the desiccant and maintained at around $150^{\circ} \mathrm{C}$ in order to prevent water vapor from condensing in the lines. Precision Flow devices PFD-401 mass flow controllers were used to control $\mathrm{O}_{2}(\mathrm{~g})$ and $\mathrm{CO}_{2}(\mathrm{~g})$ flow inputs and to monitor the gas flow output. The input flow controllers were calibrated by the supplier for $\mathrm{O}_{2}(\mathrm{~g})$. The readings were measured in $\mathrm{cm}^{3} / \mathrm{min}$ of $\mathrm{O}_{2}(\mathrm{~g})$ at stp. The capacity of the flow controller was $50 \mathrm{~cm} 3 / \mathrm{min}$ for the ash experiments and $100 \mathrm{~cm} 3 / \mathrm{min}$ for all other experiments. The accuracy of the mass flow controller is $\pm 1 \%$ of the full scale reading and the reproducibility is $\pm 0.1 \%$ of the full scale reading. Conversion to $\mathrm{CO}_{2}(\mathrm{~g})$ flow rates of the $\mathrm{O}_{2}(\mathrm{~g})$ controllers was made by multiplying the measured flow by the heat capacity of $\mathrm{O}_{2}(\mathrm{~g})$ at $298 \mathrm{~K}$ divided by the heat capacity of $\mathrm{CO}_{2}(\mathrm{~g})$ at $298 \mathrm{~K}$ both taken from the JANAF tables [5]. The accuracy of this conversion is $\pm 2 \%$ of the full scale reading. Weighings were carried out on an Ohaus GT 2100 electronic balance with a capacity of $2100 \mathrm{~g}$ and an accuracy of $\pm 0.01 \mathrm{~g}$ or on a Mettler Instruments semi-micro analytical balance with a capacity of $200 \mathrm{~g}$ and an accuracy of $\pm 0.00002 \mathrm{~g}$. 


\section{Collection Tube Analysis}

Before analysis, the outside of the silica collection tubes were wiped with a wet cloth to remove any cesium carbonate on the exterior. Each tube was then broken into three pleces, placed into a polystyrene plastic test tube, and submerged in a solution which was $10 \%$ concentrated $\mathrm{HNO}_{3}$ and $4 \%$ concentrated HF. The plastic test tube with the dissolving sample was then placed in sonic bath for about 2 hours. After which, it was allowed to sit in the concentrated acid solution for at least 2 days. The solution was then decanted into a $100 \mathrm{ml}$ Teflon volumetric flask. The plastic test tube with the remnants of the collection tubes was filled with water and allowed to sit for at least a day. The solution was then added to the original and the volumetric flask was filled to $100 \mathrm{ml}$. The sample was then analyzed for cesium by the Inductively Coupled Plasma-Mass Spectrometry (ICP-MS) technique which is sensitive enough to detect as little as 1 nanogram of cesium and the results have an accuracy of $\pm 5 \%$.

\section{Starting Materials}

$\mathrm{Na}_{2} \mathrm{CO}_{3}$ powder of $99.97 \%$ purity was obtained from Baker Analyzed. $\mathrm{Na}_{2} \mathrm{SO}_{4}$ powder of $99.96 \%$ purity was obtained from EM Scientific. $\mathrm{NaCl}$ powder of $99.97 \%$ purity was obtained from EM Scientific. $\mathrm{Cs}_{2} \mathrm{CO}_{3}$ powder of 99.9\% purity was obtained from Alfa Products. (Used only in experiments $\# 10$ to $\# 20$.) $\mathrm{Cs}_{2} \mathrm{CO}_{3}$ powder of $99.996 \%$ purity was obtained from Johnson Mathey Specialty Products. CsNO3 powder of 99\% purity was obtained from Aldrich. Spectral grade SiO2 powder -325 mesh was obtained from the Pennsylvania Glass Sand Corporation. Pellets, roughly $1 / 8$ " in size, of molecular sieve $5 \mathrm{~A}$ were obtained from Linde. Coal flyashes, designated as SRM 1633a and SRM 2690, were obtained from the National Institute of Standards and Technology (NIST) as standard reference materials. Compositions provided by NIST for the ashes are listed in Table 4.

\section{Preparation and Characterization of Sample Materials}

For the cesium in ash experiments, 0.402498 of $\mathrm{C}_{8} \mathrm{NO}_{3}$ were hand blended using a spatula with $10.57 \mathrm{~g}$ of SRM $2690 \mathrm{ash}$. The mixture was ground in a mortar and pestle to pass through a 200 mesh sieve and then fired at $1150^{\circ} \mathrm{C}$ for 19 hours in an alumina crucible. The product sintered hard. Weight losses were $0.09 \mathrm{~g}$ for grinding and sieving and $0.24 \mathrm{~g}$ for heat treatment of which $0.13 \mathrm{~g}$ can be attributed to nitrate decomposition. The sintered material was then crushed and ground again to pass through 
Table 4. Composition of NIST standard reference material coal nyashes given in weight percent of constituent oxides.

\begin{tabular}{lcc} 
oxide & SRM 1633a & SRM 2690 \\
\hline $\mathrm{Na2O}$ & $0.23 \pm 0.01$ & $0.32 \pm 0.03$ \\
$\mathrm{~K}_{2} \mathrm{O}$ & $2.26 \pm 0.07$ & $1.25 \pm 0.05$ \\
$\mathrm{MgO}$ & $0.75 \pm 0.02$ & $2.54 \pm 0.08$ \\
$\mathrm{CaO}$ & $1.55 \pm 0.01$ & $7.99 \pm 0.18$ \\
$\mathrm{SrO}$ & $0.10 \pm 0.01$ & 0.24 \\
$\mathrm{BaO}$ & 0.17 & 0.73 \\
$\mathrm{MnO}$ & $0.02 \pm 0.01$ & 0.04 \\
$\mathrm{Al}_{2} \mathrm{O}_{3}$ & $27.02 \pm 1.89$ & $23.33 \pm 0.53$ \\
$\mathrm{Fe}_{2} \mathrm{O}_{3}$ & $13.44 \pm 0.14$ & $5.10 \pm 0.09$ \\
$\mathrm{SiO}_{2}$ & $48.78 \pm 1.71$ & $55.30 \pm 0.36$ \\
$\mathrm{TiO}_{2}$ & 1.33 & $0.87 \pm 0.02$ \\
$\mathrm{SO}_{3}$ & 0.45 & $0.37 \pm 0.02$ \\
$\mathrm{P}_{2} \mathrm{O}_{5}$ & $\cdots$ & $1.19 \pm 0.02$
\end{tabular}

Table 5. Weight percent composition of cesium in samples before and after experiments.

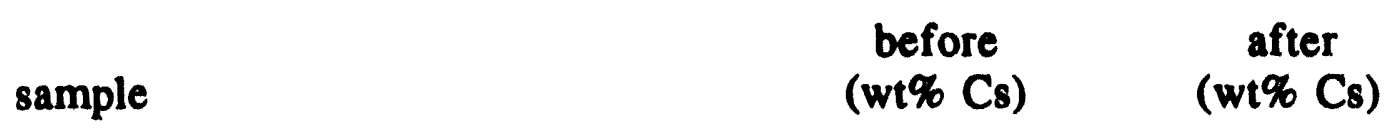

in 2690 ash

$0.42 w t \% C s 2 O$
$0.40^{\mathrm{a}}$
$0.17^{a}$

in $\mathrm{Na}_{2} \mathrm{CO}_{3}$

$13.9 \mathrm{wt} \% \mathrm{Cs}_{2} \mathrm{CO}_{3}$

$11.4^{b}$

$8.6 \mathrm{a}$

$10.2 \mathrm{wt} \% \mathrm{Cs}_{2} \mathrm{CO} 3 / 22.5 \mathrm{wt} \% \mathrm{Na} 2 \mathrm{SO} 4$

$8.3^{b}$

$6.7^{\mathrm{a}}$

$12.5 w t \% \mathrm{Cs}_{2} \mathrm{CO} 3 / 10.0 w t \% \mathrm{NaCl}$

$8.2^{b}$

$10.0^{\mathrm{a}}$

$0.2 \mathrm{wt}_{\mathrm{t}} \mathrm{Cs}_{2} \mathrm{CO}_{3}$

$0.16^{b}$

$0.092^{\mathrm{a}}$

$0.2 w_{t} \% \mathrm{Cs}_{2} \mathrm{CO}_{3} / 2.0 \mathrm{wt} \% 1633 \mathrm{a}$ ash

$0.16^{b}$

$0.090^{\mathrm{a}}$

abased on ICP-MS chemical analysis

b based on weights of chemicals added 
a 200 mesh sieve. Analysis of this material by the ICP-MS method showed that the ash contained $0.40 \mathrm{wt} \%$ cesium. In the transpiration experiments, $4.9 \mathrm{~g}$ of this material, designated as $0.42 \mathrm{wt} \% \mathrm{Cs}_{2} \mathrm{O} / 2690$, was placed in a platinum boat. After the transpirations experiments were completed, analysis showed that the material was $0.17 \mathrm{wt} \%$ cesium.

For the horizontal apparatus transpiration experiments on carbonate based salts, between 4 and $12 \mathrm{~g}$ of $\mathrm{Cs}_{2} \mathrm{CO}_{3}$ was used for the runs on pure $\mathrm{Cs}_{2} \mathrm{CO}_{3}$, and $9.859 \mathrm{~g}$ of $\mathrm{Na}_{2} \mathrm{CO}_{3}$ and $1.597 \mathrm{~g}$ of $\mathrm{Cs}_{2} \mathrm{CO}_{3}$ was blended and used for the runs on $13.9 \mathrm{wt} \% \mathrm{C}_{2} \mathrm{CO}_{3} / \mathrm{Na}_{2} \mathrm{CO}_{3}$.

For the vertical apparatus transpiration experiments, the carbonate based samples were made by taking a spatula and hand blending the appropriate amounts of the desired materials in a round bottom alumina crucible, $5.9 \mathrm{~cm}$ OD by $15.3 \mathrm{~cm}$ high, which was then placed in the transpiration apparatus. For the runs on $13.9 \mathrm{wt} \% \mathrm{Cs}_{2} \mathrm{CO}_{3} / \mathrm{Na}_{2} \mathrm{CO}_{3}, 120.00 \mathrm{~g}$ of $\mathrm{Na}_{2} \mathrm{CO}_{3}$ was blended with $19.42 \mathrm{~g}$ of $\mathrm{Cs}_{2} \mathrm{CO}_{3}$. For the runs on $10.2 \mathrm{wt} \% \mathrm{Cs}_{2} \mathrm{CO}_{3} / 22.5 \mathrm{wt} \% \mathrm{Na}_{2} \mathrm{SO}_{4} / \mathrm{Na}_{2} \mathrm{CO}_{3}, 200.00 \mathrm{~g}$ of $\mathrm{Na}_{2} \mathrm{CO}_{3}$ was blended with $67.02 \mathrm{~g}$ of $\mathrm{Na}_{2} \mathrm{SO}_{4}$ and $30.30 \mathrm{~g}$ of $\mathrm{Cs}_{2} \mathrm{CO}_{3}$. For the runs on $12.5 \mathrm{wt} \% \mathrm{Cs}_{2} \mathrm{CO}_{3} / 10.0 \mathrm{wt} \% \mathrm{NaCl} / \mathrm{Na}_{2} \mathrm{CO}_{3}, 232.42 \mathrm{~g}$ was blended with $37.62 \mathrm{~g}$ of $\mathrm{Cs}_{2} \mathrm{CO}_{3}$ and $29.98 \mathrm{~g}$ of NaCl . For the runs on $1 \mathrm{wt} \% \mathrm{Cs}_{2} \mathrm{CO}_{3} / 10 \mathrm{wt} \% 1633 \mathrm{a} /$ $\mathrm{Na}_{2} \mathrm{CO}_{3}, 220.00 \mathrm{~g}$ of $\mathrm{Na}_{2} \mathrm{CO}_{3}$ was blended with $2.001 \mathrm{~g}$ of $\mathrm{Cs}_{2} \mathrm{CO}_{3}$ and $22.01 \mathrm{~g}$ of SRM 1633a ash. For the remaining samples, about $10 \%$ of the $\mathrm{Na}_{2} \mathrm{CO}_{3}$ was retained and added to the top of the mixture after it was blended. For the experiments on $0.2 \mathrm{wt} \% \mathrm{Cs}_{2} \mathrm{CO}_{3} / 2.0 \mathrm{wt} \% 1633 \mathrm{a} / \mathrm{Na}_{2} \mathrm{CO}_{3}$, $244.50 \mathrm{~g}$ of $\mathrm{Na}_{2} \mathrm{CO}_{3}$ was blended with $5.01 \mathrm{~g}$ of $1633 \mathrm{a}$ ash and $0.5008 \mathrm{~g}$ of $\mathrm{Cs}_{2} \mathrm{CO}_{3}$. For the experiments on $0.2 \mathrm{wt}_{\mathrm{O}} \mathrm{Cs}_{2} \mathrm{CO}_{3} / \mathrm{Na}_{2} \mathrm{CO}_{3}, 249.51 \mathrm{~g}$ of $\mathrm{Na}_{2} \mathrm{CO}_{3}$ was blended with 0.5002 \& $\mathrm{Cs}_{2} \mathrm{CO}_{3}$. For the experiments on $0.2 \mathrm{wt} \% \mathrm{Cs}_{2} \mathrm{CO}_{3} / 2.0 \mathrm{wt} \%$ sieve $5 \mathrm{~A} / \mathrm{Na}_{2} \mathrm{CO}_{3}, 244.5 \mathrm{~g}_{\mathrm{g}}$ of $\mathrm{Na}_{2} \mathrm{CO}_{3}$ was blended with $5.00 \mathrm{~g}$ of Linde molecular sieve $5 \mathrm{~A}$ and $0.5023 \mathrm{~g}$ of $\mathrm{Cs}_{2} \mathrm{CO}_{3}$. For the experiments on $0.2 \mathrm{wt} \% \mathrm{Cs}_{2} \mathrm{CO}_{3} / 2.0 \mathrm{wt} \% \mathrm{SiO}_{2} / \mathrm{Na}_{2} \mathrm{CO}_{3}, 244.50 \mathrm{~g}$ of $\mathrm{Na}_{2} \mathrm{CO}_{3}$ was blended with $5.00 \mathrm{~g}$ of $\mathrm{SiO}_{2}$ and $0.5043 \mathrm{~g}$ of $\mathrm{Cs}_{2} \mathrm{CO}_{3}$, and for the experiments on pure $\mathrm{Cs}_{2} \mathrm{CO}_{3}, 199.72 \mathrm{~g}$ of $\mathrm{Cs}_{2} \mathrm{CO}_{3}$ was used.

Weight percent compositions of cesium in some samples before and after transpiration experiments are given in Table 5 . With the exception of the $0.42 \mathrm{wt} \% \mathrm{Cs}_{2} \mathrm{O} / 2690$ ash material, the cesium compositions before the experiments were calculated from the weights of the starting materials used. After the transpiration experiments, the cesium compositions were obtained by ICP-MS analysis. With the exception of the 
$10.2 \mathrm{wt} \% \mathrm{Cs}_{2} \mathrm{CO}_{3} / 22.5 \mathrm{wt} \% \mathrm{Na}_{2} \mathrm{SO}_{4} / \mathrm{Na}_{2} \mathrm{CO}_{3}$ sample, a decrease in cesium composition after the transpiration experiments was observed.

\section{Analysis of Results}

The experiments conducted on the $0.42 \mathrm{wt} \% \mathrm{Cs}_{82} 0 / 2690$ ash material using the horizontal apparatus are summarized in Tables 6 and 7 . With finely divided solid present, the horizontal apparatus is expected to provide good equilibrium measurements. The experiments conducted on the molten carbonate based systems are summarized in Tables 8 and 9. Both the horizontal and vertical apparatuses were used for these experiments. The vertical apparatus is expected to more readily achieve equilibrium results since the carrier gas is bubbled through the melt which results in a high contact area. However, the horizontal apparatus was available from previous work on uranium oxide volatility [14], and experiments were conducted on the apparatus to obtain additional information.

\section{Water Vapor Effect}

The effect of leaving out water vapor was tested a number of times. With the exception of the experiments on $12.5 \mathrm{wt} \% \mathrm{Cs}_{2} \mathrm{CO}_{3} /$ $10.0 \mathrm{wt} \% \mathrm{NaCl} / \mathrm{Na}_{2} \mathrm{CO}_{3}$, the data show that the cesium volatility is reduced at least an order of magnitude when $\mathrm{H}_{2} \mathrm{O}(\mathrm{g})$ is absent. This verifies that $\mathrm{CsOH}(\mathrm{g})$ is the major vapor species when $\mathrm{H}_{2} \mathrm{O}(\mathrm{g})$ is present, as expected. When $10.0 \mathrm{wt} \% \mathrm{NaCl}$ was present in the sample, $\mathrm{CsCl}(\mathrm{g})$ became the dominant species and as expected $\mathrm{H}_{2} \mathrm{O}(\mathrm{g})$ has no effect on the vapor pressure of $\mathrm{CsCl}(\mathrm{g})$.

\section{Horizontal versus Vertical Configuration}

Two molten carbonate compositions were studied on both apparatuses, pure $\mathrm{Cs}_{2} \mathrm{CO}_{3}$ and $13.9 \mathrm{wt} \% \mathrm{Cs}_{2} \mathrm{CO}_{3} / \mathrm{Na}_{2} \mathrm{CO}_{3}$. For pure $\mathrm{Cs}_{2} \mathrm{CO}_{3}$, the volatility measurements from both apparatuses are compared in Figure 5. The consistency of the data from the vertical apparatus is excellent whereas the consistency of the data from the horizontal apparatus is poor. With the exception of the data at $1173 \mathrm{~K}$ and one data point at $1223 \mathrm{~K}$, the vapor pressure data from the horizontal furnace lies between a factor of 3 and 40 lower than in the vertical apparatus. For $13.9 \mathrm{wt} \% \mathrm{Cs}_{2} \mathrm{CO}_{3} / \mathrm{Na}_{2} \mathrm{CO}_{3}$, the volatility measurements from both apparatuses are compared in Figure 6. Both sets of data show good consistency. With one exception, the vapor pressure data from the horizontal furnace is about a factor of 3 lower than 
Table 6. Summary of transpiration experiments for experiments on Cs $20(8)$ interacted with ash.

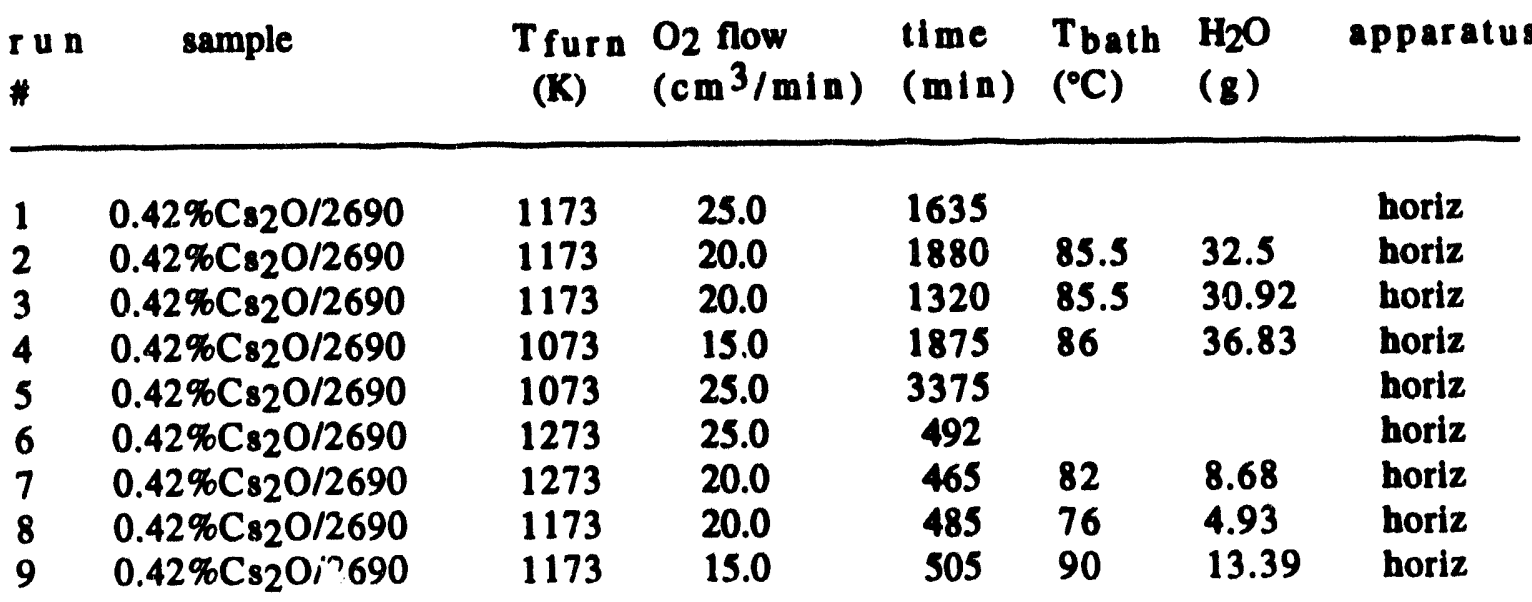

Table 7. Summary of transpiration experiments for experiments on Cs2O(s) interacted with ash.

\begin{tabular}{|c|c|c|c|c|c|c|c|}
\hline \multirow{2}{*}{$\begin{array}{l}\mathbf{r} \mathbf{~ n} \\
\#\end{array}$} & \multicolumn{2}{|c|}{ moles of gas } & \multirow[b]{2}{*}{ total } & \multirow{2}{*}{$\begin{array}{l}p\left(\mathrm{O}_{2}\right) \\
(\mathbf{a t m})\end{array}$} & \multirow{2}{*}{$\begin{array}{l}\mathbf{p}\left(\mathrm{H}_{2} \mathrm{O}\right) \\
(\text { atm })\end{array}$} & \multirow{2}{*}{$\begin{array}{r}C s \\
(n g)\end{array}$} & \multirow{2}{*}{$\begin{array}{l}\mathbf{p}(\text { Cs total }) \\
\quad \text { (atm) }\end{array}$} \\
\hline & $\mathrm{O}_{2}$ & $\mathrm{H}_{2} \mathrm{O}$ & & & & & \\
\hline 1 & 1.8236 & & 1.8236 & 1.000 & & 7375 & $3.043 \times 10^{-8}$ \\
\hline 2 & 1.6775 & 1.8029 & 3.4804 & 0.4820 & 0.5180 & 630 & $1.362 \times 10^{-9}$ \\
\hline 3 & 1.1778 & 1.7163 & 2.8941 & 0.4070 & 0.5930 & 303 & $7.877 \times 10^{-10}$ \\
\hline 4 & 1.2548 & 2.0444 & 3.2992 & 0.3803 & 0.6197 & 89 & $2.030 \times 10^{-10}$ \\
\hline 5 & 3.7644 & & 3.7644 & 1.000 & & 121 & $2.418 \times 10^{-10}$ \\
\hline 6 & 0.5488 & & 0.5488 & 1.000 & & 885 & $1.213 \times 10^{-8}$ \\
\hline 7 & 0.4149 & 0.4818 & 0.8967 & 0.4627 & 0.5373 & 1073 & $9.004 \times 10^{-9}$ \\
\hline 8 & 0.4328 & 0.2737 & 0.7065 & 0.6126 & 0.3874 & 89 & $9.478 \times 10^{-10}$ \\
\hline 9 & 0.3380 & 0.7433 & 1.0813 & 0.3126 & 0.6874 & 98 & $6.819 \times 10^{-10}$ \\
\hline
\end{tabular}


Table 8. Summary of transpiration experiments for experiments on molten carbonates.

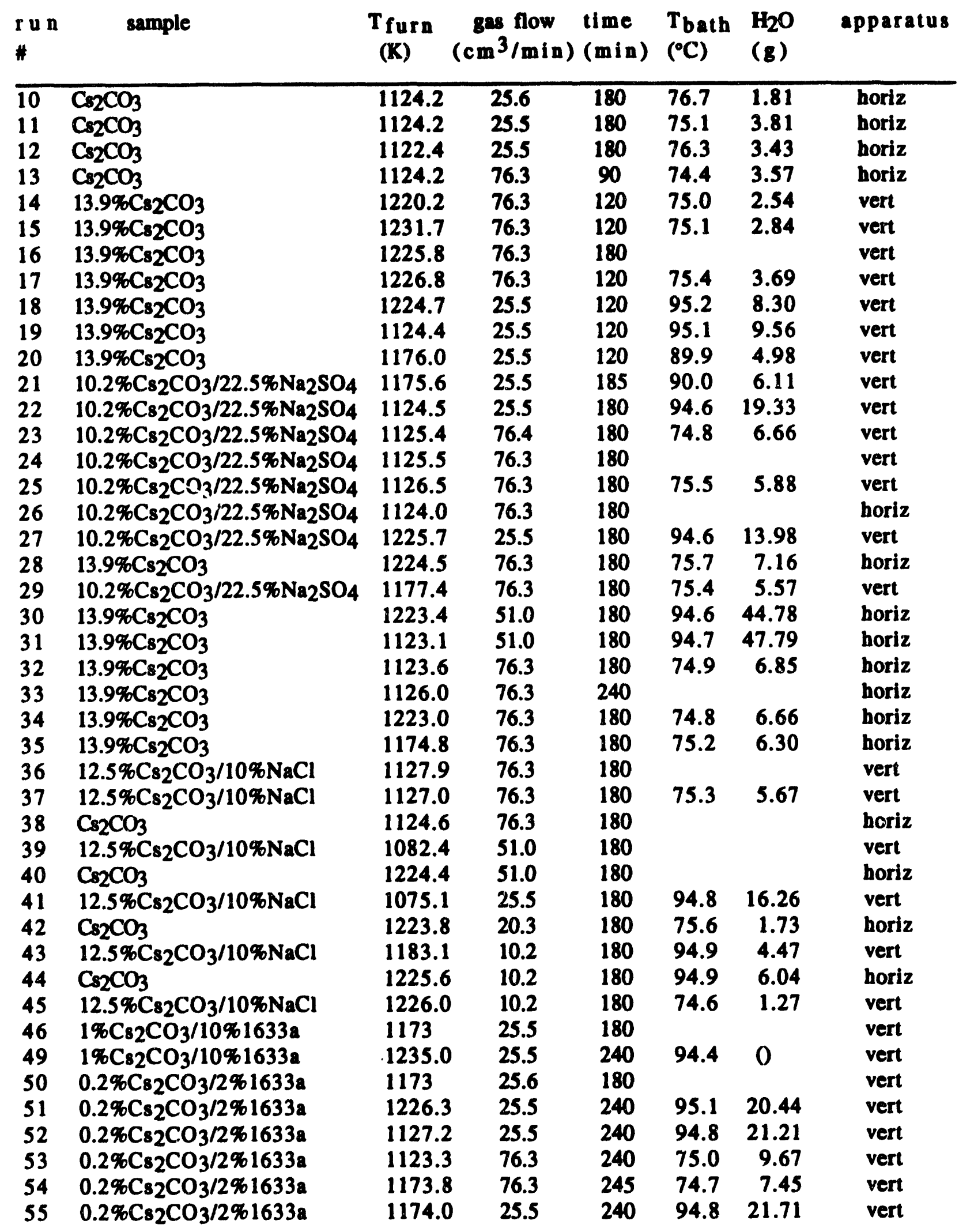


Table 8. (cont.) Summary of transpiration experiments for experiments on molten carbonates.

\begin{tabular}{|c|c|c|c|c|c|c|c|}
\hline $\begin{array}{l}\text { r u n } \\
\text { \# }\end{array}$ & sample & $\underset{\text { (K) }}{\text { Tefurn }}$ & $\begin{array}{c}\text { gas flow } \\
\left(\mathrm{cm}^{3} / \mathrm{min}\right)\end{array}$ & $\begin{array}{l}\text { time } \\
(m i n)\end{array}$ & $\begin{array}{l}T_{\text {bath }} \\
\left({ }^{\circ} \mathrm{C}\right)\end{array}$ & $\begin{array}{l}\mathrm{H}_{2} \mathrm{O} \\
(\mathrm{g})\end{array}$ & apparat \\
\hline $\begin{array}{l}56 \\
57\end{array}$ & $0.2 \% \mathrm{C}_{2} \mathrm{CO}_{3} / 2 \% 1633 \mathrm{a}$ & 1221.1 & 50.9 & 240 & 75.2 & 5.28 & vert \\
\hline 57 & $0.2 \% \mathrm{Cs}_{2} \mathrm{CO}_{3}$ & 1139 & 51.0 & 216 & & 0.86 & vert \\
\hline 58 & $0.2 \% \mathrm{Cs}_{2} \mathrm{CO}_{3}$ & 1173.3 & 76.3 & 240 & 75.2 & 7.35 & vert \\
\hline 59 & $\mathrm{C}_{2} \mathrm{CO}_{3}$ & 1174.3 & 50.9 & 120 & 75.3 & 3.22 & horiz \\
\hline 60 & $0.2 \% \mathrm{Cs}_{2} \mathrm{CO}_{3}$ & 1173.8 & 25.5 & 180 & 94.9 & 16.46 & vert \\
\hline 61 & $\mathrm{Cs}_{2} \mathrm{CO}_{3}$ & 1175.6 & 25.5 & 120 & 94.8 & 16.43 & horiz \\
\hline 62 & $0.2 \% \mathrm{Cs}_{2} \mathrm{CO}_{3}$ & 1221.5 & 76.3 & 180 & 74.7 & 7.67 & vert \\
\hline 63 & $\mathrm{C}_{2} \mathrm{CO}_{3}$ & 1223.3 & 51.0 & 120 & 75.5 & 3.54 & horiz \\
\hline 64 & $0.2 \% \mathrm{Cs}_{2} \mathrm{CO}_{3}$ & 1221.6 & 25.5 & 180 & 95.0 & 14.46 & vert \\
\hline 65 & $\mathrm{Cs}_{2} \mathrm{CO}_{3}$ & 1225.2 & 25.5 & 120 & 94.1 & 12.62 & horiz \\
\hline 66 & $0.2 \% \mathrm{Cs}_{2} \mathrm{CO}_{3}$ & 1272.1 & 76.3 & 180 & 74.9 & 7.38 & vert \\
\hline 67 & $\mathrm{C}_{2} \mathrm{CO}_{3}$ & 1273.3 & 76.3 & 120 & 75.2 & 5.03 & horiz \\
\hline 68 & $\mathrm{Cs}_{2} \mathrm{CO}_{3}$ & 1072.1 & 25.5 & 180 & 94.8 & 21.49 & horiz \\
\hline 69 & $0.2 \% \mathrm{Cs}_{2} \mathrm{CO}_{3} / 2 \%$ sieve $5 \mathrm{~A}$ & 1173 & 76.3 & 155 & & & vert \\
\hline 70 & $0.2 \% \mathrm{Cs}_{2} \mathrm{CO}_{3} / 2 \%$ sieve $5 \mathrm{~A}$ & 1173.4 & 25.5 & 240 & 94.8 & 12.56 & vert \\
\hline 71 & $\mathrm{C}_{2} \mathrm{CO}_{3}$ & 1073.5 & 76.3 & 120 & 75.5 & 5.07 & boriz \\
\hline 72 & $0.2 \% \mathrm{C}_{82} \mathrm{CO}_{3} / 2 \%$ sieve $5 \mathrm{~A}$ & 1173.4 & 76.3 & 180 & 75.1 & 7.72 & yert \\
\hline 73 & $\mathrm{Cs}_{2} \mathrm{CO}_{3}$ & 1174.3 & 76.3 & 170 & & & horiz \\
\hline 74 & $0.2 \% \mathrm{Cs}_{2} \mathrm{CO}_{3} / 2 \%$ sieve $5 \mathrm{~A}$ & 1225.3 & 76.3 & 180 & 74.9 & 5.47 & vert \\
\hline 75 & $\mathrm{Cs}_{2} \mathrm{CO}_{3}$ & 1176.2 & 76.3 & 180 & & & horiz \\
\hline 76 & $0.2 \% \mathrm{Cs}_{82} \mathrm{CO}_{3} / 2 \%$ sieve $5 \mathrm{~A}$ & 1226.2 & 25.5 & 180 & 95.0 & 16.58 & vert \\
\hline 77 & $\mathrm{Cs}_{2} \mathrm{CO}_{3}$ & 1173.9 & 76.3 & 180 & 75.0 & 6.52 & horiz \\
\hline 80 & $0.2 \% \mathrm{Cs}_{2} \mathrm{CO}_{3} / 2 \%$ sieve $5 \mathrm{~A}$ & 1273.7 & 51.0 & 180 & 75.2 & 3.72 & vert \\
\hline 81 & $\mathrm{Cs}_{2} \mathrm{CO}_{3}$ & 1174.6 & 51.0 & 180 & 76.2 & 6.13 & horiz \\
\hline 82 & $\mathrm{Cs}_{2} \mathrm{CO}_{3}$ & 1172.6 & 25.5 & 180 & 75.6 & 2.28 & horiz \\
\hline 83 & $\mathrm{Cs}_{2} \mathrm{CO}_{3}$ & 1176.6 & 15.3 & 180 & 74.8 & 1.15 & horiz \\
\hline 84 & $0.2 \% \mathrm{Cs}_{2} \mathrm{CO}_{3} / 2 \% \mathrm{SiO}_{2}$ & 1173 & 25.5 & 120 & & & horiz \\
\hline 85 & $0.2 \% \mathrm{Cs}_{2} \mathrm{CO}_{3} / 2 \% \mathrm{SiO}_{2}$ & 1174.2 & 51.0 & 240 & & & vert \\
\hline 86 & $\mathrm{Cs}_{2} \mathrm{CO}_{3}$ & 1174.2 & 10.2 & 180 & 76.2 & 0.84 & horiz \\
\hline 87 & $0.2 \% \mathrm{Cs}_{2} \mathrm{CO}_{3} / 2 \% \mathrm{SiO}_{2}$ & 1173.7 & 25.5 & 180 & 94.7 & 14.25 & vert \\
\hline 88 & $\mathrm{Cs}_{2} \mathrm{CO}_{3}$ & 1173.3 & 5.3 & 180 & 75.3 & 0.31 & horiz \\
\hline 89 & $0.2 \% \mathrm{Cs}_{2} \mathrm{CO}_{3} / 2 \% \mathrm{SiO}_{2}$ & 1173 & 25.6 & 180 & & & vert \\
\hline 90 & $0.2 \% \mathrm{C}_{82} \mathrm{CO}_{3} / 2 \% \mathrm{SiO}_{2}$ & 1173.5 & 25.5 & 180 & 95.3 & 17.73 & vert \\
\hline 91 & $0.2 \% \mathrm{Cs}_{2} \mathrm{CO}_{3} / 2 \% \mathrm{SiO}_{2}$ & 1174.4 & 76.3 & 180 & 74.5 & 6.18 & vert \\
\hline 92 & $0.2 \% \mathrm{Cs}_{2} \mathrm{CO}_{3} / 2 \% \mathrm{SiO}_{2}$ & 1224.5 & 76.3 & 180 & 75.1 & 5.99 & vert \\
\hline 93 & $0.2 \% \mathrm{Cs}_{2} \mathrm{CO}_{3} / 2 \% \mathrm{SiO}_{2}$ & 1221.9 & 25.5 & 180 & 95.1 & 16.29 & vert \\
\hline 94 & $\mathrm{C}_{2} \mathrm{CO}_{3}$ & 1173 & 49.0 & 210 & & & vert \\
\hline 95 & $\mathrm{C}_{2} \mathrm{CO}_{3}$ & 1124.3 & 76.3 & 180 & 75.1 & 3.41 & vert \\
\hline 96 & $\mathrm{Cs}_{2} \mathrm{CO}_{3}$ & 1120.4 & 25.5 & 180 & 95.0 & 4.61 & vert \\
\hline 97 & $\mathrm{C}_{2} \mathrm{CO}_{3}$ & 1172.0 & 76.3 & 180 & 75.1 & 3.23 & vert \\
\hline 98 & $\mathrm{C}_{2} \mathrm{CO}_{3}$ & 1169.6 & 25.5 & 180 & 94.7 & 5.00 & vert \\
\hline 99 & $\mathrm{Cs}_{2} \mathrm{CO}_{3}$ & 1220.9 & 76.3 & 180 & 74.5 & 2.92 & vert \\
\hline 100 & $\mathrm{Cs}_{2} \mathrm{CO}_{3}$ & 1269.2 & 76.3 & 182 & 75.2 & 2.83 & vert \\
\hline
\end{tabular}




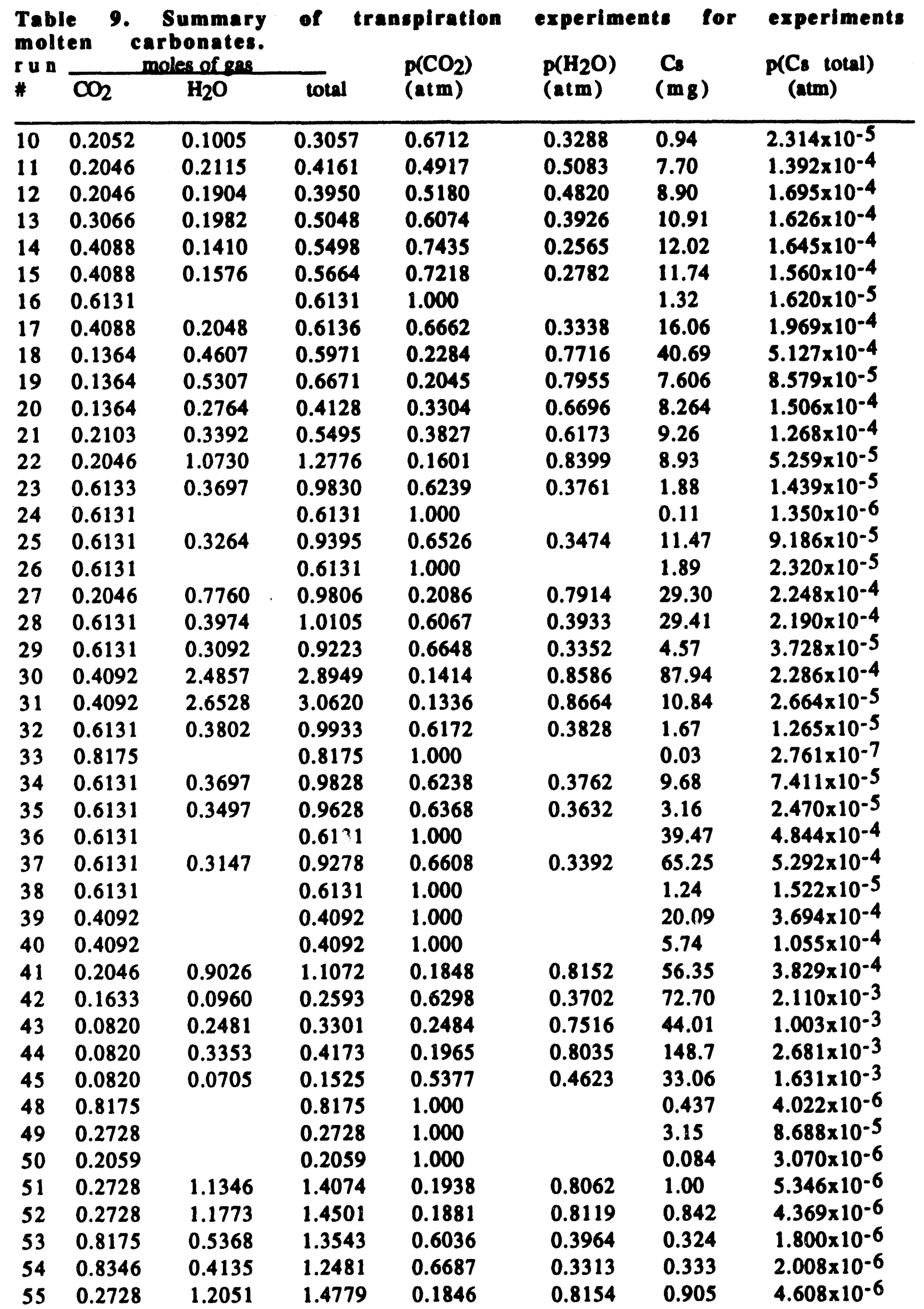




\begin{tabular}{|c|c|c|c|c|c|c|c|}
\hline \multirow{3}{*}{$\begin{array}{l}\text { Tabi } \\
\text { on } \\
r u \mathbf{n} \\
\#\end{array}$} & \multirow{2}{*}{\multicolumn{3}{|c|}{$\begin{array}{c}\text { 9. (cont.) Summary } \\
\text { molten carbonates. } \\
\text { moles of gas }\end{array}$}} & \multicolumn{2}{|c|}{ of transpiration } & experiments & \multirow{3}{*}{$\begin{array}{l}\text { for exper } \\
\text { p(Cs total) } \\
\text { (atm) }\end{array}$} \\
\hline & & & & \multirow{2}{*}{$\begin{array}{l}\mathrm{p}\left(\mathrm{CO}_{2}\right) \\
(\mathrm{atm})\end{array}$} & \multirow{2}{*}{$\begin{array}{l}\mathbf{p}\left(\mathrm{H}_{2} \mathrm{O}\right) \\
(\mathbf{a t m})\end{array}$} & \multirow{2}{*}{$\begin{array}{l}\text { Cs } \\
(\mathbf{m g})\end{array}$} & \\
\hline & $\infty_{2}$ & $\mathrm{H}_{2} \mathrm{O}$ & total & & & & \\
\hline 56 & 0.5447 & 0.2931 & 0.8378 & 0.6502 & 0.3498 & 0.426 & $3.826 \times 10^{-6}$ \\
\hline 57 & 0.4910 & 0.0477 & 0.5387 & 0.9115 & 0.0885 & 0.166 & $2.318 \times 10^{-6}$ \\
\hline 58 & 0.8175 & 0.4080 & 1.2255 & 0.6671 & 0.3329 & 0.279 & $1.713 \times 10^{-6}$ \\
\hline 59 & 0.2724 & 0.1787 & 0.4511 & 0.6039 & 0.3961 & 89.9 & $1.500 \times 10^{-3}$ \\
\hline 60 & 0.2046 & 0.9137 & 1.1183 & 0.1830 & 0.8170 & 0.472 & $3.176 \times 10^{-6}$ \\
\hline 61 & 0.1364 & 0.9120 & 1.0484 & 0.1301 & 0.8699 & 286.2 & $2.054 \times 10^{-3}$ \\
\hline 62 & 0.6131 & 0.4258 & 1.0389 & 0.5901 & 0.4099 & 0.818 & $5.924 \times 10^{-6}$ \\
\hline 63 & 0.2728 & 0.1965 & 0.4693 & 0.5813 & 0.4187 & 54.4 & $8.722 \times 10^{-4}$ \\
\hline 64 & 0.2046 & 0.8027 & 1.0073 & 0.2031 & 0.7969 & 0.969 & $7.238 \times 10^{-6}$ \\
\hline 65 & 0.1364 & 0.7005 & 0.8369 & 0.1631 & 0.8370 & 23.5 & $2.113 \times 10^{-4}$ \\
\hline 66 & 0.6131 & 0.4097 & 1.0228 & 0.5994 & 0.4006 & 0.801 & $5.892 \times 10^{-6}$ \\
\hline 67 & 0.4088 & 0.2792 & 0.6880 & 0.5942 & 0.4058 & 23.5 & $2.570 \times 10^{-4}$ \\
\hline 68 & 0.2046 & 1.1929 & 1.3975 & 0.1464 & 0.8536 & 2.09 & $1.125 \times 10^{-5}$ \\
\hline 69 & 0.5280 & & 0.5280 & 1.000 & & 0.126 & $1.796 \times 10^{-6}$ \\
\hline 70 & 0.2728 & 0.6972 & 0.9700 & 0.2812 & 0.7188 & 1.39 & $1.078 \times 10^{-5}$ \\
\hline 71 & 0.4088 & 0.2814 & 0.6902 & 0.5923 & 0.4077 & 0.661 & $7.206 \times 10^{-6}$ \\
\hline 72 & 0.6131 & 0.4285 & 1.0416 & 0.5886 & 0.4114 & 0.611 & $4.414 \times 10^{-6}$ \\
\hline 73 & 0.5791 & & 0.5791 & 1.000 & & 36.9 & $4.794 \times 10^{-4}$ \\
\hline 74 & 0.6131 & 0.3036 & 0.9167 & 0.6688 & 0.3312 & 0.348 & $2.856 \times 10^{-6}$ \\
\hline 75 & 0.6131 & & 0.6131 & 1.000 & & 55.5 & $6.811 \times 10^{-4}$ \\
\hline 76 & 0.2046 & 0.9203 & 1.1249 & 0.1819 & 0.8181 & 0.790 & $5.284 \times 10^{-6}$ \\
\hline 77 & 0.6131 & 0.3619 & 0.9750 & 0.6288 & 0.3712 & 196 & $1.512 \times 10^{-3}$ \\
\hline 80 & 0.4092 & 0.2065 & 0.6157 & 0.6646 & 0.3354 & 0.184 & $2.248 \times 10^{-6}$ \\
\hline 81 & 0.4092 & 0.3403 & 0.7495 & 0.5460 & 0.4540 & 106 & $1.064 \times 10^{-3}$ \\
\hline 82 & 0.2046 & 0.1266 & 0.3312 & 0.6178 & 0.3822 & 41.1 & $9.337 \times 10^{-4}$ \\
\hline 83 & 0.1226 & 0.0638 & 0.1864 & 0.6577 & 0.3423 & 27.4 & $1.106 \times 10^{-3}$ \\
\hline 84 & 0.1364 & & 0.1364 & 1.000 & & 0.050 & $2.758 \times 10^{-6}$ \\
\hline 85 & 0.5456 & & 0.5456 & 1.000 & & 0.051 & $7.033 \times 10^{-7}$ \\
\hline 86 & 0.0820 & 0.0466 & 0.1286 & 0.6376 & 0.3624 & 13.4 & $7.840 \times 10^{-4}$ \\
\hline 87 & 0.2046 & 0.7910 & 0.9956 & 0.2055 & 0.7945 & 0.462 & $3.492 \times 10^{-6}$ \\
\hline 88 & 0.0427 & 0.0172 & 0.0599 & 0.7129 & 0.2871 & 19.2 & $2.412 \times 10^{-3}$ \\
\hline 89 & 0.2052 & & 0.2052 & 1.000 & & 0.075 & $2.750 \times 10^{-6}$ \\
\hline 90 & 0.2046 & 0.9842 & 1.1888 & 0.1721 & 0.8279 & 0.770 & $4.874 \times 10^{-6}$ \\
\hline 91 & 0.6131 & 0.3430 & 0.9561 & 0.6413 & 0.3587 & 0.264 & $2.078 \times 10^{-6}$ \\
\hline 92 & 0.6131 & 0.3325 & 0.9456 & 0.6484 & 0.3516 & 0.433 & $3.445 \times 10^{-6}$ \\
\hline 93 & 0.2046 & 0.9042 & 1.1088 & 0.1845 & 0.8155 & 1.82 & $1.235 \times 10^{-5}$ \\
\hline 94 & 0.4588 & & 0.4588 & 1.000 & & 27 & $4.428 \times 10^{-4}$ \\
\hline 95 & 0.6131 & 0.1893 & 0.8024 & 0.7641 & 0.2359 & 46 & $4.313 \times 10^{-4}$ \\
\hline 96 & 0.2046 & 0.2559 & 0.4605 & 0.4443 & 0.5557 & 63 & $1.029 \times 10^{-3}$ \\
\hline 97 & 0.6131 & 0.1793 & 0.7924 & 0.7737 & 0.2263 & 113 & $1.073 \times 10^{-3}$ \\
\hline 98 & 0.2046 & 0.2775 & 0.4821 & 0.4244 & 0.5756 & 131 & $2.044 \times 10^{-3}$ \\
\hline 99 & 0.6131 & 0.1621 & 0.7752 & 0.7909 & 0.2091 & 222 & $2.155 \times 10^{-3}$ \\
\hline 100 & 0.6200 & 0.1571 & 0.7771 & 0.7978 & 0.2022 & 439 & $4.250 \times 10^{-3}$ \\
\hline
\end{tabular}


from the vertical apparatus, the exception shows agreement between both apparatuses. At $1173 \mathrm{~K}$, a flow rate test was conducted on the horizontal unit. A plot of flow rate versus the equilibrium constant for the generation of $\mathrm{CsOH}_{3}(\mathrm{~g})$ from $\mathrm{Cs}_{2} \mathrm{CO}_{3}(\mathrm{l})$ is given in Figure 7. At flow rates below about $10 \mathrm{~cm}^{3} / \mathrm{min}$, the data indicate that gaseous diffusion is a problem. However, higher flow rates seem to give good data. These data all fall at or near the data measured on the vertical unit. Although the horizontal unit clearly yields less accurate measurements than the vertical, the data obtained from it can still be used to support conclusions that follow.

\section{Concentration Effect}

The effect of cesium concentration on cesium volatility was obtained by comparing cesium volatility measurements from $13.9 \mathrm{wt} \% \mathrm{Cs}_{2} \mathrm{CO}_{3} / \mathrm{Na}_{2} \mathrm{CO}_{3}$ and $0.2 \mathrm{wt} \% \mathrm{Cs}_{2} \mathrm{CO}_{3} / \mathrm{Na}_{2} \mathrm{CO}_{3}$ with measurements from pure $\mathrm{Cs}_{2} \mathrm{CO}_{3}$. A plot of the logarithm of the equilibrium constant for the generation of $\mathrm{CsOH}(\mathrm{g})$ given by eqn (10) versus reciprocal temperature is given in Figure 8. Each set of data shows good linearity with matching slopes, indicating good consistency and reproducability. The data on $13.9 \mathrm{wt} \% \mathrm{Cs}_{2} \mathrm{CO}_{3} / \mathrm{Na}_{2} \mathrm{CO}_{3}$ and $0.2 \mathrm{wt} \% \mathrm{Cs}_{2} \mathrm{CO}_{3} / \mathrm{Na}_{2} \mathrm{CO}_{3}$ are reduced approximately by their mole fractions of cesium carbonate, i.e. by a factor of 0.0500 and 0.000652 , respectively. Thus, Raoult's law seems to be observed.

\section{Sulfate Effect}

The effect of sulfate on cesium volatility was obtained by comparing cesium volatility measurements from $10.2 \mathrm{wt} \% \mathrm{Cs}_{2} \mathrm{CO}_{3} / 22.5 \mathrm{wt} \% \mathrm{Na}_{2} \mathrm{SO}_{4}$ / $\mathrm{Na}_{2} \mathrm{CO}_{3}$ with measurements from $13.9 \mathrm{wt} \% \mathrm{Cs}_{2} \mathrm{CO}_{3} / \mathrm{Na}_{2} \mathrm{CO}_{3}$. A plot of the logarithm of the equilibrium constant for the generation of $\mathrm{CsOH}(\mathrm{g})$ given by eqn (10) versus reciprocal temperature is given in Figure 9 . With two exceptions, both of which are assumed to be spurious, the sulfate mixture shows a lower volatility than the carbonate only mixture. The reduction in volatility due to the presence of about $20 \mathrm{wt} \%$ sulfate is just under a factor of 2. The same reduction in volatility is assumed to occur at lower concentrations of cesium in the carbonate based mixture. 


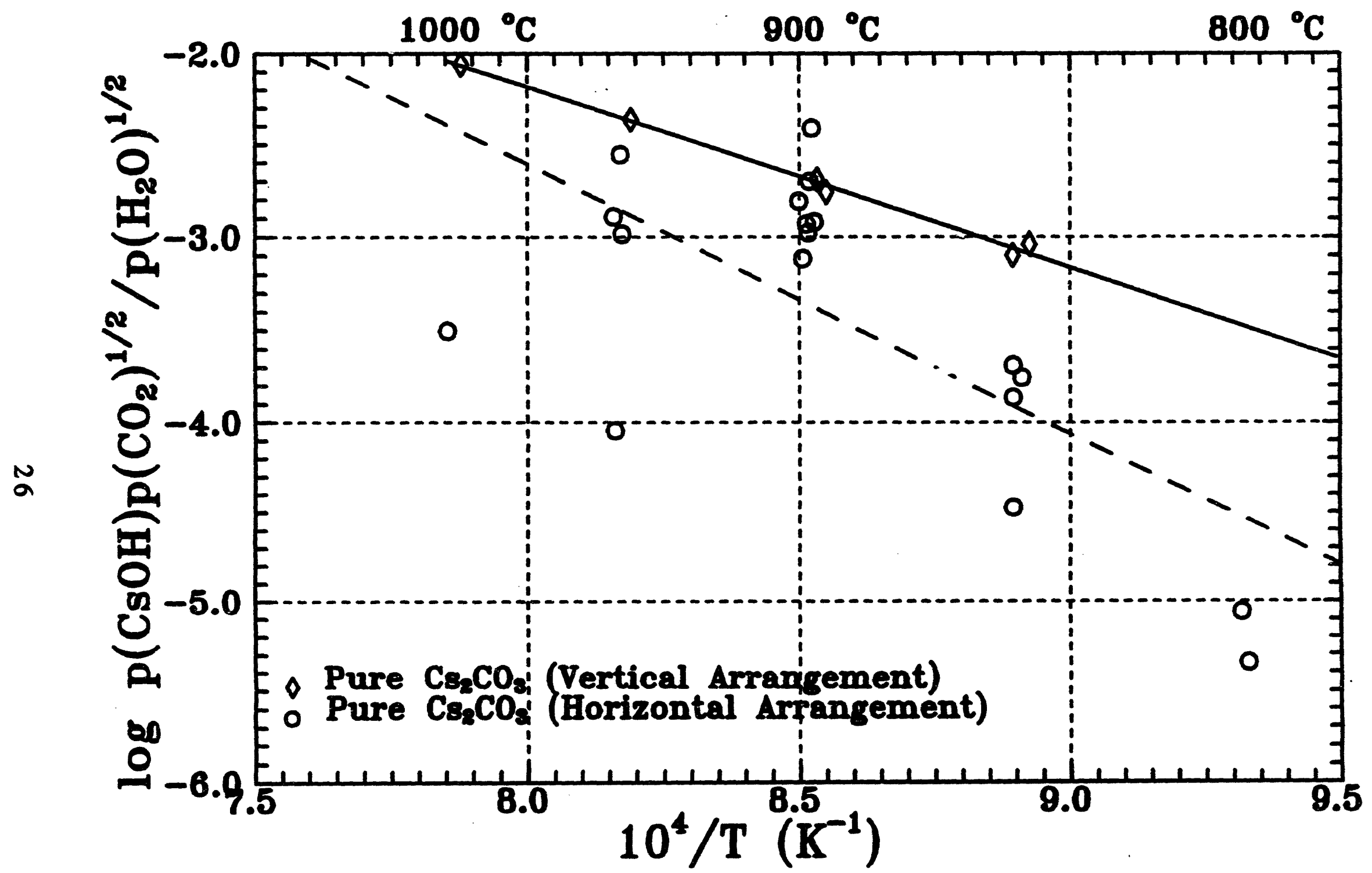

Figure 5. Plot showing $\log \mathrm{p}\left(\mathrm{C}_{8} \mathrm{OH}\right) \mathrm{p}\left(\mathrm{CO}_{2}\right)^{1 / 2} / \mathrm{p}\left(\mathrm{H}_{2} \mathrm{O}\right)^{1 / 2}$ as a function of $10^{4} / \mathrm{T}$ for experiments on pure $\mathrm{Cs}_{2} \mathrm{CO}_{3}$ conducted in the horizontal and vertical apparatuses. 


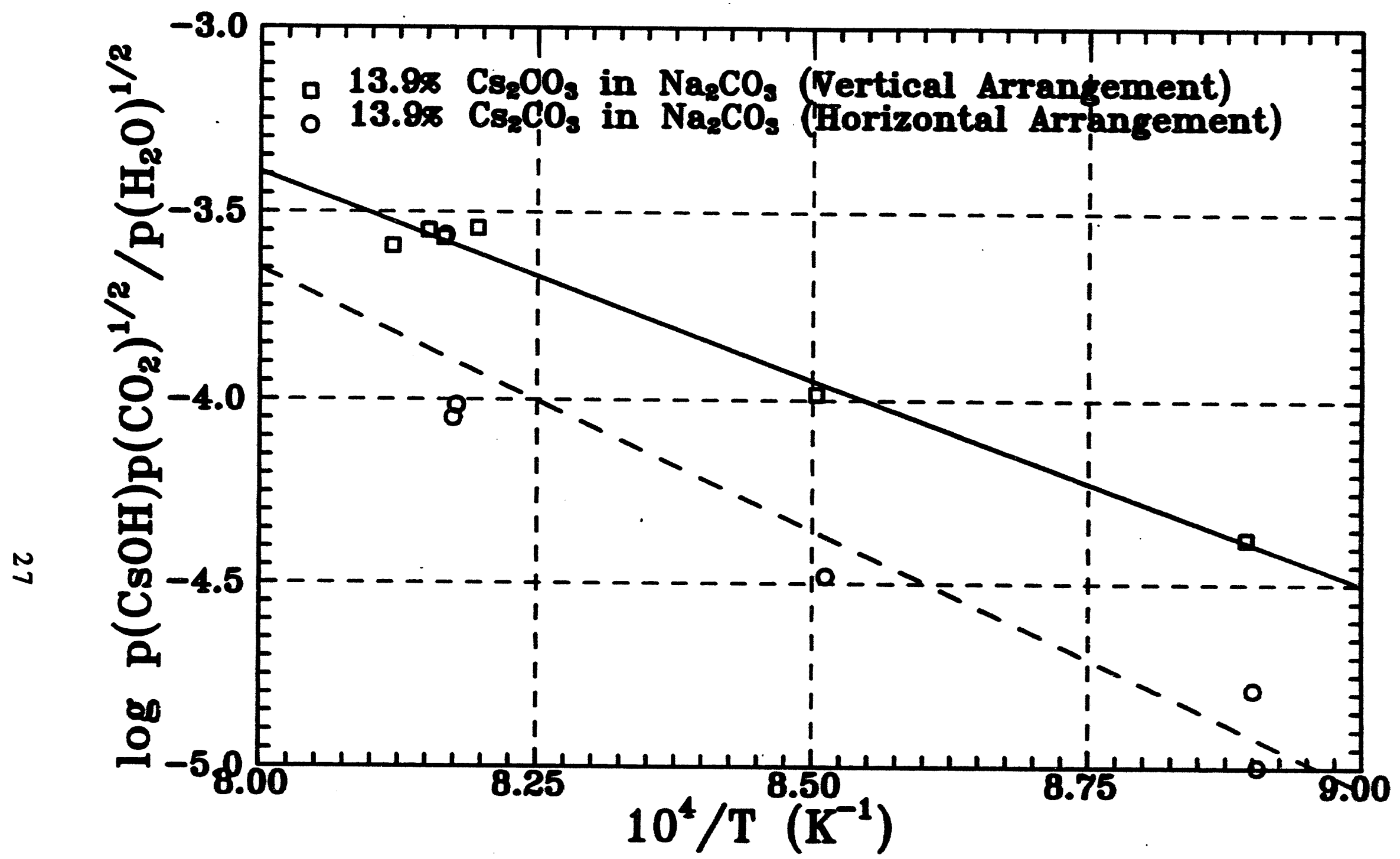

Figure 6. Plot showing $\log \mathrm{p}(\mathrm{CsOH}) p\left(\mathrm{CO}_{2}\right)^{1 / 2 / p}\left(\mathrm{H}_{2} \mathrm{O}\right)^{1 / 2}$ as a function of $104 / \mathrm{T}$ for experiments on $13.9 w t \% \mathrm{Cs}_{2} \mathrm{CO}_{3} / \mathrm{Na}_{2} \mathrm{CO}_{3}$ conducted in the horizontal and vertical apparatuses. 


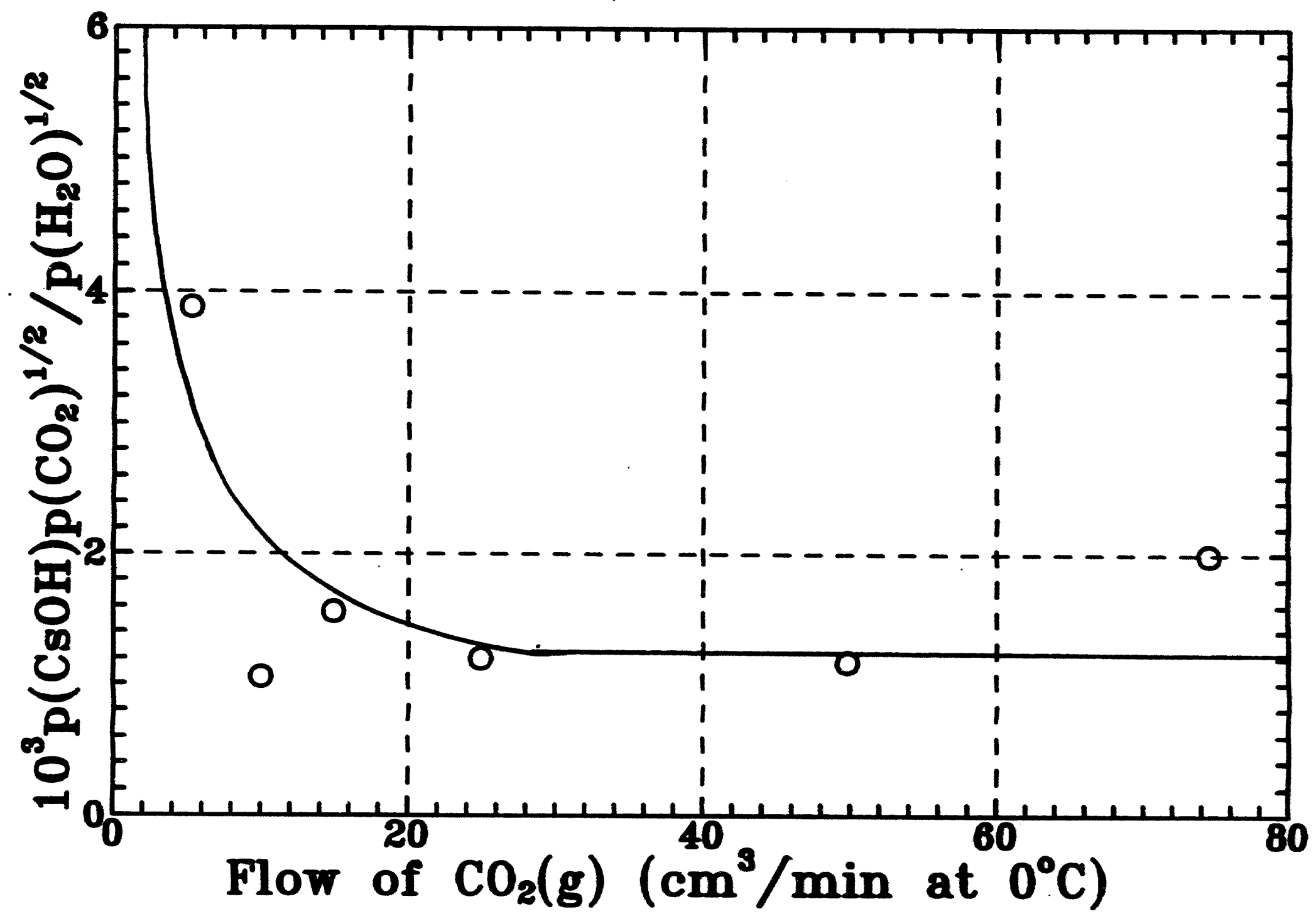

Figure 7. Plot showing $\left[\mathrm{p}(\mathrm{CsOH}) \mathrm{p}\left(\mathrm{CO}_{2}\right)^{1 / 2 / p}\left(\mathrm{H}_{2} \mathrm{O}\right) 1 / 2\right] \times 10^{3}$ as a function of $\mathrm{CO}_{2}$ (g) flow rate for experiments on pure $\mathrm{C}_{2} \mathrm{CO}_{3}$ conducted on the horizontal apparatus at $1173 \mathrm{~K}$. 


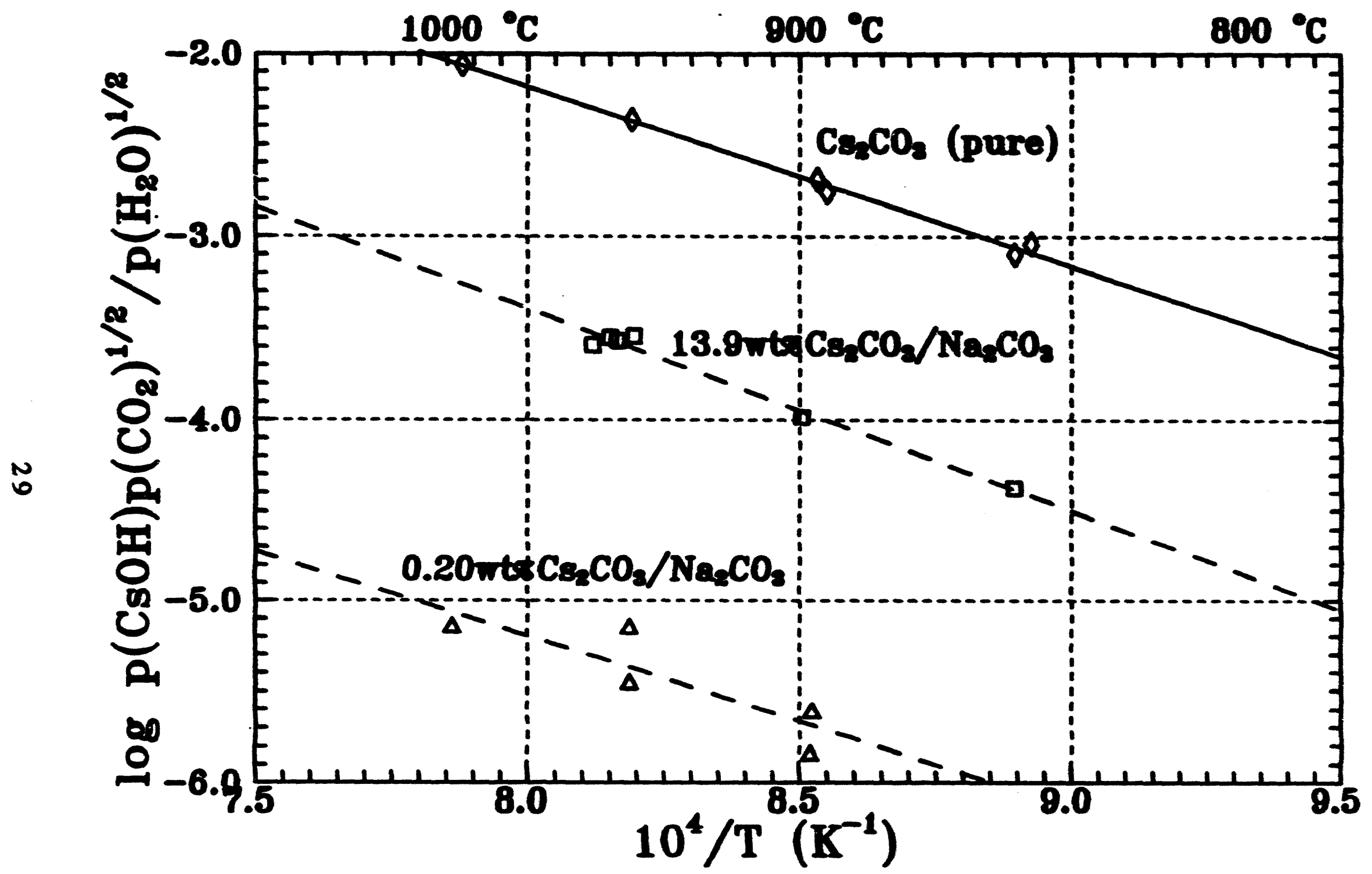

Figure 8. Plot showing $\log p(\mathrm{CsOH}) p\left(\mathrm{CO}_{2}\right)^{1 / 2 / p}\left(\mathrm{H}_{2} \mathrm{O}^{1 / 2}\right.$ as a function of $104 / \mathrm{T}$ for experimente on pure $\mathrm{C}_{2} \mathrm{CO}_{3}, 13.9$ wt\% $\mathrm{C}_{2} \mathrm{CO}_{3} / \mathrm{Na}_{2} \mathrm{CO}_{3}$, and 0.2 wt\% $\mathrm{C}_{2} \mathrm{CO}_{3} / \mathrm{Na}_{2} \mathrm{CO}_{3}$ conducted on the vertical apparates. 


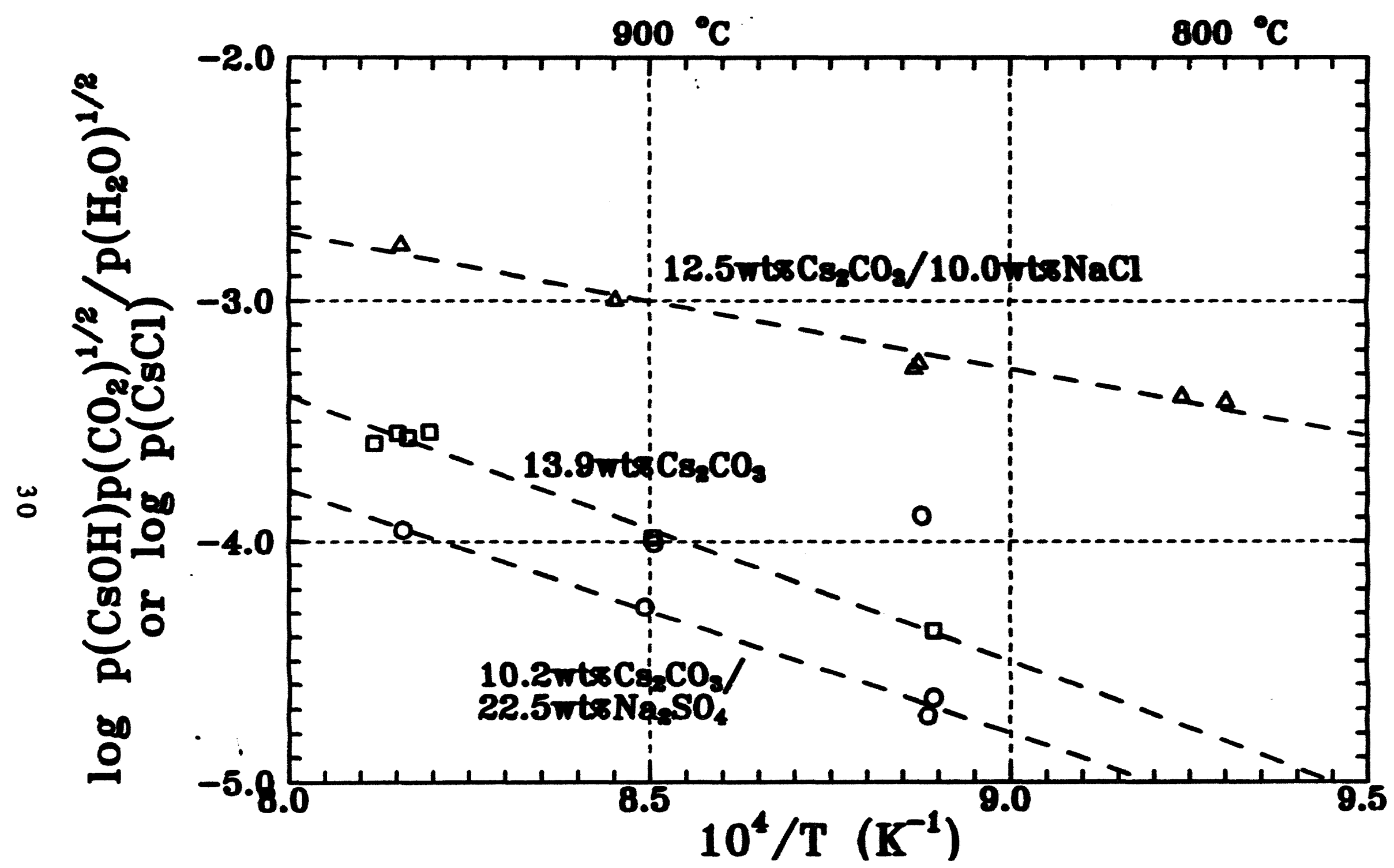

Figure 9. Plot showing $\log \mathrm{p}(\mathrm{C} \times \mathrm{OH}) \mathrm{p}\left(\mathrm{CO}_{2}\right)^{1 / 2 / p}\left(\mathrm{H}_{2} \mathrm{O}\right)^{1 / 2}$ a a function of $104 / \mathrm{T}$ for experiments on 13.9 wtw $\mathrm{C}_{2} \mathrm{CO}_{3} / \mathrm{Na}_{2} \mathrm{CO}_{3}$ and $10.2 \mathrm{wt} \% \mathrm{Cs}_{2} \mathrm{CO}_{3} /$ $22.5 w t \% \mathrm{Na}_{2} \mathrm{SO}_{4} / \mathrm{Na}_{2} \mathrm{CO}_{3}$ and $\mathrm{log}_{\mathrm{g}} \mathrm{p}(\mathrm{CaCn})$ as a function of $104 / \mathrm{T}$ for experiments on $12.5 w+\% \mathrm{C}_{2} \mathrm{CO}_{3} / 10.0 w t \% \mathrm{NaCl} / \mathrm{Na}_{2} \mathrm{CO}_{3}$ conducted on the vertical apparatus. 


\section{Chloride Bffect}

Tho effect of chloride on cesium volatility was obtained by comparing cosium volatility measurements from $12.5 w t \% \mathrm{Cs}_{2} \mathrm{CO}_{3} /$ $10.0 w t \% \mathrm{NaCl} / \mathrm{Na}_{2} \mathrm{CO}_{3}$ with mesuurements from $13.9 \mathrm{wt} \% \mathrm{C}_{2} \mathrm{CO}_{3} / \mathrm{Na}_{2} \mathrm{CO}_{3}$. The data are also compared in Figure 9. The volatility data are not affected by the $\mathrm{H}_{2} \mathrm{O}(\mathrm{g})$ pressure which implies, as expected, that $\mathrm{CsCl}(\mathrm{g})$ is the major vapor species. In Figure 9, the equilibrium conatants for the generation of $\mathrm{C} 2 O H(8)$ above $13.9 w t \% \mathrm{C}_{2} \mathrm{CO}_{3} / \mathrm{Na}_{2} \mathrm{CO}_{3}$ are plottod as a function of reciprocal temperature and the logarithm of the equilibrium constants for the generation of $\mathrm{CaCl}(8)$ above $12.5 w t \% \mathrm{Cs}_{2} \mathrm{CO}_{3} f$ $10.0 \mathrm{wt} \% \mathrm{NaCl} / \mathrm{N}_{2} \mathrm{CO}_{3}$ given by eqn (11) aro plotted as a function of reciprocal temperature. The addition of the chloride increases the cesium volatility dramatically, about an order of magnitude at $1200 \mathrm{~K}$. The same increase in volatility from $\mathrm{CsCl}(8)$ is assumed to occur at lower concentrations of cesium in carbonate-chloride mixtures.

\section{Ash Bffect}

The effect of ash on cesium volatility was obtained by comparing volatility measurements from $0.42 w t \% \mathrm{Cs}_{2} \mathrm{O} / 2690,0.2 \mathrm{wt} \% \mathrm{Cs}_{2} \mathrm{CO}_{3} /$ $2.0 \mathrm{wt} \% 1633 \mathrm{a} / \mathrm{Na}_{2} \mathrm{CO}_{3}, 0.2 \mathrm{wt} \% \mathrm{Cs}_{2} \mathrm{CO}_{3} / 2.0 \mathrm{wt} \%_{\text {sieves }} \mathrm{A} / \mathrm{Na}_{2} \mathrm{CO}_{3}$, and $0.2 \mathrm{w} t \% \mathrm{Cs}_{2} \mathrm{CO}_{3} / 2.0 \mathrm{w} t \% \mathrm{SiO}_{2} / \mathrm{N}_{2} \mathrm{CO}_{3}$ with measurements from $0.2 \mathrm{wt} \% \mathrm{Cs}_{2} \mathrm{CO}_{3} / \mathrm{Na}_{2} \mathrm{CO}_{3}$. The data for the carbonate based systems are compared in Figure 10. Within the experimental error, 2.0 wt\% of 1633a ash, molecular sieve $5 A$, or silica seem to have no effect on cesium volatility. However, the data for the molecular sieve seem to show a trend with time. In these experiments, the low-temperature runs were completed first and the high-temperature runs were completed last. The low-temperature rune lie above the curve given by $0.2 w+\% \mathrm{Cs}_{2} \mathrm{CO}_{3} / \mathrm{Na}_{2} \mathrm{CO}_{3}$ and the high-temperature runs lie at or below the curve given by $0.2 \mathrm{wt} \% \mathrm{Cs}_{2} \mathrm{CO}_{3} / \mathrm{Na}_{2} \mathrm{CO}_{3}$. This suggests that some interaction may occur at higher temperatures over a period of time, thus resulting in a lowered cesium volatility.

The data for $0.42 w t \% \mathrm{Cs}_{2} \mathrm{O} / 2690,0.2 w t \% \mathrm{Cs}_{2} \mathrm{CO}_{3} / \mathrm{Na}_{2} \mathrm{CO}_{3}$, and $0.2 w t \% \mathrm{Cs}_{2} \mathrm{CO}_{3} / 2.0 \mathrm{wt} \% 1633 \mathrm{a} / \mathrm{Na}_{2} \mathrm{CO}_{3}$ are compared in Figure 11. The volatility data for $0.42 w t \% \mathrm{Cs}_{2} \mathrm{O} / 2690$ lie about 3 orders of magnitude below the volatility data for $0.2 \mathrm{wt} \% \mathrm{C}_{2} \mathrm{CO}_{3} / \mathrm{Na}_{2} \mathrm{CO}_{3}$ and $0.2 \mathrm{wt} \% \mathrm{C}_{2} \mathrm{CO}_{3} /$ $2.0 \mathrm{wt} \% 1633 \mathrm{a} / \mathrm{Na2} \mathrm{CO}_{3}$. Although no reduction in cesium volatility occurs for the $2 w t \%$ ash mixture, this data suggests that higher concentrations of ash in the carbonate melt could show a significant decrease in cesium 


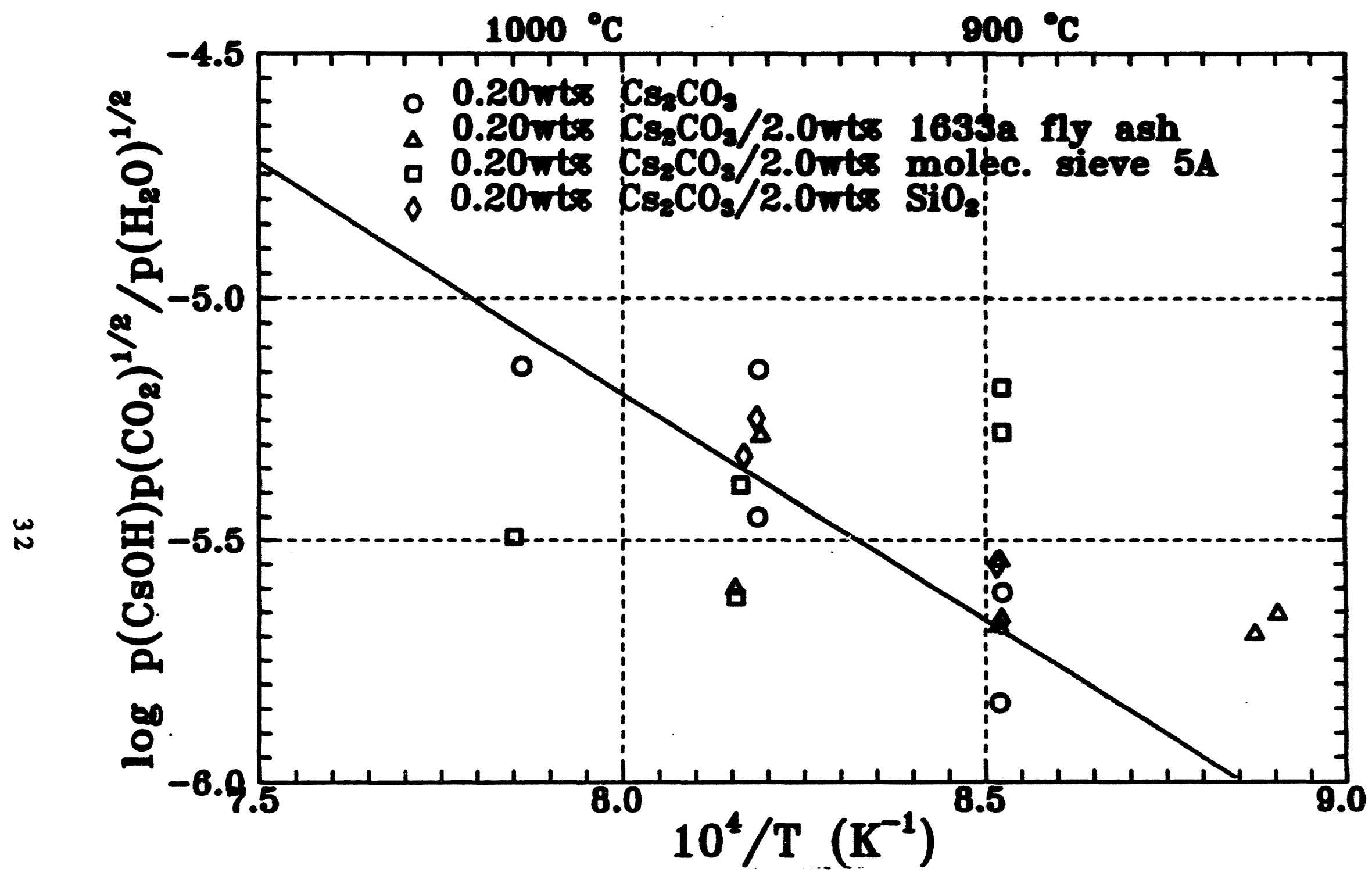

Figure 10. Plot showing $\log \mathrm{p}(\mathrm{C} 3 \mathrm{OH}) \mathrm{p}\left(\mathrm{CO}_{2}\right)^{1 / 2} / \mathrm{p}\left(\mathrm{H}_{2} \mathrm{O}\right)^{1 / 2}$ as a function of $10^{4} / \mathrm{T}$ for experiments on $0.2 \mathrm{wt} \mathrm{C}_{2} \mathrm{CO}_{3} / \mathrm{N}_{2} \mathrm{CO}_{3}, 0.2 \mathrm{wt} \% \mathrm{Cs}_{2} \mathrm{CO}_{3} /$ $2.0 \mathrm{wt} \% 1633 \mathrm{a} / \mathrm{Na}_{2} \mathrm{CO}_{3}, 0.2 \mathrm{wt} \% \mathrm{Cs}_{2} \mathrm{CO}_{3} / 2.0 \mathrm{wt} \%$ Sieve5A/Na2 $\mathrm{CO}_{3}$, and $0.2 \mathrm{wt} \% \mathrm{Cs}_{2} \mathrm{CO}_{3} / 2.0 \mathrm{wt} \% \mathrm{SiO}_{2} / \mathrm{Na}_{2} \mathrm{CO}_{3}$ conducted on the vertical apparatus. 


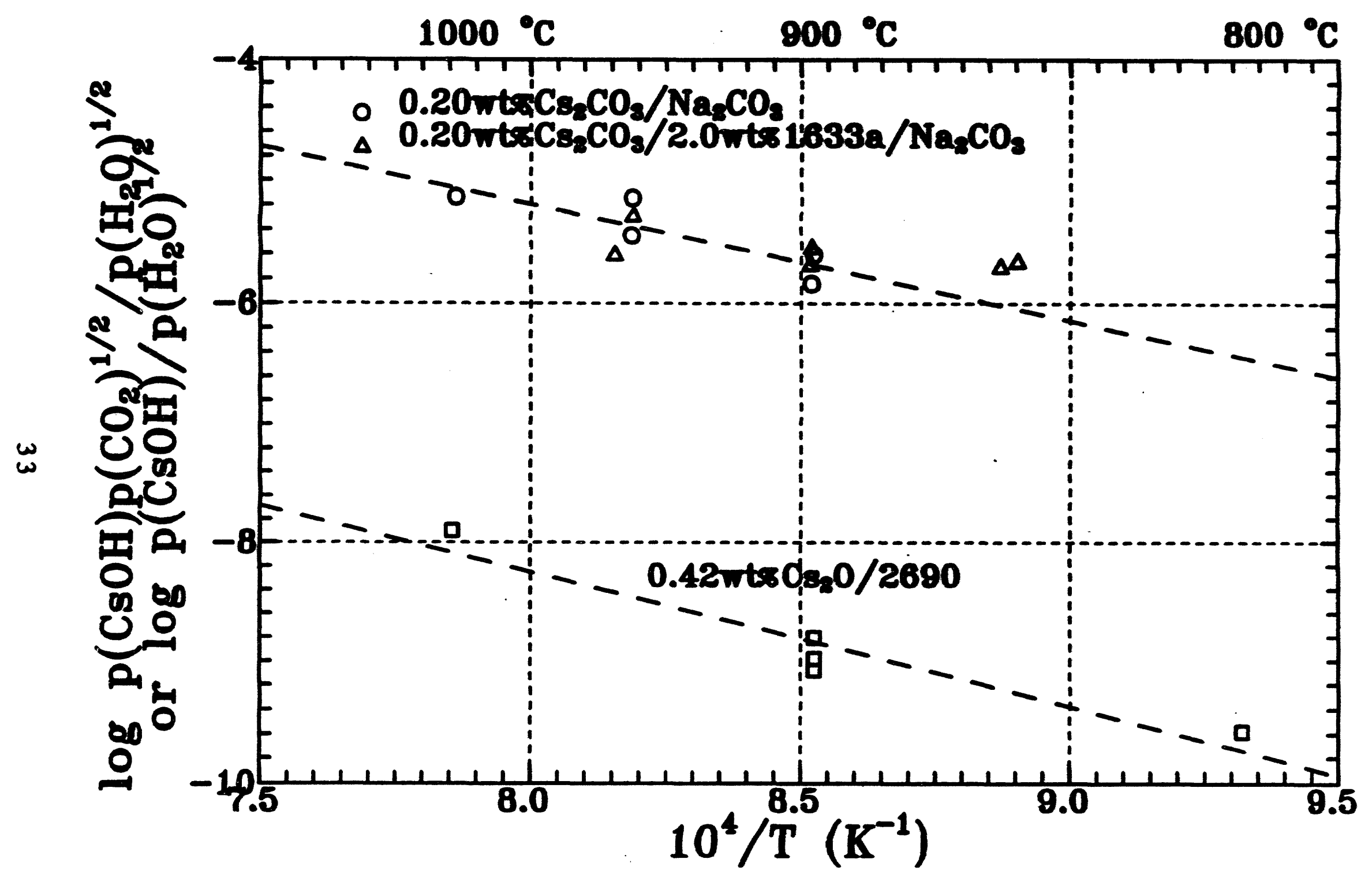

Figure 11. Plot showing $\log \mathrm{p}(\mathrm{CsOH}) \mathrm{p}\left(\mathrm{CO}_{2}\right)^{1 / 2 / p}\left(\mathrm{H}_{2} \mathrm{O}\right)^{1 / 2}$ as a function of $10^{4} / \mathrm{T}$ for experiments on $0.2 \mathrm{wt} \% \mathrm{Cs}_{2} \mathrm{CO}_{3} / \mathrm{Na}_{2} \mathrm{CO}_{3}$ and $0.2 \mathrm{wt} \% \mathrm{Cs}_{2} \mathrm{CO}_{3} /$ $2.0 \mathrm{wt} \% 1633 \mathrm{a} / \mathrm{Na}_{2} \mathrm{CO}_{3}$ conducted on the vertical apparatus and $\mathrm{log}$ $\mathrm{p}(\mathrm{CsOH}) / \mathrm{p}\left(\mathrm{H}_{2} \mathrm{O}\right)^{1 / 2}$ as a function of $104 / \mathrm{T}$ for experiments on $0.42 w t \% C_{82} 0 / 2690$ conducted on the horizontal apparatus. 
volatility. At only $2 w t \%$, the ash is probably completely dissolved in the carbonate melt and is thus ineffective in forming solid oxides with cesium.

Thermodynamic Parameters

Standard Entropy of $\mathrm{Cs}_{2} \mathrm{CO}_{3}(8)$ :

The standard entropy of $\mathrm{Cs}_{2} \mathrm{CO}_{3}(8)$ can be derived from the measured equilibrium constants for reaction (10) using pure $\mathrm{Cs}_{2} \mathrm{CO}_{3}$ in the vertical apparatus. The data taken in the horizontal apparatus are not used because of the large scatter. In order to calculate $\mathrm{S}_{2}^{\circ} 28$ for $\mathrm{Cs}_{2} \mathrm{CO}_{3}(8)$, the equilibrium constants are first converted to changes in free energy functions, $-\left(\Delta G^{\circ} T-\Delta H^{\circ} 298\right) / T$. The equilibrium constant is related to the change in free energy by

$$
\Delta G^{\circ} T=-R T \ln K_{\text {eq }}
$$

The change in enthalpy is calculated from data in the literature. The $\Delta \mathrm{H}^{\circ} \mathrm{f}, 298$ value for $\mathrm{Cs}_{2} \mathrm{CO}_{3}$ (8) was taken from Johnson and Gayer [7]. The $\Delta \mathrm{H}^{\circ} \mathrm{f}, 298$ values for $\mathrm{CO}_{2}(\mathrm{~g})$ and $\mathrm{H}_{2} \mathrm{O}(\mathrm{g})$ were taken from the JANAF tables [5], and the $\Delta \mathrm{H}^{\circ} \mathrm{f}, 298$ value for $\mathrm{CsOH}(\mathrm{g})$ was taken from Cordfunke and Konings [3]. From these data the $\Delta H^{\circ} \mathrm{r}, 298$ value for reaction (10) was calculated to be $234.62 \pm 3.02 \mathrm{~kJ} / \mathrm{mol}$. From the calculated change in free energy functions, the free energy functions for $\mathrm{Cs}_{2} \mathrm{CO}_{3}(\mathrm{l})$ were calculated. The free energy functions for $\mathrm{CO}_{2}(\mathrm{~g})$ and $\mathrm{H}_{2} \mathrm{O}(\mathrm{g})$ were taken from the JANAF tables [5], and the free energy functions for $\mathrm{CsOH}(\mathrm{g})$ were taken from Cordfunke and Konings [3]. The free energy function is given by

$$
-\left(G^{\circ} \mathrm{T}-\mathrm{H}^{\circ} 298\right) / \mathrm{T}=\mathrm{S}^{\circ} 298+\left(\mathrm{S}^{\circ} \mathrm{T}-\mathrm{S}^{\circ} 298\right)-\left(\mathrm{H}^{\circ} \mathrm{T}-\mathrm{H}^{\circ} 298\right) / \mathrm{T}
$$

where

$$
\begin{gathered}
S^{\circ} \mathrm{T}-\mathrm{S}^{\circ} 298=298 \int^{1061}(\mathrm{Cp}(\mathrm{s}) / \mathrm{T}) \mathrm{dT}+\Delta \mathrm{H}^{\circ} \mathrm{fus}_{\mathrm{fu}} / 1061 \\
+1061 / \mathrm{T}(\mathrm{Cp}(1) / \mathrm{T}) \mathrm{dT}
\end{gathered}
$$

and

$$
\mathrm{H}^{\circ} \mathrm{T}-\mathrm{H}^{\circ} 298=298 \int 1061 \mathrm{Cp}(\mathrm{s}) \mathrm{dT}+\Delta \mathrm{H}^{\circ} \text { fus }+1061 \int \mathrm{T} \mathrm{Cp}(\mathrm{l}) \mathrm{dT} .
$$


Table 10. Derivation of the standard entropy for $\mathrm{Cs}_{2} \mathrm{CO}_{3}(\mathrm{~s})$ from the equilibrium constants measured for the reaction.

$$
1 / 2 \mathrm{Cs}_{2} \mathrm{CO}_{3}(\mathrm{l})+1 / 2 \mathrm{H}_{2} \mathrm{O}(\mathrm{g})=\mathrm{CsOH}(\mathrm{g})+1 / 2 \mathrm{CO}_{2}(\mathrm{~g})
$$

\begin{tabular}{|c|c|c|c|c|c|c|c|}
\hline $\begin{array}{l}\text { run } \\
\#\end{array}$ & $\begin{array}{c}T \\
(\mathbf{K})\end{array}$ & $\begin{array}{l}\text { reaction ( } \\
\text { Keq } \\
\text { (atm) }\end{array}$ & $\begin{array}{l}\text { (A) } \\
-\left(\Delta G^{\circ}-\Delta H^{\circ} 298\right) / T \\
\quad(J / m o l-K)\end{array}$ & $\begin{array}{c}\mathrm{Cs}_{2} \mathrm{CO}_{3}(\mathrm{l}) \\
-\left(\mathrm{G}^{\circ}-\mathrm{H}^{\circ} 298\right) / \mathrm{T} \\
(\mathrm{J} / \mathrm{mol}-\mathrm{K})\end{array}$ & $\begin{array}{l}\mathrm{S}^{\circ} \mathrm{T}-\mathrm{S}^{\circ} 298 \\
(\mathrm{~J} / \mathrm{mol}-\mathrm{K})\end{array}$ & $\begin{array}{l}\mathrm{H}^{\circ} \mathrm{T}-\mathrm{H}^{\circ} 298 \\
(\mathrm{~kJ} / \mathrm{mol})\end{array}$ & $\begin{array}{l}\mathrm{S}^{\circ} 298 \\
(\mathrm{~J} / \mathrm{mol}-\mathrm{K})\end{array}$ \\
\hline 95 & 1124.3 & $7.763 \times 10^{-4}$ & $\begin{array}{ll}-4 & 149.14\end{array}$ & 303.00 & 251.49 & 182.95 & 214.23 \\
\hline 96 & 1120.4 & $9.204 \times 10^{-4}$ & $.4 \quad 151.28$ & 298.41 & 250.81 & 182.19 & 210.21 \\
\hline 97 & 1172.0 & $1.984 \times 10^{-3}$ & -3 148.45 & 307.99 & 259.60 & 192.26 & 212.44 \\
\hline 98 & 1169.6 & $1.756 \times 10^{-3}$ & -3 147.84 & 309.02 & 259.20 & 191.79 & 213.80 \\
\hline 99 & 1220.9 & $4.191 \times 10^{-3}$ & $\begin{array}{ll}-3 & 146.73\end{array}$ & 315.04 & 267.57 & 201.80 & 212.76 \\
\hline 100 & 1269.2 & $8.443 \times 10^{-3}$ & -3 145.15 & 321.67 & 275.14 & 211.23 & $\frac{212.95}{212.73} \pm$ \\
\hline
\end{tabular}


$\mathrm{S}^{\circ} \mathrm{T}-\mathrm{S}^{\circ} 298$ and $\mathrm{H}^{\circ} \mathrm{T}-\mathrm{H}^{\circ} 298$ were then calculated for each experiment using the heat capacities for $\mathrm{Cs}_{2} \mathrm{CO}_{3}$ (8) given by Barin [6], the heat capacities for $\mathrm{Cs}_{2} \mathrm{CO}_{3}(1)$ given herein, and the heat of fusion given by Kobayasi, et al. [8]. By eqn (13), a $S^{\circ} 298$ value for each experiment was then obtained. The standard entropies for $\mathrm{Cs}_{2} \mathrm{CO}_{3}(8)$ derived in this manner are given in Table 10. Averaged the data yield $212.73 \pm 1.42$ $\mathrm{J} / \mathrm{mol}-\mathrm{K}$ for the $\mathrm{S}^{\circ} 298$ value of $\mathrm{Cs}_{2} \mathrm{CO}_{3}(\mathrm{~s})$.

\section{Activity Coefficients}

Using the definition in eqn (1), activity coefficients for $\mathrm{Cs}_{2} \mathrm{CO}_{3}(1)$ can be calculated. For purposes of comparison with the activity coefficient of $\mathrm{CsCl}(\mathrm{l})$, the activity coefficient of $\mathrm{C}_{2} \mathrm{CO}_{3}(\mathrm{l})$ is given per mole of cesium, i.e. as $x\left(\mathrm{C}_{22} \mathrm{CO}_{3}\right)^{1 / 2}$. For pure $\mathrm{Cs}_{2} \mathrm{CO}_{3}, 13.9 w \mathrm{w}_{6} \mathrm{Cs}_{2} \mathrm{CO}_{3} / \mathrm{Na}_{2} \mathrm{CO}_{3}, 0.2 \mathrm{wt} \% \mathrm{Cs}_{2} \mathrm{CO}_{3} /$ $\mathrm{Na}_{2} \mathrm{CO}_{3}$, and $10.2 \mathrm{wt} \% \mathrm{Cs}_{2} \mathrm{CO}_{3} / 22.5 \mathrm{wt} \% \mathrm{Na}_{2} \mathrm{SO}_{4} / \mathrm{Na}_{2} \mathrm{CO}_{3}$, the activity coefficients for $\mathrm{Cs}_{2} \mathrm{CO}_{3}$ are derived in Table 11. The equilibrium constant, $K_{e q}$, was calculated using thermodynamic data from the JANAF tables [5] for $\mathrm{CO}_{2}(\mathrm{~g})$ and $\mathrm{H}_{2} \mathrm{O}(\mathrm{g})$, from Cordfunke and Konings [3] for $\mathrm{CsOH}(\mathrm{g})$, and from Table 1 for $\mathrm{Cs}_{2} \mathrm{CO}_{3}(\mathrm{l})$. Over the temperature range of 1100 to $1300 \mathrm{~K}$, $\mathrm{K}$ eq for reaction (10) can be fitted to the equation

$$
\log \mathrm{K}_{\mathrm{eq}}=-0.9878\left(10^{4} / \mathrm{T}\right)+5.7170
$$

where

$$
\mathrm{K}_{\mathrm{eq}}=\mathrm{p}(\mathrm{CsOH}) \mathrm{p}\left(\mathrm{CO}_{2}\right)^{1 / 2 / p\left(\mathrm{H}_{2} \mathrm{O}\right)^{1 / 2}}
$$

and

$$
\mathrm{a}\left(\mathrm{Cs}_{2} \mathrm{CO}_{3}\right)^{1 / 2}=\gamma\left(\mathrm{Cs}_{2} \mathrm{CO}_{3}\right)^{1 / 2} \mathrm{y}^{+}\left(\mathrm{Cs}^{+}\right) \mathrm{y}^{-}\left(\mathrm{CO}_{3}^{2-}\right)^{1 / 2} \text {. }
$$

For pure $\mathrm{Cs}_{2} \mathrm{CO}_{3}, \gamma\left(\mathrm{Cs}_{2} \mathrm{CO}_{3}\right)^{1 / 2}$ was calculated to be $1.001 \pm 0.088$. For $13.9 w t \% \mathrm{Cs}_{2} \mathrm{CO}_{3} / \mathrm{Na}_{2} \mathrm{CO}_{3}, \gamma\left(\mathrm{Cs}_{2} \mathrm{CO}_{3}\right)^{1 / 2}$ was calculated to be $1.136 \pm 0.140$,

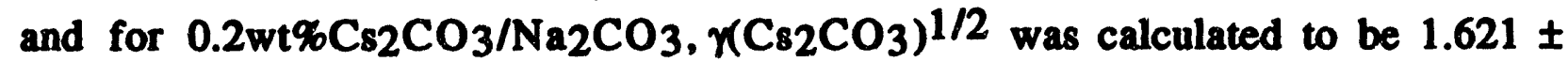
0.588 . The activity coefficients are near unity for the solutions, thus exhibiting almost ideal behavior. However, the activity coefficient of the solutions are slightly greater than unity implying a positive deviation from ideality, while the enthalpy of solution measurements in the literature [9] discussed earlier indicate a small negative deviation from ideality. At $1173 \mathrm{~K}$, a plot of $\log \mathrm{Keq}$ as a function of $\log \mathrm{x}^{+}\left(\mathrm{Cs}^{+}\right)$is given in Figure 12. 
Table 11. Activities and activity coefficients of $\mathrm{Cs}_{2} \mathrm{CO}_{3}$ in $\mathrm{Na}_{2} \mathrm{CO}_{3}$ and $\mathrm{Na}_{2} \mathrm{SO}_{4} / \mathrm{Na}_{2} \mathrm{CO}_{3}$ solutions.

$\left(\mathrm{K}^{\circ}\right.$ eq $\left.=\mathrm{p}(\mathrm{CsOH}) \mathrm{p}\left(\mathrm{CO}_{2}\right)^{1 / 2 / p}\left(\mathrm{H}_{2} \mathrm{O}\right) 1 / 2\right)$

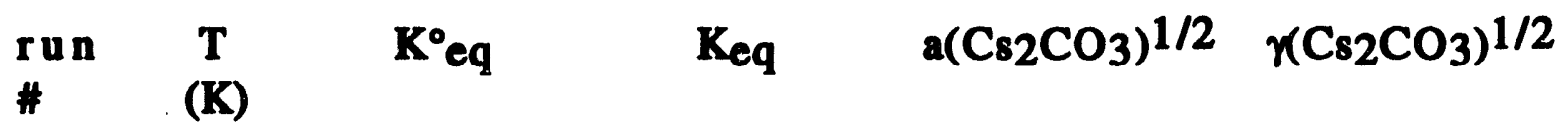

pure $\mathrm{Cs}_{2} \mathrm{CO}_{3}, \mathrm{y}^{+}\left(\mathrm{Cs}^{+}\right)=1.0000$

$95 \quad 1124.37 .763 \times 10^{-4} 8.494 \times 10^{-4}$

$96 \quad 1120.4 \quad 9.204 \times 10^{-4} \quad 7.908 \times 10^{-4}$

$97 \quad 1172.0 \quad 1.984 \times 10^{-3} \quad 1.951 \times 10^{-3}$

$98 \quad 1169.6 \quad 1.756 \times 10-3 \quad 1.875 \times 10^{-3}$

$99 \quad 1220.9 \quad 4.191 \times 10^{-3} \quad 4.245 \times 10^{-3}$

$100 \quad 1269.28 .443 \times 10^{-3} 8.566 \times 10^{-3}$

$13.9 w t \% \mathrm{Cs}_{2} \mathrm{CO}_{3}, \mathrm{y}^{+}\left(\mathrm{Cs}^{+}\right)=0.05001$

$14 \quad 1220.2 \quad 2.801 \times 10^{-4} 4.200 \times 10^{-3}$

$15 \quad 1231.7 \quad 2.512 \times 10^{-4} 4.994 \times 10^{-3}$

$17 \quad 1226.8 \quad 2.782 \times 10^{-4} 4.641 \times 10^{-3}$

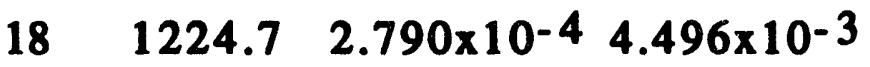

$19 \quad 1124.4 \quad 4.350 \times 10-5 \quad 8.510 \times 10^{-4}$

$20 \quad 1176.0 \quad 1.060 \times 10^{-4} 2.085 \times 10^{-3}$

$0.2 \mathrm{wt} \% \mathrm{Cs}_{2} \mathrm{CO}_{3}, \mathrm{y}^{+}\left(\mathrm{Cs}^{+}\right)=0.0006517$

$58 \quad 1173.3 \quad 2.425 \times 10^{-6} \quad 1.994 \times 10^{-3}$

$60 \quad 1173.8 \quad 1.503 \times 10-6 \quad 2.011 \times 10-3$

$62 \quad 1221.5 \quad 7.108 \times 10^{-6} \quad 4.284 \times 10^{-3}$

$64 \quad 1221.6 \quad 3.654 \times 10-6 \quad 4.291 \times 10^{-3}$

$66 \quad 1272.1 \quad 7.208 \times 10^{-6} 8.918 \times 10^{-3}$
0.9139

0.9139

1.1640

1.1640

1.0167

1.0167

0.9364

0.9364

0.9871

0.9871

0.9857

0.06668

1.3333

0.05031

1.0060

0.05995

1.1988

0.06204

0.05111

0.05075

1.2406

1.0220

1.0148

$1.1359 \pm 0.1403$
$0.001216 \quad 1.8659$

$0.0007476 \quad 1.1471$,

$0.001659 \quad 2.5456$

$0.0008516 \quad 1.3067$

$0.0008083 \quad 1.2403$

$1.6211 \pm 0.5880$

$10.2 w t \% \mathrm{Cs}_{2} \mathrm{CO}_{3} / 22.5 w t \% \mathrm{Na}_{2} \mathrm{SO}_{4}, \mathrm{y}^{+}\left(\mathrm{Cs}^{+}\right)=0.03793, \mathrm{y}^{-}\left(\mathrm{CO}_{3}^{2-}\right)=0.8076$
$21 \quad 1175.6 \quad 9.984 \times 10^{-5} \quad 2.071 \times 10^{-3}$
0.04820
$1.4141^{*}$
$22 \quad 1124.5 \quad 2.296 \times 10^{-5} \quad 8.525 \times 10^{-4}$
0.02693
0.7901
$23 \quad 1125.4 \quad 1.853 \times 10-5 \quad 8.666 \times 10^{-4}$
0.02139
0.6275
$25 \quad 1126.5 \quad 1.259 \times 10^{-4} 8.842 \times 10^{-4}$
0.1424
$4.1776 *$
$27 \quad 1225.7 \quad 1.154 \times 10^{-4} 4.565 \times 10^{-3}$
0.02529
0.7419
$29 \quad 1177.4 \quad 5.250 \times 10^{-5} \quad 2.134 \times 10^{-3}$
0.02461
0.7220
*runs not included in average
$0.7204 \pm 0.0682$ 


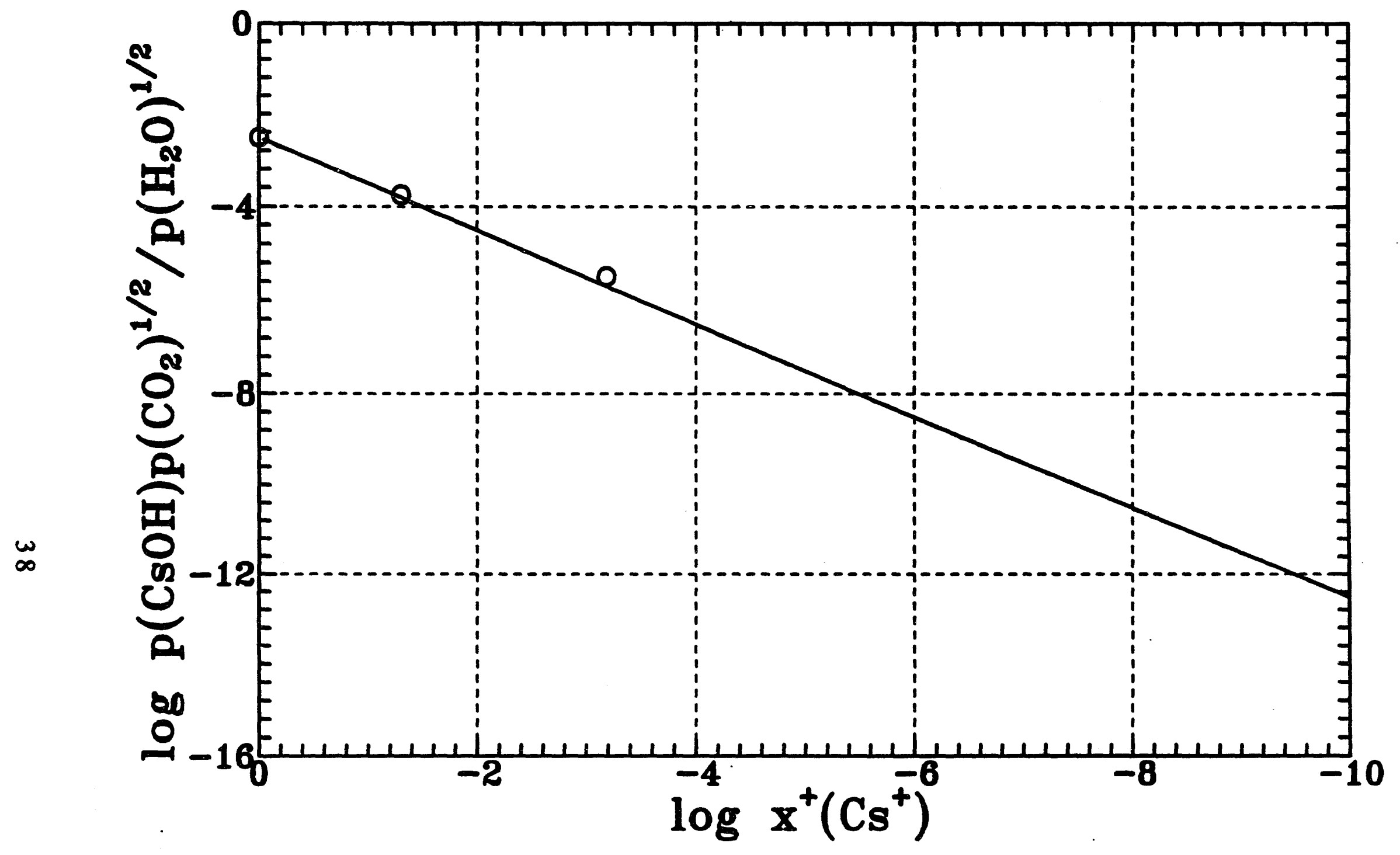

Figure 12. Plot showing $\log p(\mathrm{CsOH}) p\left(\mathrm{CO}_{2}\right)^{1 / 2 / p}\left(\mathrm{H}_{2} \mathrm{O}\right)^{1 / 2}$ as a function of $\log \mathrm{x}^{+}\left(\mathrm{Cs}^{+}\right)$at $1200 \mathrm{~K}$. The solid line is the curve expected from Raoult's law. 
Table 12. Activities and activity coefficients of $\mathrm{CsCl}$ in $\mathrm{NaCl} / \mathrm{Na}_{2} \mathrm{CO}_{3}$ solutions. $\left(\mathrm{K}^{\circ} \mathrm{eq}=\mathrm{p}(\mathrm{CsCl})\right)$

$\begin{array}{llllll}\text { run } & \mathbf{T} & \mathrm{K}^{\circ} \text { eq } & \mathrm{K}_{\text {eq }} & \mathbf{a}(\mathrm{CsCl}) & \boldsymbol{\gamma}(\mathrm{CsCl})\end{array}$

\begin{tabular}{cccccc}
\hline $12.5 w t \% \mathrm{Cs}_{2} \mathrm{CO} / 10.0 \mathrm{wt} \% \mathrm{NaCl}, \mathrm{y}^{+}\left(\mathrm{Cs}^{+}\right)=0.04502, \mathrm{y}^{-}\left(\mathrm{Cl}^{-}\right)=0.1000$ \\
36 & 1127.9 & $4.844 \times 10^{-4}$ & $1.612 \times 10^{-2}$ & 0.03004 & 6.6726 \\
37 & 1127.0 & $5.292 \times 10^{-4}$ & $1.591 \times 10^{-2}$ & 0.03325 & 7.3856 \\
39 & 1082.4 & $3.694 \times 10^{-4}$ & $8.087 \times 10^{-3}$ & 0.04568 & 10.1466 \\
41 & 1075.1 & $3.829 \times 10^{-4}$ & $7.195 \times 10^{-3}$ & 0.05323 & 11.8236 \\
43 & 1183.1 & $1.003 \times 10^{-3}$ & $3.433 \times 10^{-2}$ & 0.02922 & 6.4904 \\
45 & 1226.0 & $1.631 \times 10^{-3}$ & $5.852 \times 10^{-2}$ & 0.02787 & 6.1906 \\
& & & & & $8.1182 \pm 2.3167$
\end{tabular}


The solid line is the trend expected from Raoult's law and agrees well with the data. Neglecting the data from runs \#21 and \#29 since they deviate significantly from the other runs, $\gamma\left(\mathrm{C}_{8} 2 \mathrm{CO}_{3}\right)^{1 / 2}$ for $10.2 \mathrm{wt} \% \mathrm{Cs}_{2} \mathrm{CO} 3 / 22.5 \mathrm{wt} \% \mathrm{Na}_{2} \mathrm{SO}_{4} / \mathrm{Na}_{2} \mathrm{CO}_{3}$, was calculated to be $0.720 \pm$ 0.068 . (If the datum from run $\# 21$ was included, $\gamma\left(\mathrm{Cs}_{2} \mathrm{CO}_{3}\right)^{1 / 2}$ was calculated to be $0.859 \pm 0.316$.) Thus, a solution containing sulfate exhibits a small negative deviation from ideality.

Using the definition in eqn (3), the activity coefficient of $\mathrm{CsCl}(1)$ can be calculated. For $12.5 \mathrm{wt} \% \mathrm{Cs}_{2} \mathrm{CO}_{3} / 10.0 \mathrm{wt} \% \mathrm{NaCl} / \mathrm{Na}_{2} \mathrm{CO}_{3}$, the activity coefficients are derived in Table 12 . Keq was calculated using the free energy functions for $\mathrm{CsCl}(\mathrm{l})$ and $\mathrm{CsCl}(\mathrm{g})$ and the $\Delta \mathrm{H}^{\circ} \mathrm{f}, 298$ value for $\mathrm{CsCl}(\mathrm{l})$ given in the JANAF tables [5]. The $\Delta \mathrm{H}^{\circ} \mathrm{f}, 298$ value for $\mathrm{CsCl}(\mathrm{g})$ was based on data summarized in the JANAF tables [5] for the vaporization reaction

$$
\mathrm{CsCl}(1)=\operatorname{CsCl}(g) \text {. }
$$

The selected $\Delta \mathrm{H}^{\circ} \mathrm{f}, 298$ value for $\mathrm{CsCl}(\mathrm{g})$ was $-248.42 \pm 1.58 \mathrm{~kJ} / \mathrm{mol}$. Over the temperature range of 1100 to $1300 \mathrm{~K}, \mathrm{Keq}$ for reaction (11) can be fitted to the equation

$$
\log \mathrm{K}_{\text {eq }}=-0.7848\left(10^{4} / \mathrm{T}\right)+5.1670
$$

where

$$
\mathrm{K}_{\mathrm{eq}}=\mathrm{p}(\mathrm{CsCl}) / \mathrm{a}(\mathrm{CsCl})
$$

and

$$
\mathrm{a}(\mathrm{CsCl})=\gamma(\mathrm{CsCl}) y^{+}\left(\mathrm{Cs}^{+}\right) y^{-}\left(\mathrm{Cl}^{-}\right) \text {. }
$$

For $12.5 w t \% \mathrm{Cs}_{2} \mathrm{CO}_{3} / 10.0 \mathrm{wt} \% \mathrm{NaCl} / \mathrm{Na}_{2} \mathrm{CO}_{3}, \gamma(\mathrm{CsCl})$ was calculated to be $8.118 \pm 2.317$. Thus, a carbonate solution containing chloride exhibits a positive deviation from ideality. 
Application to Molten Salt Oxidation

$\mathrm{CsCl}(q)$ versus $\mathrm{CaOH}(q)$ Crose-Over Chloride Concentration

For the molten salt oxidizer, it is useful to know the cross-over chloride concentration for dilute solutions of cesium in the $\mathrm{NaCl}(1)$ $\mathrm{Na}_{2} \mathrm{CO}_{3}$ (l) system where the vapor pressures of $\mathrm{CsCl}(\mathrm{g})$ and $\mathrm{CsOH}(\mathrm{g})$ are equal. At higher chloride concentrations, $\mathrm{CsCl}(\mathrm{g})$ will be the major cesium vapor species and at lower chloride concentrations $\mathrm{CsOH}(\mathrm{g})$ will be the major cesium vapor species. The calculated cross-over chloride concentration will vary with the $\mathrm{CO}_{2}(\mathrm{~g})$ and $\mathrm{H}_{2} \mathrm{O}(\mathrm{g})$ pressures. For these calculations, however, the $\mathrm{CO}_{2}(\mathrm{~g})$ and $\mathrm{H}_{2} \mathrm{O}(\mathrm{g})$ pressures are taken to be equal and the reactive gas pressure effect cancels out. (See eqn (16)) Setting the vapor pressures of $\mathrm{CsOH}(\mathrm{g})$ and $\mathrm{CsCl}(\mathrm{g})$ given by eqne (16) and (17) equal, the following equation is obtained:

$$
\log \mathrm{y}^{-}\left(\mathrm{Cl}^{-}\right) /\left(1-\mathrm{y}^{-}\left(\mathrm{Cl}^{-}\right)\right)^{1 / 2}=-0.2030\left(10^{4} / \mathrm{T}\right)-0.1497
$$

where $\gamma\left(\mathrm{Cs}_{2} \mathrm{CO}_{3}\right)^{1 / 2}=1.621$ and $\gamma(\mathrm{CsCl})=8.118$. From eqn $(4)$, the anion mole fraction of chloride is related to the anion equivalent fraction of chloride by

$$
x^{-}\left(\mathrm{Cl}^{-}\right)=2 y^{-}\left(\mathrm{Cl}^{-}\right) /\left(1+y^{-}\left(\mathrm{Cl}^{-}\right)\right)
$$

For the molten salt oxidizer, the operating temperature is about $1200 \mathrm{~K}$. Thus, the cross-over point is calculated to be at the chloride equivalent composition, $y^{-}\left(\mathrm{Cl}^{-}\right)=1.431 \times 10^{-2}$, and the chloride mole fraction, $x^{-}\left(\mathrm{Cl}^{-}\right)=$ $2.821 \times 10^{-2}$. A similar calculation can be made to determine the crossover point of $\mathrm{NaCl}(\mathrm{g})$ over $\mathrm{NaOH}(\mathrm{g})$ in the $\mathrm{NaCl}(\mathrm{l})-\mathrm{Na}_{2} \mathrm{CO}_{3}(\mathrm{l})$ system. Using the data in the JANAF tables [5] and setting the pressures of $\mathrm{NaCl}(\mathrm{g})$ and $\mathrm{NaOH}(\mathrm{g})$ equal, the cross-over chloride composition at $1200 \mathrm{~K}$ is calculated to be at the chloride equivalent fraction, $\mathrm{y}^{-}\left(\mathrm{Cl}^{-}\right)=1.579 \times 10^{-2}$, and the chloride mole fraction, $x^{-}\left(\mathrm{Cl}^{-}\right)=3.109 \times 10^{-2}$, which is nearly the same as that calculated for cesium.

\section{Calculation of Percent Retention}

The thermodynamic data derived herein can now be used to calculate the percent retention of cesium in the molten salt oxidizer. The percent retention is defined as 
where $\mathrm{N}_{\mathrm{m}}\left(\mathrm{Cs}_{s}\right)$ is the total number of moles (or grams) of cesium remaining in the melt, $\mathrm{N}^{\circ} \mathrm{m}(\mathrm{Cs})$ is the initial number of moles (or grams) of cesium in the melt, and $\mathrm{Nf}\left(\mathrm{Cs}_{s}\right)$ is the number of moles (or grams) of cesium added in the feed. In order to calculate the percent retention, the mole fraction of cesium in the melt as a function of operating time is noeded. For convenience of notation the following definitions are made:

$$
\begin{aligned}
& a=\text { moles of } \mathrm{Cs} \text { added in feed per minute } \\
& b=\text { moles of } \mathrm{Cs} \text { carryover per minute total divided by } x^{+}\left(\mathrm{Cs}^{+}\right) \\
& c=\text { moles of } \mathrm{Na} \text { carryover per minute total } \\
& \mathrm{C}=\mathrm{N}^{\circ} \mathrm{m}(\mathrm{Na})=\text { total moles } \mathrm{Na} \text { in melt initial } \\
& t=\text { time in minutes } \\
& x^{\circ}=\mathrm{x}^{\circ+}\left(\mathrm{Cs}^{+}\right)=\text {mole fraction initial of cesium in molt } \\
& x=x^{+}\left(\mathrm{Cs}^{+}\right)=\text {mole fraction of cesium in melt } \\
& b_{v}=\text { moles } \mathrm{Cs} \text { volatilized per minute from pure } \mathrm{Cs}_{2} \mathrm{CO}_{3}(1) \\
& \mathrm{C}_{\mathrm{a}}=\text { moles of } \mathrm{Na} \text { added per minute } \\
& \mathrm{C}_{\mathrm{v}}=\text { moles of } \mathrm{Na} \text { volatilized per minute from pure } \mathrm{Na}_{2} \mathrm{CO}_{3}(1) \\
& c=\text { moles of } \mathrm{Na} \text { entrained per minute }
\end{aligned}
$$

The total amount of cesium carryover per minute divided by the cesium mole fraction is given by

$$
b=b v+e
$$

and the total amount of sodium carryover per minute is given by

$$
c=c_{v}+e-c_{2}
$$

The cation mole fraction of cesium is given by

$$
x=N_{m}(C s) /\left[N_{m}(C s)+N_{m}(\mathrm{Na})\right]
$$

where

$$
N_{m}(C s)=N^{\circ} m(C s)+0 f_{t} a-b x d t
$$

and if $x$ is small

$$
N_{m}(\mathrm{Na})=N^{\circ} m(\mathrm{Na})-0 \int t \mathrm{t} d t
$$


Substitution of eqne (24) and (25) into oqn (23), assuming $x$ is small, yields

$$
x=\left[0 \int t a-b x d t\right] /\left[C-0 \int t c d t\right]
$$

Bqn (26) can be rewritten as the differential equation

$$
(C-c t) d x / d t+(b-c) x-a=0.0 \text {. }
$$

The solution to this equation is given as

$$
x=v+\left(x^{0}-v\right)(1+u)-w
$$

where

$$
\begin{aligned}
& u=c t((C-c t), \\
& v=a /(b-c),
\end{aligned}
$$

and

$$
w=(b-c) / c .
$$

If the net carryover of sodium is zero, i.e. $c=0$, then the solution to eqn (28) becomes

$$
x=v+\left(x^{\circ}-v\right) e^{-b t / C} .
$$

To calculate percent retention, $x$ is then converted to $\mathrm{N}_{\mathrm{m}}\left(\mathrm{C}_{8}\right), \mathrm{N}^{\circ} \mathrm{m}\left(\mathrm{Cs}_{8}\right)$, and $\mathrm{N}_{\mathrm{f}}(\mathrm{Cs})$ by the relationships

$$
\begin{aligned}
& N_{m}(C s)=(C-c t) x, \\
& N_{m}^{\circ}(C s)=C x,
\end{aligned}
$$

and

$$
\mathrm{N}_{f}(\mathrm{Cs})=\mathrm{at},
$$

and then substituted into eqn (20). In addition, the total number of moles of cesium carryover, $\mathrm{N}_{\mathrm{c}}(\mathrm{Cs})$, is given by 


$$
\mathrm{N}_{c}\left(C_{0}\right)=\mathrm{N}_{\mathrm{m}}\left(\mathrm{C}_{0}\right)+\mathrm{N}_{\mathrm{f}}\left(\mathrm{C}_{0}\right)-\mathrm{N}_{\mathrm{m}}\left(\mathrm{C}_{0}\right)
$$

\section{Application to the Rockell MSO Procen}

Eqn (28) (or ogn (29) when $c=0$ ) can be uned to calculate the percent rotention of cosium in the molien salt oxidizer. The following are tuken to be the operating conditions: $p\left(\mathrm{H}_{2} \mathrm{O}\right)=\mathrm{p}\left(\mathrm{CO}_{2}\right)$ (approximately 0.1 atm esch), a total pressure of 1 atmoophere, a salt entrainment rate of 1 pound per day, a salt addition rate of 1 pound per day, an offges flow rate of 3.0 standard cubic foet por minute (SCFM) when wet, a ceaium foed rate of 3.0x10-7 Cs per day, bath size of about 12 pounds of salt, an initial cesium concentration equal to zero, and an operating temperature of 1200 K. Three different bath compositions are considered, pure $\mathrm{Na}_{2} \mathrm{CO}_{3}$. 20 wt\% $\mathrm{Na}_{2} \mathrm{SO}_{4}$ in $\mathrm{Na}_{2} \mathrm{CO}_{3}$, and 10.0 intw $\mathrm{NaCl}$ in $\mathrm{Na}_{2} \mathrm{CO}_{3}$.

From these conditions, the moles of $\mathrm{Na}$ physically entrained per

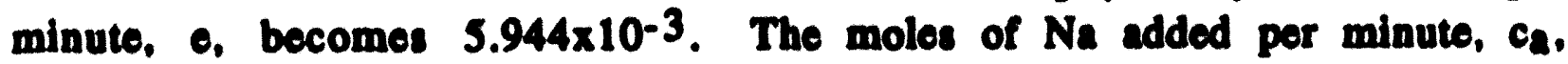
becomes 5.944x10-3. The total moles of $\mathrm{Na}$ initial in the melt, $\mathrm{C}$, becomes 102.7. (All are based on a pure $\mathrm{Na}_{2} \mathrm{CO}_{3}$ melt. The same $\mathrm{Na}$ physical entrainment rate, $\mathrm{Na}$ addition rate, and number of total initial moles of sodium are taken for the $20 \mathrm{wt} \% \mathrm{Na}_{2} \mathrm{SO}_{4}$ in $\mathrm{Na}_{2} \mathrm{CO}_{3}$ and the $10 \mathrm{wt} \% \mathrm{NaCl}$ in $\mathrm{Na}_{2} \mathrm{CO}_{3}$ melts) The cesium feed rate, a, in moles per minute becomes $1.568 \times 10^{-12}$. Using the ideal gas equation, the cesium and sodium volatilization rates in moles per minute are given by

$$
b x=3.518\left(\mathrm{p}\left(\mathrm{CrCl}_{8}\right)+\mathrm{p}\left(\mathrm{C}_{3} \mathrm{OH}\right)\right)
$$

and

$$
c=3.518(\mathrm{p}(\mathrm{NaCl})+\mathrm{p}(\mathrm{NaOH}))
$$

where the partial pressures of $\mathrm{CaCl}(\mathrm{g}), \mathrm{CsOH}(\mathrm{g}), \mathrm{NaCl}(\mathrm{g})$, and $\mathrm{NaOH}(\mathrm{g})$ are in atm and are given by

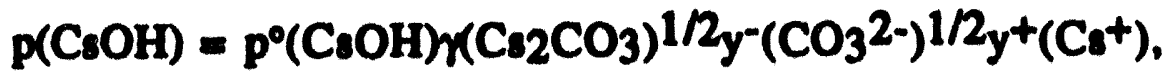

$$
\begin{aligned}
& p(\mathrm{CsCl})=p^{\circ}(\mathrm{CaCl})(\mathrm{CsCl}) y^{-}\left(\mathrm{Cl}^{-}\right) y^{+}\left(\mathrm{Cs}^{+}\right),
\end{aligned}
$$

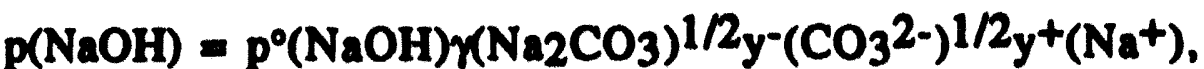

and 
and

$$
\mathrm{p}(\mathrm{NaCl})=\mathrm{p}^{\circ}(\mathrm{NaCl})(\mathrm{NaCl}) \mathrm{y}^{-}\left(\mathrm{Cl}^{-}\right) \mathrm{y}^{+}\left(\mathrm{Na}^{+}\right) \text {. }
$$

If the chloride concentration is much leas than 3 mols, then the cesium and sodium volatilization rate are dotormined solely from the partial pressures of CaOH(s) and $\mathrm{NaOH}(8)$, respectively. If the chloride concentration is much greater than 3 mol\%, then tho cesium and sodium volatilization rates are dotermined sololy from the partial pressures of $\mathrm{CrCl}(8)$ and $\mathrm{NaCl}(8)$, respectively. At $1200 \mathrm{~K}$, eque (16) and (17) and data in the JANAP tables [5] can be used to calculate the following: $\mathrm{p}^{\circ}(\mathrm{C} 2 \mathrm{OH})=$ $3.072 \times 10^{-3}, \mathrm{p}^{\circ}(\mathrm{CaCl})=4.258 \times 10^{-2}, \mathrm{p}^{\circ}(\mathrm{NaOH})=5.065 \times 10^{-5}$, and $\mathrm{p}^{\circ}(\mathrm{NaCl})=$ 3.182x10-3. The parnmotere, $y^{+}\left(\mathrm{Na}^{+}\right), x\left(\mathrm{Na2}_{2} \mathrm{CO}_{3}\right)^{1 / 2}$, and $x(\mathrm{NaCl})$, are taken to be equal to unity. The parameter, $y^{+}\left(\mathrm{Cs}^{+}\right)$, is equal to $x$.

If the starting composition of the bath is pure $\mathrm{Na}_{2} \mathrm{CO}_{3}$, then $y-\left(\mathrm{CO}_{3}^{2-}\right)^{1 / 2}$ is 1.000 and $\gamma\left(\mathrm{Cs}_{2} \mathrm{CO}_{3}\right)^{1 / 2}=1.621$. The $\mathrm{Cs}_{2}$ and $\mathrm{Na}$ volatilization rates, by and $c_{v}$, are calculated to be $1.752 \times 10^{-2} \mathrm{~mol} / \mathrm{min}$ and $1.782 \times 10^{-4} \mathrm{~mol} / \mathrm{min}$, respectively. If the starting composition of the bath is 20 wt\% $\mathrm{Na}_{2} \mathrm{SO}_{4}$ in $\mathrm{Na}_{2} \mathrm{CO}_{3}$, then $\mathrm{y}^{-}\left(\mathrm{CO}_{3}{ }^{-}\right)^{1 / 2}$ is 0.9180 and $\gamma\left(\mathrm{Cs}_{22} \mathrm{CO}_{3}\right)^{1 / 2}$ is 0.720 . The $\mathrm{Cs}$ and $\mathrm{Na}$ volatilization rates, by and $\mathrm{cv}$, are calculated to be $7.147 \times 10^{-3} \mathrm{~mol} / \mathrm{min}$ and $1.636 \times 10^{-4} \mathrm{~mol} / \mathrm{min}$, respectively. If the atarting composition of the bath is $10.0 \mathrm{wt} \% \mathrm{NaCl}$ in $\mathrm{Na}_{2} \mathrm{CO}_{3}$, then $\mathrm{y}^{-}\left(\mathrm{Cl}^{-}\right)$is 0.09153 and $\gamma(\mathrm{CsCl})$ is 8.118. The $\mathrm{Cs}$ and $\mathrm{Na}$ volatilization rates, bv and $c_{v}$, are calculated to be $1.113 \times 10^{-1} \mathrm{~mol} / \mathrm{min}$ and $1.024 \times 10^{-3} \mathrm{~mol} / \mathrm{min}$, respectively.

The percent retention as a function of time for each of the three melt compositions, $\mathrm{Na}_{2} \mathrm{CO}_{3}, 20 w t \% \mathrm{Na}_{2} \mathrm{SO}_{4} / \mathrm{Na}_{2} \mathrm{CO}_{3}$, and $10 \mathrm{wt} \% \mathrm{NaCl} / \mathrm{Na}_{2} \mathrm{CO}_{3}$, is shown in Figure 13. Over a 25 hour period, $20 w t \% \mathrm{Na}_{2} \mathrm{SO}_{4} / \mathrm{Na}_{2} \mathrm{CO}_{3}$ is calculated to have the best retention, about $91.0 \%$. $\mathrm{Na}_{2} \mathrm{CO}_{3}$ is calculated to have slightly worse retention, about $84.6 \%$, and $10 \mathrm{wt} \% \mathrm{NaCl} / \mathrm{Na}_{2} \mathrm{CO}_{3}$ is calculated to have very poor retention, about $47.5 \%$. The total amounts of cesium volatilized are calculated to be $1.53 \times 10^{-8} 8,3.58 \times 10^{-8} \mathrm{~g}$, and $1.56 \times 10-78$ and the total amounts of cesium physically entrained are calculated to be $1.28 \times 10^{-8} 8,1.22 \times 10^{-8} 8,8.31 \times 10^{-9} 8$ for $20 w t \% \mathrm{Na}_{2} \mathrm{SO}_{4} / \mathrm{Na}_{2} \mathrm{CO}_{3}, \mathrm{Na}_{2} \mathrm{CO}_{3}$, and $10 \mathrm{wt} \% \mathrm{NaCl} / \mathrm{Na}_{2} \mathrm{CO}_{3}$, respectively. 


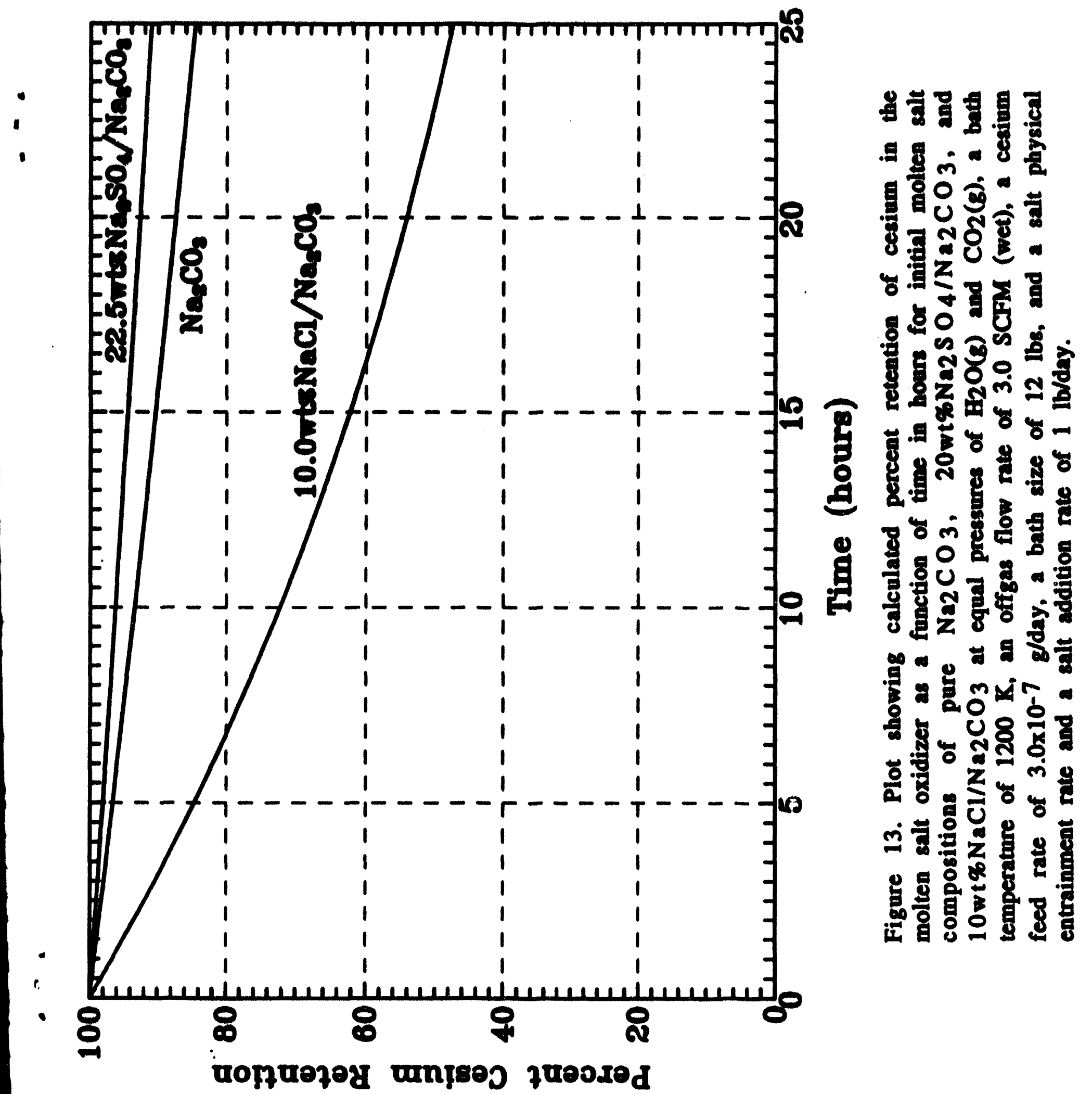


conditions except for the parameter which is varied are the same as given above and the time of operation is 25 hours. If the offgas flow rate is varied from 2.0 SCFM (wet) to 4.0 SCFM (wet), the percent cesium retention varies from $88.2 \%$ to $81.3 \%$. If the salt physical entrainment rate and addition rate vary from $0.5 \mathrm{lb} / \mathrm{day}$ to $1.5 \mathrm{lb} / \mathrm{day}$, the percent retention varies from 86.4\% to $82.9 \%$. If the operating temperature varies from 1125 to $1275 \mathrm{~K}$, the percent retention varies from $92.5 \%$ to $66.9 \%$. If the initial concentration of cesium in the bath is increased from zero, the percent retention is decreased from $84.6 \%$ and levels off at $71.0 \%$ for higher initial concentrations of cesium. If the cesium feed rate is varied, the percent retention remains constant at $84.6 \%$. Similar trends are expected for the $20 \mathrm{wt} \% \mathrm{Na}_{2} \mathrm{SO}_{4} / \mathrm{Na}_{2} \mathrm{CO}_{3}$ and $10 \mathrm{wt} \% \mathrm{NaCl} / \mathrm{Na}_{2} \mathrm{CO}_{3}$ baths.

\section{Summary and Conclusions}

Transpiration experiments have been applied to determine the volatility of cesium from molten carbonate mixtures at temperatures ranging from 1073 to $1373 \mathrm{~K}$. The major cesium vapor species is determined to be $\mathrm{CsOH}(8)$ except when greater than about 3 mol\% chloride is present in the melt, then the major cesium vapor species is $\mathrm{CsCl}(\mathrm{g})$. The activity coefficient of cesium carbonate, $\gamma\left(\mathrm{Cs}_{2} \mathrm{CO}_{3}\right)^{1 / 2}$, in solutions containing $\mathrm{Cs}_{2} \mathrm{CO}_{3}$ and $\mathrm{Na}_{2} \mathrm{CO}_{3}$ is determined to be near unity, 1.00 for pure $\mathrm{Cs}_{2} \mathrm{CO}_{3}$ and 1.62 for infinitely dilute concentrations of $\mathrm{Cs}_{2} \mathrm{CO}_{3}$. The addition of about $20 \mathrm{wt} \% \mathrm{Na}_{2} \mathrm{SO}_{4}$ to the bath reduces the cesium volatility by about a factor of 2 , and the addition of about $10 \mathrm{wt} \% \mathrm{NaCl}$ to the bath increases the cesium volatility by about a factor of 10 . The activity coefficient of cesium carbonate, $\gamma\left(\mathrm{Cs}_{2} \mathrm{CO}_{3}\right)^{1 / 2}$, in a solution containing $10.2 \mathrm{wt} \% \mathrm{C}_{2} \mathrm{CO}_{3}, 22.5 \mathrm{wt} \% \mathrm{Na}_{2} \mathrm{SO}_{4}$, and $67.3 \mathrm{wt} \% \mathrm{Na}_{2} \mathrm{CO}_{3}$ is determined to be 0.72 , and the activity coefficient of cesium chloride, $\gamma(\mathrm{CsCl})$, in a solution containing $12.5 \mathrm{wt} \% \mathrm{C}_{2} \mathrm{CO}_{3}, 10.0 \mathrm{wt} \% \mathrm{NaCl}$, and $77.5 \mathrm{wt} \% \mathrm{Na}_{2} \mathrm{CO}_{3}$ is determined to be 8.11. The addition of up to $2 \mathrm{wt} \%$ ash or silica has no effect on cesium volatility. The addition of $2 \mathrm{wt} \%$ molecular sieve $5 \mathrm{~A}$ seems to reduce the cesium volatility but only at higher temperatures, i.e. around $1373 \mathrm{~K}$.

The thermodynamic data have been applied to the Rockwell molten salt oxidizer. Taking the pressures of $\mathrm{H}_{2} \mathrm{O}(\mathrm{g})$ and $\mathrm{CO}_{2}(\mathrm{~g})$ to be equal, the total pressure to be 1 atmosphere, the salt entrainment rate and the salt addition rate to each be 1 pound per day, the offgas flow rate to be 3.0 standard cubic feet per minute (wet), the cesium feed rate to be $3.0 \times 10^{-7}$ grams per day, the bath size to be 12 pounds of salt, the initial cesium concentration to be equal to zero, and the operating temperature to be 
$1200 \mathrm{~K}$, the percent cesium retention for the salt compositions, pure $\mathrm{Na}_{2} \mathrm{CO}_{3}, 20 w t \% \mathrm{Na}_{2} \mathrm{SO}_{4}$ in $\mathrm{Na}_{2} \mathrm{CO}_{3}, 10 w t \% \mathrm{NaCl}$ in $\mathrm{Na}_{2} \mathrm{CO}_{3}$, are calculated as a function of operating time. The melt $20 \mathrm{wt} \% \mathrm{Na}_{2} \mathrm{SO}_{4} / \mathrm{Na}_{2} \mathrm{CO}_{3}$ is calculated to have the best cesium retention, about $91.0 \%$ after 25 hours of operation, and the melt $10 \mathrm{wt} \% \mathrm{NaCl} / \mathrm{Na}_{2} \mathrm{CO}_{3}$ is calculated to have the worst cesium retention, about 47.5\% after 25 hours of operation. Pure $\mathrm{Na}_{2} \mathrm{CO}_{3}$ was calculated to have a retention of about $84.6 \%$ after 25 hours of operation. The percent retention of cesium is increased by lower operating temperatures, by lower salt physical entrainment rates, by lower offgas flow rates, and by the presence of sulfate in the bath. However, the cesium feed rate has no effect on the calculated retention of cesium.

Acknowledgements

We gratefully acknowledge the assistance provided by Charles $\mathrm{H}$. Otto, Jr., for the cesium analyses. 
References

1. Molten Salt Oxidation Technology-Progress Report, DOE/ID/12584119, May, 1993.

2. L. F. Grantham, D. E. McKenzie, W. L. Richards, R. D. Oldenkamp, Molten Salt Combnstion of Radionctive Wastes, Proc. ERDA Air Clean Conf., 14, 17-35, 1976.

3. E. H. P. Cordfunke, R. J. M. Konings, P. E. Potter, G. Prins, and M. H. Rand, Thermochemical Dat for Reactor Materials and Eission Products, editors E. H. P. Cordfunke and R. J. M. Konings, North Holland, Amsterdam, 1990.

4. R. H. Lamoreaux and D. L. Hildebrand, "High Temperature Vaporization Behavior of Oxides. I. Alkali Metal Binary Oxides," J. Phys. Chem. Ref. Data, 13, 151-173 (1984).

5. M. W. Chase, Jr., C. A. Davies, J. R. Downey, Jr., D. J. Frurip, R. A. McDonald, and A. N. Syverund, JANAF Thermochemical Tables. 3rd Edition, Parts I and II (J. Phys Chem. Ref. Data, 14, 1985, Supplement No. 1), American Chemical Society and American Institute of Physics, New York, 1986.

6. I. Barin, Thermochemical Data of Pure Substances, VCH, New York, 1989.

7. G. K. Johnson and K. H. Gayer, "The Enthalpies of Solution and Formation of Cs2CO3," J. Chem. Thermo., 12, 705-708 (1980).

8. K. Kobayasi, N. Inoue, and T. Takano, "Specific Heat of Solid and Molten Phases, and Latent Heat of Fusion of Some Carbonates," Netsu Bussei, 6, 2-7 (1992).

9. B. K. Andersen and O. J. Kleppa, "Enthalpies of Mixing in Binary Liquid Alkali Carbonate Mixtures," Acta Chem. Scand. A, 30, 751-758 (1976).

10. T. Ostvold and O. J. Kleppa, "Enthalpies of Mixing in Binary Liquid Alkali Sulfate Mixtures," Acta Chem. Scand., 25, $919-929$ (1971).

11. L. S. Hersh and O. J. Kleppa, "Enthalpies of Mixing in Some Binary Liquid Halide Mixtures," J. Chem. Phys., 42, 1309-1322 (1965). 
12. Y. Dessureault, J. Sangster, and A. D. Pelton, "Coupled Phase DiagramThermodynamic Analysis of the 24 Binary Systems, A2CO3-AX and $\mathrm{A}_{2} \mathrm{SO}_{4}-\mathrm{AX}$ Where $\mathrm{A}=\mathrm{Li}$. Na, $\mathrm{K}$ and $\mathrm{X}=\mathrm{Cl}, \mathrm{F}, \mathrm{NO} 3, \mathrm{OH}, " \mathrm{~J}$. Phys. Chem. Ref. Data, 19, 1149-1178 (1990).

13. C. W. Bale and A. D. Pelton, "Coupled Phase Diagram and Thermodynamic Analysis of the 18 Binary Systems Formed Among $\mathrm{Li}_{2} \mathrm{CO}_{3}, \mathrm{~K}_{2} \mathrm{CO}_{3}, \mathrm{Na}_{2} \mathrm{CO}_{3}, \mathrm{LiOH}, \mathrm{KOH}, \mathrm{NaOH}, \mathrm{Li}_{2} \mathrm{SO}_{4}, \mathrm{~K}_{2} \mathrm{SO}_{4}$, and Na2SO4," CALPHAD, 6, 255-278 (1982).

14. F. D. Richardson and C. B. Alcock, "Chemical Equilibria," in Physiochemical Measurements at High Temperatures, edited by $J$. O'M. Bockris, J. L. White, and J. D. Mackenzie, Butterworths Sci. Publ., London, 1959, pp 135-170.

15. O. H. Krikorian, B. B. Ebbinghaus, M. G. Adamson, A. S. Fontes, Jr., D. L. Fleming, "Experimental Studies and Thermodynamic Modeling of Volatilities of Uranium, Plutonium, and Americium from Their Oxides and from Their Oxides Interacted with Ash," Lawrence Livermore National Laboratory Report, UCRL-ID-114774, Sept. 15, 1993. 

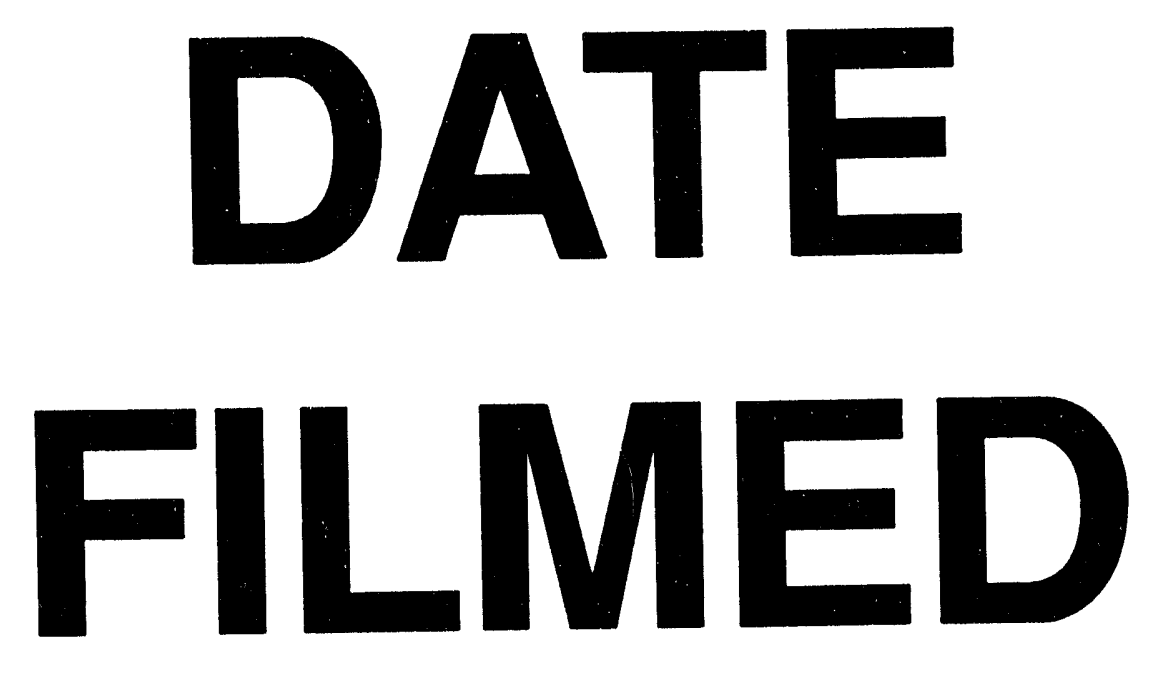

$6 / 29 / 94$
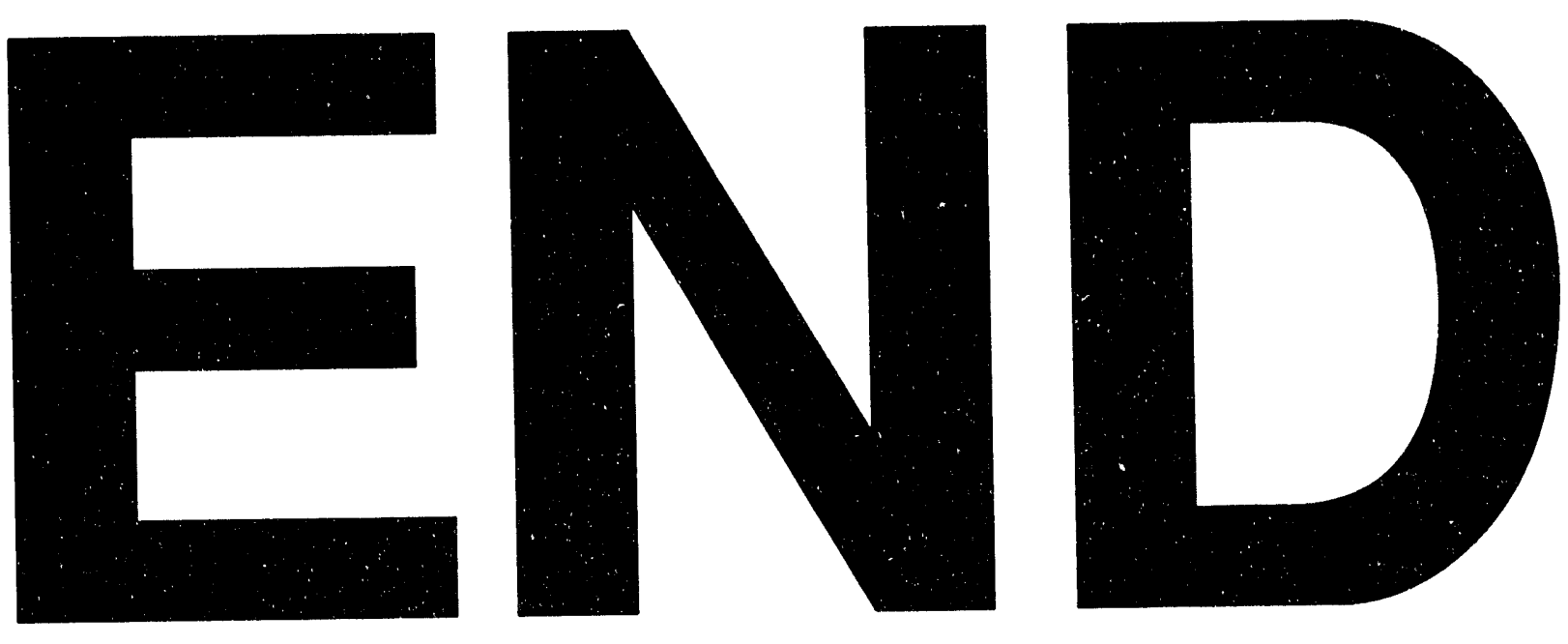
